Trinity University

Digital Commons @ Trinity

$9-2021$

\title{
Detrital Zircon Record of Magmatism and Sediment Dispersal Across the North American Cordilleran Arc System $\left(28^{\left.-48^{\circ} \mathrm{N}\right)}\right.$
}

\author{
T. M. Schwartz \\ Kathleen D. Surpless \\ Trinity University, ksurples@trinity.edu \\ J. P. Colgan \\ S. A. Johnstone \\ C. S. Holm-Denoma
}

Follow this and additional works at: https://digitalcommons.trinity.edu/geo_faculty

Part of the Earth Sciences Commons

\section{Repository Citation}

Schwartz, T. M., Surpless, K. D., Colgan, J. P., Johnstone, S. A., \& Holm-Denoma, C. S. (2021). Detrital zircon record of magmatism and sediment dispersal across the North American Cordilleran arc system $\left(28-48^{\circ} \mathrm{N}\right)$. Earth-Science Reviews, 220, Article 103734. https://doi.org/10.1016/j.earscirev.2021.103734

This Article is brought to you for free and open access by the Geosciences Department at Digital Commons @ Trinity. It has been accepted for inclusion in Geosciences Faculty Research by an authorized administrator of Digital Commons@ Trinity. For more information, please contact jcostanz@trinity.edu. 
Invited Review

\title{
Detrital zircon record of magmatism and sediment dispersal across the North American Cordilleran arc system $\left(28-48^{\circ} \mathrm{N}\right)$
}

\author{
Theresa M. Schwartz ${ }^{\text {a, }}$, Kathleen D. Surpless ${ }^{b}$, Joseph P. Colgan ${ }^{\text {a }}$, Samuel A. Johnstone ${ }^{\text {a }}$, \\ Christopher S. Holm-Denoma ${ }^{c}$
}

${ }^{a}$ U.S. Geological Survey, Geosciences \& Environmental Change Science Center, Denver, CO, United States of America

${ }^{\mathrm{b}}$ Trinity University, Geosciences Department, San Antonio, TX, United States of America

${ }^{\mathrm{c}}$ U.S. Geological Survey, Geology, Geophysics, and Geochemistry Science Center, Denver, CO, United States of America

\section{A R T I C L E I N F O}

\section{Keywords:}

sediment provenance

source-to-sink

paleogeography

magmatic arc

forearc basin

foreland basin

\begin{abstract}
A B S T R A C T
As zircon U-Pb geochronology has become a leading method in sediment provenance studies and basin analysis over the past 20 years, the volume of detrital zircon data made available in published literature has enabled researchers to go beyond source-to-sink provenance studies to explore increasingly complex geologic problems. In this review, we utilize the growing body of detrital zircon data acquired from Jurassic-Paleocene forearc and foreland basin strata of the North American Cordillera to investigate the Mesozoic to earliest Cenozoic evolution of the arc and its associated basins between $28^{\circ} \mathrm{N}$ and $48^{\circ} \mathrm{N}$. Our compilation includes 830 detrital zircon samples (101,898 individual ages) from 70 studies published between 2000 and 2020 . For comparative purposes, we also compile 1307 igneous zircon $\mathrm{U}-\mathrm{Pb}$ ages that characterize the magmatic history of the arc. We place primary emphasis on detrital zircon ages between 251 and 56 Ma that we infer to be uniquely derived from magmatic sources in the arc. Informed by existing knowledge of magmatic, structural, and sedimentological processes that acted on the orogen, we investigate spatial and temporal trends in these "arc-derived zircon" to establish a detrital record of arc magmatism, investigate source-to-sink relationships between the arc and adjacent basins, and discuss controls on sediment dispersal across the orogen.

Our review shows that compilations of detrital zircon data from the Cordilleran forearc and foreland basin systems are excellent proxies for arc magmatism because the basins are enriched in arc-derived zircon and compilations provide space- and time-integrated records of crystallization ages. The compiled detrital zircon data support a history of continuous arc magmatism throughout Mesozoic and earliest Cenozoic time, characterized by low-volume magmatism from Triassic-Early Jurassic time $(\sim 251-174 \mathrm{Ma})$ and episodic higher-volume magmatism from Middle Jurassic-Late Cretaceous time ( $\sim 174-66 \mathrm{Ma})$. These trends elucidate the initiation and timing of magmatic events at the orogen-scale and corroborate our understanding of cyclic arc behavior.

Detrital zircon distributions are spatially and temporally variable both within and across basins, which we discuss relative to topographic development of the orogen and attendant responses of sediment dispersal systems. Detrital zircon distributions in the forearc signal rapid transfer of sediment from the arc to basins dominantly via fluvial processes. In contrast, detrital zircon distributions across the foreland reflect the presence of topographic barriers in the hinterland region of the arc that effectively isolated parts of the foreland. The presence of hinterland topography in turn highlights the important role of ash-fall events in delivering arc-derived zircon to the foreland, underscoring the need to consider ash-fall processes in paleodrainage reconstructions. These broad regional trends, and in general the close linkage between orogenic process and sediment dispersal, emerge from our compilation because it averages out much of the local variability observed in studies of more limited geographic or temporal extent.
\end{abstract}

\footnotetext{
* Corresponding author.

E-mail address: tmschwartz@usgs.gov (T.M. Schwartz).
} 


\section{Introduction}

The use of sediment provenance datasets to elucidate tectonic processes and basin histories is rooted in over 50 years of research, beginning with the petrographic classification of sandstones using descriptive, composition-based terms (e.g., Folk, 1974; with updated approaches by Weltje, 2006; Garzanti, 2019) and the relation of sandstone modal compositions to tectonic setting (e.g., Dickinson and Suczek, 1979; Dickinson et al., 1983). Modal compositions, typically defined using the relative proportions of quartz, feldspar, and lithic grains (QFL) in a sandstone sample, are ultimately governed by plate tectonics, where basins receive sediment from associated uplifted terranes (Dickinson and Suczek, 1979; Dickinson et al., 1983). Forearc basins commonly contain lithofeldspathic and feldspathic sands derived from adjacent magmatic arcs, with primary sources being the volcanic carapace of the arc and underlying granitic plutons. Retroarc foreland basins, on the other hand, commonly contain lithic to quartzose sands derived from sedimentary and subordinate volcanic rocks that were uplifted in the fold-thrust belt, with relatively minor input from the arc itself.

In recent decades, the "detrital zircon revolution" (Gehrels, 2012) has brought a new perspective to sediment provenance studies, prompting significant advances in understanding plate tectonic processes, source-to-sink relationships, and basin evolution. The physicochemical resistance of detrital zircon grains to weathering, transport, and even tectonic and magmatic recycling has made them an important mineral phase in sediment provenance studies (Hawkesworth et al., 2010; Cawood et al., 2012). Technological improvements in acquiring detrital zircon U-Pb dates by laser ablation-inductively coupled plasmamass spectrometry (LA-ICP-MS) have enabled acquisition of increased numbers of zircon ages at lower cost (Gehrels, 2014), prompting a nearexponential increase in the number of detrital zircon ages acquired between ca. 1990 and today (after Sharman et al., 2018a, their Fig. 1). As more detrital zircon data are produced, synthesis of new data with existing datasets has allowed workers to go beyond simple source-tosink provenance studies and explore the integrated evolution of orogenic, erosion, and sediment transport systems (e.g., LaMaskin, 2012).

Prior work that has investigated igneous and detrital zircon age distributions for granitoid crustal terranes and their associated basins has shown that the two are characterized by similar age peak and trough patterns (Condie et al., 2009), suggesting that detrital zircon distributions may be a valid record of magmatism on geologic time scales (Hawkesworth et al., 2010). However, it is worth noting that igneous age peaks do not always have detrital counterparts, and vice versa (Condie et al., 2009), due to processes such as tectonic or magmatic overprinting, the removal of crustal sources by erosion, inadequate sampling, or the masking of small age peaks by larger ones in detrital spectra (e.g., Condie et al., 2009; Cawood et al., 2012; Barth et al., 2013; Gaschnig et al., 2016). Thus, the pairing of available igneous and detrital zircon ages provides a more complete, yet longer-term and timeaveraged, understanding of the evolution of magmatic systems (e.g., Barth et al., 2013; Riggs et al., 2013; Surpless et al., 2019).

Once established, cyclical behavior of Cordilleran systems may involve regional shortening, basin development, local crustal extension, widespread intermediate to silicic magmatism, and regional and/or contact metamorphism (DeCelles et al., 2009). In these cycles, batholiths are constructed through magmatic high flux events (HFEs) that generate up to $75-80 \%$ of the arc mass within periods of $10-15 \mathrm{Myr}$, between which magmatic lulls of 25-50 Myr may occur (Ducea, 2001; DeCelles et al., 2009; Ducea et al., 2015a). HFEs may then be closely followed by the foundering of arc roots (Ducea and Barton, 2007; Ducea et al., 2015b), which prompts isostatically driven surface uplift of the arc and hinterland (DeCelles et al., 2009) and a sedimentary response in associated Cordilleran basins (DeCelles and Graham, 2015). Resulting arc-related detrital zircon distributions in sedimentary basins are controlled by the volume, chemical composition, and temperature of magma generated in the arc; the preservation potentials of intrusive rocks and their extrusive equivalents; the efficiency and frequency with which arc-derived zircon becomes sediment and is transported to basins; and the relative abundance of non-arc detrital zircons in the resulting sediment (after Watson and Harrison, 1983; Cawood et al., 2012; LaMaskin, 2012).

The growing body of in situ and detrital zircon U-Pb data collected from the North American Cordillera provides an opportunity to assess the Mesozoic to early Cenozoic evolution of the Cordilleran arc and basins as a complete system. We compile in situ $(n=1307)$ and detrital zircon ( $n=101,898) \mathrm{U}-\mathrm{Pb}$ ages from the Cordilleran magmatic arc and adjacent basins between $\sim 28-48^{\circ} \mathrm{N}$ to investigate the Jurassic to Paleocene history of arc magmatism, topographic growth, and sedimentation. Whereas pre-Mesozoic zircon grains are ubiquitous throughout the stratigraphy of western North America (e.g., Schwartz et al., 2019b), detrital zircon grains with ages $\sim 251-56$ Ma can be uniquely associated with the Cordilleran arc, and in many cases, their presence reflects first-cycle derivation. We focus specifically on the abundance of arc-derived zircon in Cordilleran basins and use our compilation of $>100,000$ detrital zircon ages to review what is known about the evolution of the Cordilleran magmatic arc, its associated deformation belts, and its associated forearc and foreland basins.

\section{Geologic context}

\subsection{Tectonic overview: Mesozoic-early Cenozoic building of the North American Cordillera}

The Mesozoic to early Cenozoic North American Cordillera and its associated basins (Fig. 1) developed in response to a protracted history of ocean-continent plate convergence, oceanic plate subduction, and terrane accretion. The orogen developed along the western edge of North America at the boundary between Archean-Paleoproterozoic North American crust (e.g., Whitmeyer and Karlstrom, 2007; Lund et al., 2015) and a series of allochthons, a crustal boundary defined today by the ${ }^{87} \mathrm{Sr} /{ }^{86} \mathrm{Sr}=0.706$ isopleth (Fig. 1; Kistler and Peterman, 1978). Allochthonous terranes include Paleozoic peri-cratonic rocks of North American affinity that were accreted prior to development of the orogen (e.g., the Roberts Mountains and Golconda allochthons, respectively accreted during the Devonian-Mississippian Antler and PermianTriassic Sonoma orogenies; Nilsen and Stewart, 1980; Oldow, 1983; Oldow et al., 1990; Poole et al., 1992; Burchfiel et al., 1992; Wyld, 2002) and Paleozoic-Mesozoic arc and ophiolitic rocks that were accreted during Jurassic-Cretaceous development of the orogen (e.g., the Sierra Foothills, Klamath Mountains, Blue Mountains, Intermontane and Insular terranes; Monger et al., 1982; Rusmore et al., 1988; Oldow et al., 1989; McClelland et al., 2000; Dickinson, 2004; Ernst et al., 2008; Gehrels et al., 2009).

Protracted plate convergence and deformation along the continental margin resulted in the generation of a magmatic arc, forearc and hinterland deformation belts, and long-lived forearc and foreland basin systems on the flanks of the orogen (e.g., Fig. 2). During this time, the character of plate convergence and resultant deformation responded to variations in plate motions and the nature of subducting oceanic lithosphere (summarized from Yonkee and Weil, 2015). Relative motions between the North American plate and subducting oceanic lithosphere were generally orthogonal during Middle Jurassic time and changed to sinistral-oblique during latest Jurassic and Early Cretaceous time. The direction of relative plate motion then changed to southwest-northeast in Late Cretaceous time, with dextral-oblique convergence characterizing much of the plate margin.

In the forearc region, Late Cretaceous dextral-oblique convergence resulted in transpression and strike-slip transport of rocks composing outboard accreted terranes, forearc depocenters, and parts of the magmatic arc. The magnitude of strike-slip transport of forearc terranes remains controversial: crustal fragments currently located in western 


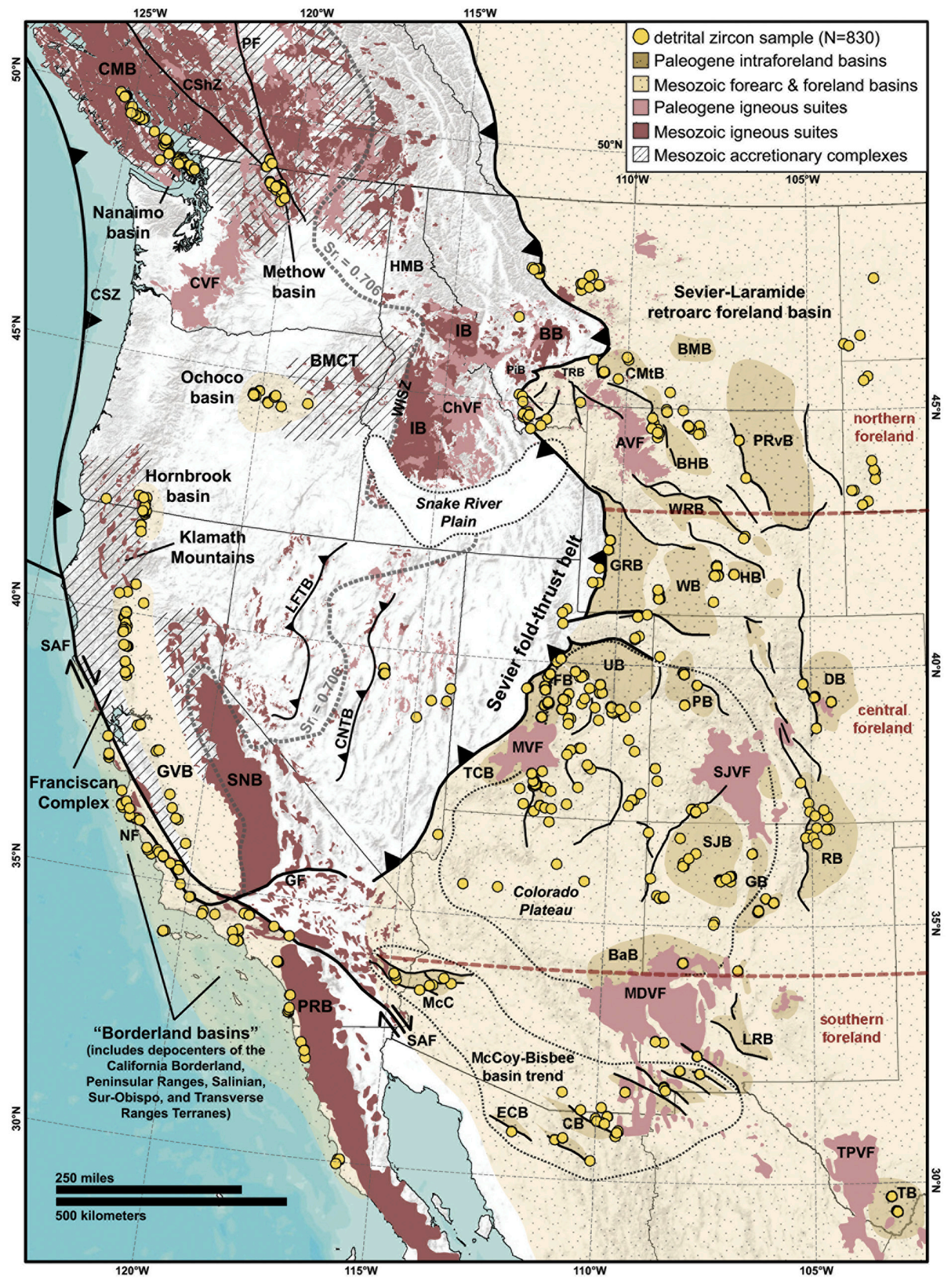

(caption on next page) 


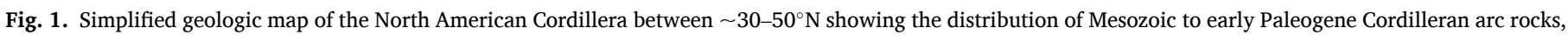

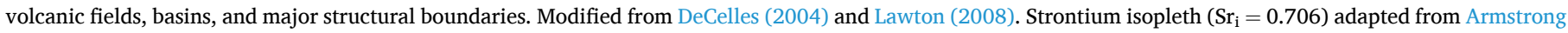

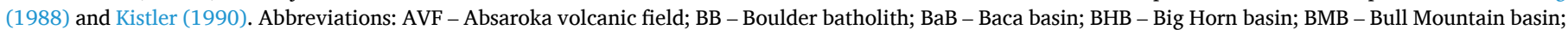

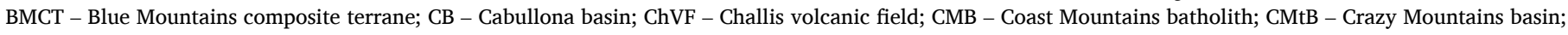

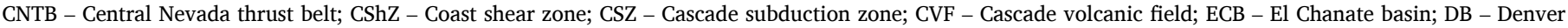

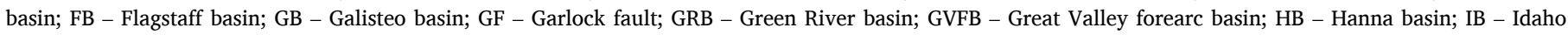

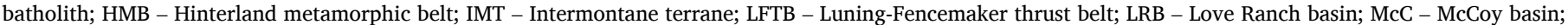

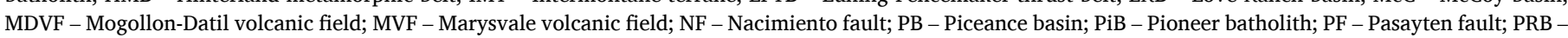

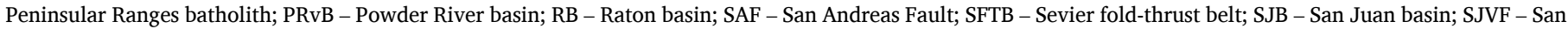

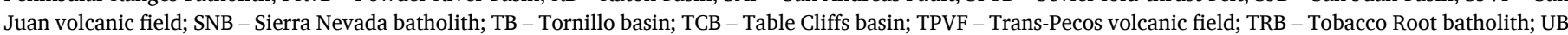

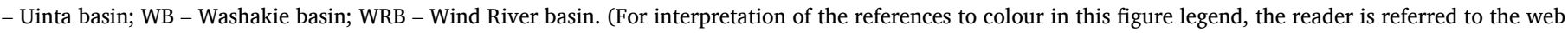
version of this article.)

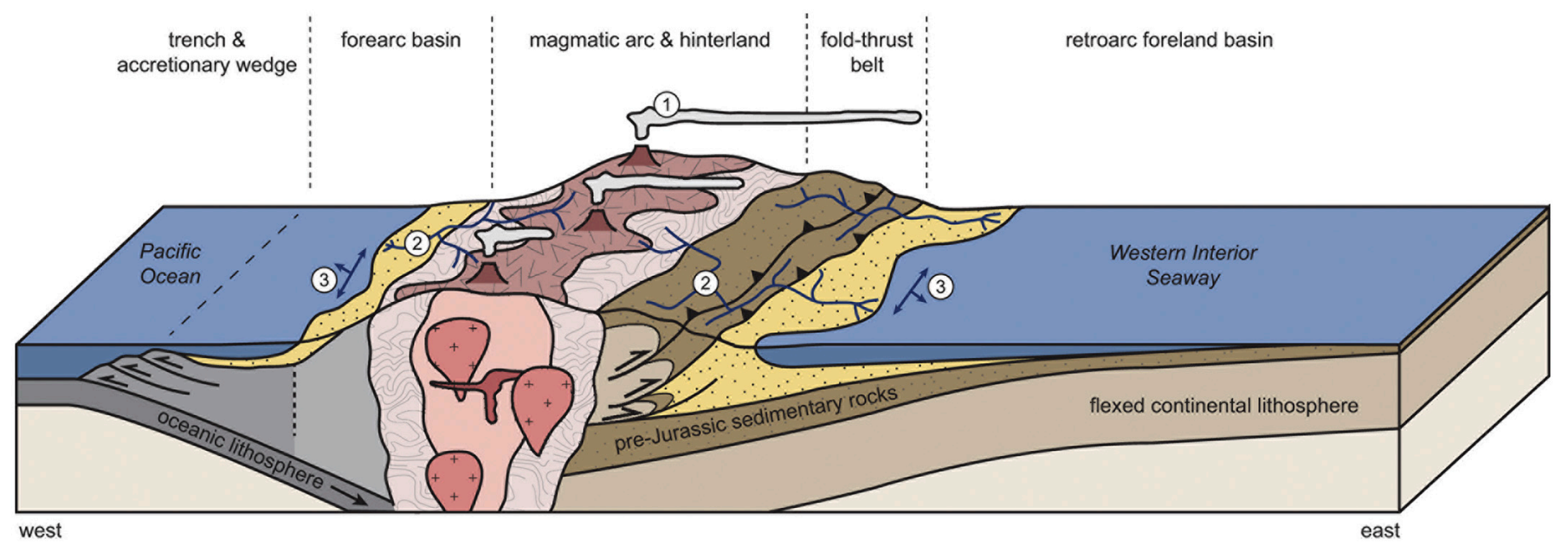

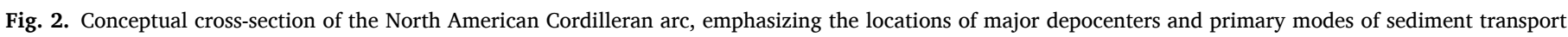

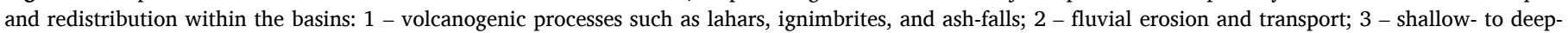
marine processes. Diagram inspired by Fosdick et al. (2014), their Fig. 14.

Canada, including the Methow and Nanaimo forearc basins (now located between $\sim 48-50^{\circ} \mathrm{N}$; Fig. 1), were translated northward during the Late Cretaceous and early Cenozoic, with estimates of translation ranging from $<1000 \mathrm{~km}$ (based on known and hypothesized dextral offset of faults in Oregon and northern California; Wyld et al., 2006) to $>2000 \mathrm{~km}$ (based on paleomagnetic signatures of rocks in the Canadian sector of the Cordillera; Irving et al., 1995; Wynne et al., 1995; Kim and Kodama, 2004; Krijgsman and Tauxe, 2006; Rusmore et al., 2013). Notably, detrital zircon data have been used in multiple studies to address the extent of transport, with results both rejecting (Mahoney et al., 1999; DeGraaff-Surpless et al., 2003; LaMaskin et al., 2011; Surpless et al., 2014) and supporting (Housen and Beck Jr., 1999; Garver and Davidson, 2015; Matthews et al., 2017) longer-distance displacement of terranes. Herein, we prefer a model of moderate strike-slip displacement $(<1000 \mathrm{~km})$ when discussing histories of the Methow and Nanaimo forearc basins.

In addition to changes in relative plate motions, the degree of dip of the descending Farallon plate decreased along most of the plate margin during the Cretaceous, inferred from an eastward-shift in arc magmatism (Dickinson and Snyder, 1978; Lipman, 1992; Gehrels et al., 2009). Late Cretaceous shoaling of the Farallon plate resulted in the development of a flat-slab beneath the southern and central parts of the Cordillera, prompting intraforeland deformation of the Laramide orogeny. The initiation and duration of Laramide deformation was diachronous across the foreland region, beginning in southeast California ca. $90 \mathrm{Ma}$ and generally progressing northeastward into South Dakota through ca. 50 Ma (Copeland et al., 2017).

\subsection{Modern expression of the North American Cordillera $\left(28-48^{\circ} \mathrm{N}\right)$}

Between 28 and $48^{\circ} \mathrm{N}$, the Mesozoic to early Cenozoic North American Cordillera includes six major tectonic terranes, described here from west to east (Figs. 1, 2). The Franciscan accretionary belt, currently exposed in California and Oregon between $\sim 35-43^{\circ} \mathrm{N}$, is the remnant accretionary wedge that formed along the western margin of North America in Jurassic to early Cenozoic time (Dumitru et al., 2015; Wakabayashi, 2015). Immediately to the east lies a segmented forearc basin complex that is currently exposed between $\sim 29-52^{\circ} \mathrm{N}$; this includes the Great Valley basin of California, the Hornbrook basin of California-Oregon, the Ochoco basin of Oregon and the Methow and Nanaimo basins of Washington-British Columbia (Dickinson, 1992; Miller et al., 1992). The remnant Cordilleran arc lies east of the forearc region, geographically subdivided into the Peninsular Ranges batholith of Baja California $\left(\sim 28-34^{\circ} \mathrm{N}\right)$, the Sierra Nevada batholith of California-Nevada $\left(\sim 34-42^{\circ} \mathrm{N}\right)$, the Idaho-Boulder batholith complex of Idaho-Montana $\left(\sim 43-47^{\circ} \mathrm{N}\right)$, and the Coast Mountains batholith of British Columbia $\left(\sim 48-58^{\circ} \mathrm{N}\right)$. East of the arc, the Cordilleran hinterland metamorphic belt and Sevier fold-thrust belt extend from southern California $\left(\sim 35^{\circ} \mathrm{N}\right)$ through northern Canada $\left(\sim 60^{\circ} \mathrm{N}\right.$; DeCelles, 2004$)$. Notably, much of the hinterland metamorphic belt between $\sim 35-45^{\circ} \mathrm{N}$ has been overprinted by Cenozoic extension of the Basin and Range Province, resulting in net widening of the contractional terrane (e.g., Colgan and Henry, 2009; Long, 2019). The Sevier foreland basin lies immediately east of the fold-thrust belt between $\sim 35-60^{\circ} \mathrm{N}$ (after DeCelles, 2004), part of which (between $\sim 35-46^{\circ} \mathrm{N}$ ) was subsequently overprinted by the Laramide intraforeland province (after DeCelles, 2004; Copeland et al., 2017). 


\subsection{Source of first-cycle detrital zircon: Jurassic-Paleocene Cordilleran} $\operatorname{arc}$

Jurassic to Paleocene arc rocks, now largely exhumed to their batholithic roots (Figs. 1, 3a), record the prolonged subduction of paleoPacific ocean plates beneath the western margin of North America (Engebretson et al., 1985). The Peninsular Ranges, Sierra Nevada, Idaho-Boulder, and Coast Mountains batholiths (Figs. 1, 3a) are the four primary igneous components of the Mesozoic arc. We consider felsicintermediate igneous rocks that composed the arc as primary sources of first-cycle detrital zircon to adjacent Cordilleran basins, with lesser input by associated mafic units owing to their lower zircon content.

\subsubsection{Peninsular Ranges batholith $\left(\sim 28-34^{\circ} \mathrm{N}\right)$}

The Peninsular Ranges batholith is the southern segment of the oncecontinuous magmatic arc that stretched from the Sierra Nevada batholith of California to Baja California (Silver and Chappell, 1988; Premo et al., 2014). The northernmost part of the Peninsular Ranges batholith lies within the study region between $\sim 28-34^{\circ} \mathrm{N}$ (Figs. 1, 3a).

The Peninsular Ranges batholith is commonly subdivided into western and eastern components based on lithology and age (Silver and Chappell, 1988). The batholith ranges widely in composition from gabbro to granite with tonalite being volumetrically dominant (Silver and Chappell, 1988). The western segment has a heterogeneous composition composed of ocean island arc-type rocks that were accreted onto the North American continental margin, whereas the eastern segment is characterized by continental arc-type rocks that intruded Paleozoic and older metasediments (Gastil, 1975; Todd and Shaw, 1985; Gromet and Silver, 1987; Silver and Chappell, 1988; Bateman, 1992; Premo et al., 2014). In the northern Peninsular Ranges batholith, crystallization ages of intermediate-composition plutons decrease in age from west-to-east (Premo et al., 2014). Mirroring this age trend is an eastward progression toward more evolved chemical signatures (Silver and Chappell, 1988). The most voluminous phase of magmatism is interpreted to have occurred during middle Cretaceous time along the length of the Peninsular Ranges batholith, resulting in a HFE at ca.
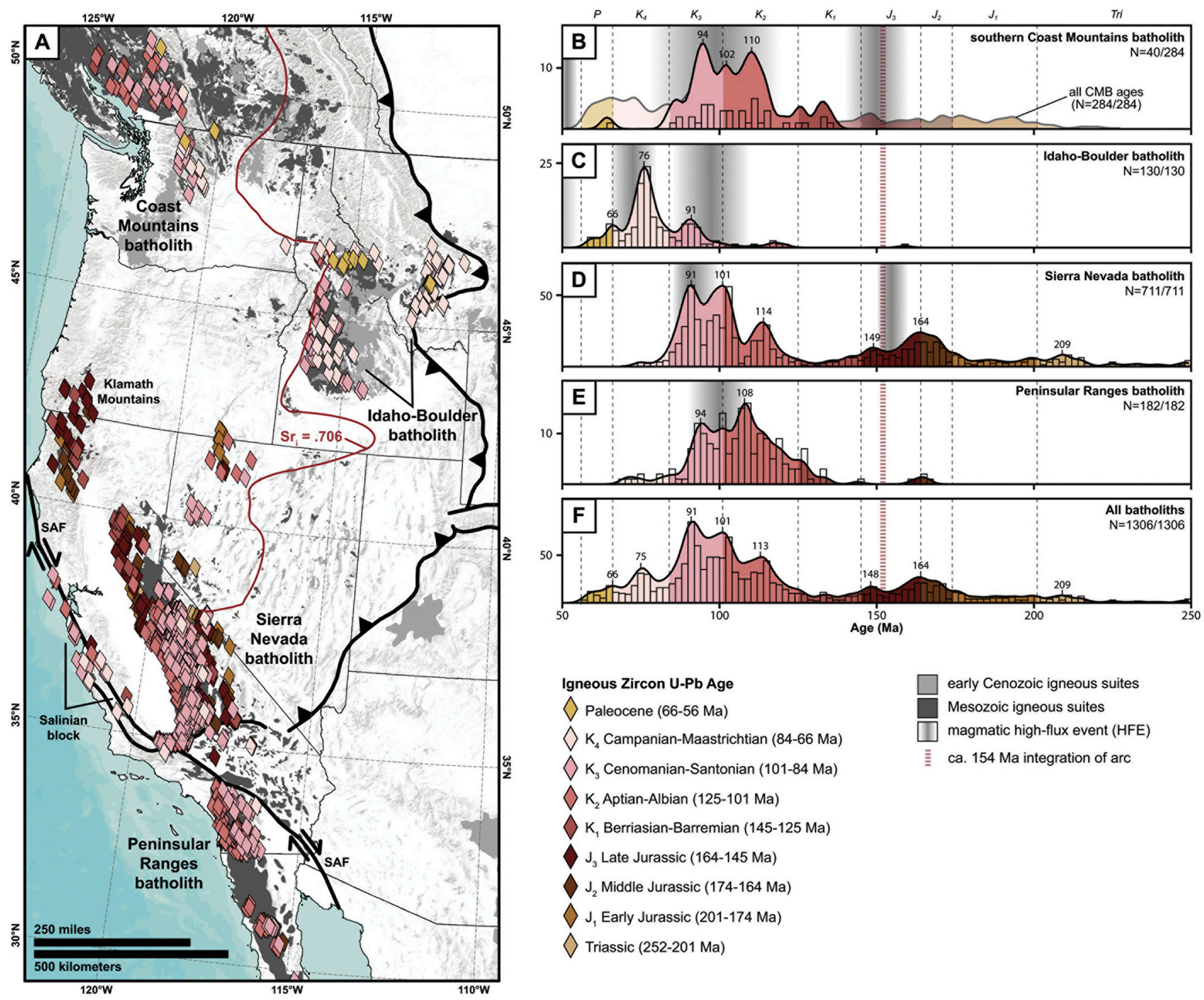

early Cenozoic igneous suites

Mesozoic igneous suites

magmatic high-flux event (HFE)

ca. $154 \mathrm{Ma}$ integration of arc

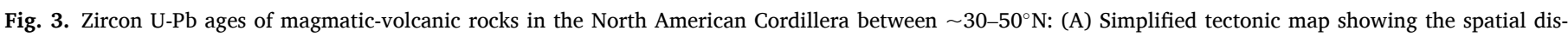

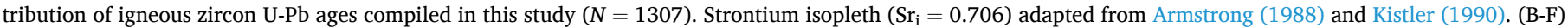

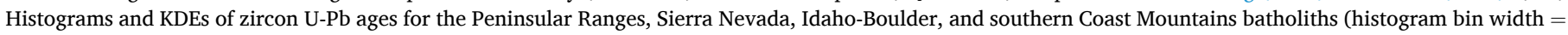

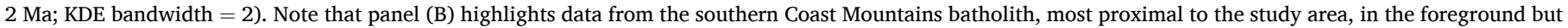
includes additional data from northern localities in the background. 
110-90 Ma (Jiang and Lee, 2017), structural thickening of the arc, and subsequent exhumation of the orogenic core (Schmidt et al., 2014).

\subsubsection{Sierra Nevada batholith $\left(\sim 34-42^{\circ} \mathrm{N}\right)$}

Separated from the Peninsular Ranges batholith by the San Andreas Fault (Figs. 1, 3a), the Sierra Nevada batholith is perhaps the most thoroughly studied of the Cordilleran batholiths (e.g., Saleeby et al., 2007). The entirety of the approximately $600 \mathrm{~km}$-long, north-northwesttrending arc assemblage lies within the study region between $\sim 34-42^{\circ} \mathrm{N}$ (Figs. 1, 3a). Herein, we consider intrusions of the Klamath Mountains to be a northern extension of the Sierra Nevada batholith (e.g., Irwin, 2003). We also include Jurassic-Cretaceous plutons currently exposed in the Sevier hinterland as part of the greater Sierra Nevada complex (e.g., Barton, 1990). Mid-crustal levels of the southern Sierra Nevada and/or northern Peninsular Ranges batholith have been translated $\sim 320 \mathrm{~km}$ northwestward along the Cenozoic San Andreas-Garlock fault system, exposed today in the Salinian block of coastal California, juxtaposed against the Franciscan Complex (Fig. 1; Grove, 1993; Saleeby et al., 2007; Chapman et al., 2012).

The Sierra Nevada batholith formed during prolonged subduction of oceanic crust beneath the southwest edge of North America (Dickinson, 1981). The arc was continuously active for $>140$ Myr (between ca. 220-80 Ma), but most surface and shallow crustal magmatism occurred during two short-lived HFEs at ca. 160-150 Ma and 100-85 Ma (Evernden and Kistler, 1970; Ducea, 2001; Ducea and Barton, 2007; DeCelles et al., 2009; Paterson et al., 2011; Cecil et al., 2012), with an estimated $78 \%$ of the current magmatic volume emplaced during the latter event (Ducea, 2001). Cretaceous plutons intruded a framework of Neoproterozoic-Mesozoic strata, accreted terranes of oceanic affinity, and older Triassic-Jurassic plutons (Cecil et al., 2012; Chapman et al., 2012; Attia et al., 2020). Pluton compositions range widely from mafic to felsic, with tonalite and granodiorite the most volumetrically abundant lithologies (Saleeby, 1990; Ducea, 2001; Chapman et al., 2012). Similar to the Peninsular Ranges batholith, Cretaceous magmatic rocks in the Sierra Nevada batholith show a trend of eastward younging and increased continental affinity (Chapman et al., 2012).

\subsubsection{Idaho-Boulder batholith $\left(\sim 42-48^{\circ} \mathrm{N}\right)$}

The Idaho batholith complex, herein including the eastwardadjacent Boulder, Pioneer, and Tobacco Root batholiths and additional satellite plutons, is offset nearly $500 \mathrm{~km}$ inboard from the Peninsular Ranges-Sierra Nevada-Coast Mountains batholith trend (Figs. 1, 3a). The Idaho batholith proper is $\sim 375 \mathrm{~km}$ long and trends northward through central Idaho and parts of western Montana. The Boulder, Pioneer, and Tobacco Root batholiths lie east of the Idaho batholith, extending nearly $200 \mathrm{~km}$ farther eastward into the Cordilleran foreland region of Montana (Fig. 1).

Magmatism associated with emplacement of the Idaho batholith marks a substantial northeastward shift in the locus of Cordilleran arc magmatism in Late Cretaceous time (Copeland et al., 2017), attributed to the presence of a relict Proterozoic crustal embayment on the margin of the North American continent (Lund, 2008; Schmandt and Humpreys, 2011; Yonkee and Weil, 2015). Unlike its counterparts, Idaho batholith magmatism was initially driven by subduction between ca. 110-87 Ma, but later resulted from crustal thickening and attendant melting at ca. 83-54 Ma, followed by extensional collapse of over-thickened crust at ca. 54-43 Ma (Gaschnig et al., 2011). Plutons of the Idaho batholith proper were emplaced into Paleoproterozoic continental crust and Meso-Neoproterozoic metasediments that lay east of the $\mathrm{Sr}_{\mathrm{i}}=0.706$ isopleth (e.g., Figs. 1, 3a; Unruh et al., 2008; Gaschnig et al., 2011, 2016). The bulk of the Idaho batholith consists of diorite, granodiorite, tonalite, and granite, but the oldest and youngest intrusive suites are compositionally diverse (Gaschnig et al., 2016).

The Boulder, Pioneer and Tobacco Root batholiths were emplaced into Archean-Paleoproterozoic continental crust and MesoproterozoicMesozoic strata (Hamilton and Myers, 1967; Robinson et al., 1968;
Klepper et al., 1971; Tilling, 1974). These batholiths intrude portions of the Sevier fold-thrust belt and multiple Laramide (basement-involved) uplifts of southwest Montana (Fig. 1; Kalakay et al., 2001; Lageson et al., 2001; Berger et al., 2011; Houston and Dilles, 2013; Scarberry et al., 2020). The Boulder batholith is the largest of the southwest Montana batholiths and is dominated by quartz monzonite, but also includes mafic and intermediate-composition plutons (Smedes, 1973; Lund et al., 2002; Scarberry et al., 2020). The batholith is uniquely associated with the remains of its volcanic carapace, recorded today by the Elkhorn Mountains Volcanics, which originally composed an extensive volcanic field up to $4.6 \mathrm{~km}$ thick (Klepper et al., 1957; Tilling et al., 1968; Lipman, 1984). The Pioneer and Tobacco Root batholiths are composed of diorite, granodiorite, tonalite, quartz monzonite, and granite (Hammarstrom, 1982; Mueller et al., 1996; Zen, 1996). Magmatism in both the Idaho batholith proper and the southwest Montana batholiths was largely nonmigratory, with successive phases of magmatism overprinting one another (Lund et al., 2002; du Bray et al., 2012; Gaschnig et al., 2016).

\subsubsection{Coast Mountains batholith $\left(\sim 48-61^{\circ} \mathrm{N}\right)$}

The Coast Mountains batholith is the longest continuous segment of the Cordilleran arc, extending for $>1700 \mathrm{~km}$ along the western margin of Canada (Fig. 1; Gehrels et al., 2009). The southernmost part of the Coast Mountains batholith lies within the northern part of the study region between $\sim 48-50^{\circ} \mathrm{N}$, along-strike of the Cenozoic Cascade Range of Washington and Oregon (Figs. 1, 3a).

The Coast Mountains batholith follows the continental-margin position of the Sierra Nevada and Peninsular Ranges batholiths and shares many characteristics of their emplacement histories. JurassicCretaceous magmatism was largely synchronous with that in the southern batholiths but remained active until ca. $50 \mathrm{Ma}$ (Gehrels et al., 2009), similar to the Idaho batholith. Igneous rocks range in composition from gabbro to leucogranite, with tonalite the most abundant lithology (Gehrels et al., 2009). The Coast Mountains batholith is subdivided into western and eastern belts that are separated by the early Paleogene Coast shear zone, which generally demarcates the boundary between the Insular and Intermontane superterranes (e.g., Rusmore et al., 2005; Gehrels et al., 2009).

Arc evolution was significantly complicated by episodes of terrane accretion and syn-magmatic lateral translation within the orogen (Monger et al., 1982; Butler et al., 2001). However, similar to the Sierra Nevada and Peninsular Ranges batholiths, magmatism migrated eastward across the central and southern Coast Mountains batholith complex between ca. 180-100 Ma (Friedman and Armstrong, 1995; Gehrels et al., 2009). Plutons were progressively emplaced into metasedimentary and volcanic rocks of the Insular and Intermontane superterranes between ca. 180-100 Ma, today showing west-to-east younging across terrane boundaries (Hill, 1985; van der Heyden, 1992; Friedman and Armstrong, 1995; Butler et al., 2006; Gehrels et al., 2009). Middle Cretaceous tectonic juxtaposition of the western and eastern belts resulted in the initiation of a single, west-facing magmatic arc (Friedman and Armstrong, 1995). Following this, 100-50 Ma plutons were emplaced across the width of the orogen (Gehrels et al., 2009), overprinting prior magmatic relations in the inboard accreted terranes (Friedman and Armstrong, 1995). HFEs are interpreted to have occurred ca. 160-140 Ma, 120-78 Ma, and 55-48 Ma based on geochronologic data from the central-northern Coast Mountains batholith (Gehrels et al., 2009; Girardi et al., 2012). The same HFEs are neither welldefined nor precluded in the southern Coast Mountains batholith, where available in situ U-Pb zircon data support the 120-78 Ma event (e. g., Friedman and Armstrong, 1995).

\subsection{Sinks of first-cycle detrital zircon: Cordilleran basins}

Jurassic to Paleocene strata are variably preserved within remnant forearc and foreland basins that lie adjacent to the Cordilleran arc. In 
this study, we define "forearc basin" as a depocenter that developed between the trench-accretionary prism and the Cordilleran arc, and "foreland basin" as a depocenter that developed in the retroarc region atop continental crust, adjacent to the Cordilleran fold-thrust belt (Fig. 2). Both preserved substantial volumes of sediment derived from the topographically prominent arc complex.

\subsubsection{Cordilleran forearc basins}

Our compilation includes detrital zircon data collected from six depocenters in the Cordilleran forearc region including the Great Valley, Hornbrook, Ochoco, Methow and Nanaimo forearc basins, as well as an area that we herein term "borderland basins" (Fig. 1). In general, substantial sediment deposition began in the forearc region in Late Jurassic time, persisting through the Cretaceous and into the Paleogene in some areas.

2.4.1.1. Great Valley basin. The Great Valley basin is the largest of the six forearc depocenters, located in California adjacent to the Sierra Nevada batholith between $\sim 36-41^{\circ} \mathrm{N}$ (Fig. 1). Its sedimentary fill is underlain by ophiolitic rocks (e.g., Godfrey et al., 1997) and unconformably onlaps terranes of the eastern Klamath Mountains in the north and terranes of the Sierran arc and associated foothills in the east (Harwood and Helley, 1987; Hosford Scheirer and Magoon, 2007). The Sacramento and San Joaquin basins form the northern and southern subbasins of the Great Valley forearc basin.

Deposition began in the Great Valley forearc in Late Jurassic time (Jones et al., 1969; Pessagno Jr., 1977), although the presence of Early Cretaceous detrital zircon ages in basal units indicate that much of the strata mapped as Upper Jurassic should instead be considered Lower Cretaceous (Surpless et al., 2006; Orme and Surpless, 2019). Throughout Cretaceous time, the Great Valley basin widened into a broad, bathyal forearc basin that hosted an extensive system of submarine fans (e.g., Dickinson and Rich, 1972; Dickinson and Seely, 1979; Ingersoll, 1979; Graham and Ingersoll, 1981; Suchecki, 1984). Latest Cretaceous and Paleogene shoaling of the basin resulted in the formation of a shelved basin (Dickinson et al., 1979a, 1979b) occupied by nonmarine environments in the Sacramento basin and marine environments in the San Joaquin basin (Dickinson, 1995). The sedimentary fill of the Great Valley basin is linked to sources in the Klamath-Sierra Nevada arc based on sandstone modal compositions and petrofacies, conglomerate clast compositions, detrital zircon age distributions, isotopic analysis, geochemical analysis, paleocurrent analysis, paleobathymetric trends, and seismic stratigraphy (Ojakangas, 1968; Dickinson and Rich, 1972; Ingersoll, 1979; Mansfield, 1979; Bertucci, 1983; Ingersoll, 1983; Seiders, 1983; Suchecki, 1984; Haggart, 1986; Moxon, 1990; Short and Ingersoll, 1990; Linn et al., 1991; Williams, 1997; Constenius et al., 2000; DeGraaff-Surpless et al., 2002; Surpless et al., 2006; Mitchell et al., 2010; van de Kamp and Leake, 2011; Cassel et al., 2012; Williams and Graham, 2013; Surpless, 2014; Martin and Clemens-Knott, 2015; Sharman et al., 2015; Orme and Surpless, 2019; Surpless et al., 2019).

2.4.1.2. Hornbrook basin. The Hornbrook basin is a relatively small forearc depocenter (e.g., Nilsen, 1984; Miller et al., 1992) located on the California-Oregon border at $\sim 42^{\circ} \mathrm{N}$, along-strike from the Great Valley forearc basin (Fig. 1). Its sedimentary fill, the Hornbrook Formation, unconformably rests on accreted terranes of the Klamath Mountains and is overlain by Oligocene and younger sedimentary and volcanic rocks of the Cascade Range (McKnight, 1971). Hornbrook Formation strata record a Cretaceous marine transgression during which late Albian deposition in fluvial and alluvial environments was followed by Late Cretaceous deepening to slope and deep basin plain environments (McKnight, 1971; Elliott, 1971; Nilsen, 1984, 1993). The Hornbrook Formation had sediment sources in the accreted terranes and plutons of the Klamath Mountains and the Sierra Nevada magmatic arc, as well as possible sources in northern Nevada and western Idaho (Surpless and
Beverly, 2013; Surpless, 2014).

2.4.1.3. Ochoco basin. The Ochoco basin is a relatively small forearc depocenter located in central Oregon at $\sim 44^{\circ} \mathrm{N}$, offset $\sim 200 \mathrm{~km}$ inboard from the Great Valley-Hornbrook basin trend (Fig. 1). The basin formed west of the Blue Mountains composite terrane and the Idaho-Boulder sector of the arc, north of the Sierra Nevada arc (Fig. 1), with interpreted sediment source areas in all three (Surpless and Gulliver, 2018). Ochoco basin strata overlie western units of the Blue Mountains composite terrane (Surpless and Gulliver, 2018) and are currently exposed as erosional remnants and inliers in central Oregon. Strata of the Mitchell Inlier were deposited in a submarine fan environment (Kleinhans et al., 1984; Little, 1986; Dorsey and Lenegan, 2007). Smaller exposures east of the Mitchell Inlier were deposited in fluvial (Goose Rock Conglomerate; Little, 1986), deltaic to shallow marine (Bernard Ranch Inlier; Dickinson and Vigrass, 1965; Dickinson et al., 1979a, 1979b; Little, 1986), and shallow marine (Antone Ranch, Dixie Butte, and Dayville Inliers; Thayer and Brown, 1966; Brooks et al., 1984; Little, 1986; Dorsey and Lenegan, 2007) environments.

Ammonites within the basal Mitchell Inlier are assigned an Albian age (McKnight, 1964; Jones et al., 1965; Kleinhans et al., 1984; P. Rodda, personal comm. reported in Dorsey and Lenegan, 2007), and ammonites and other mollusks within the eastern exposures indicate Albian to Cenomanian deposition (W. Stanton, pers. comm., reported in Merriam, 1901; Jones, 1960; Dickinson and Vigrass, 1965; Squires and Saul, 2002). Detrital zircon depositional age constraints for the Mitchell Inlier indicate a Coniacian maximum depositional age for much of the unit (Surpless and Gulliver, 2018), and Albian through Campanian strata documented in the subsurface (Thompson et al., 1984) indicate that Ochoco basin deposition continued through at least $83 \mathrm{Ma}$.

2.4.1.4. Methow basin. The Methow basin is located on the WashingtonBritish Columbia border at $\sim 48^{\circ} \mathrm{N}$, almost due north of the Ochoco basin (Fig. 1). Cretaceous strata of the Methow basin were deposited between the Insular and Intermontane superterranes (Kleinspehn, 1985; Garver, 1992; Garver and Brandon, 1994; Haugerud et al., 1996) in a forearc position relative to the Cordilleran magmatic arc (Monger et al., 1994; DeGraaff-Surpless et al., 2003; Gehrels et al., 2009). The latitude of the Methow basin has been modified by dextral translation along the Pasayten fault (e.g., Grieg, 1992; Hurlow, 1993), with estimates of displacement ranging from $<1000 \mathrm{~km}$ (e.g., Butler et al., 1989; Kodama and Ward, 2001; DeGraaff-Surpless et al., 2003; Surpless et al., 2014) to $>3000$ km (e.g., Wynne et al., 1995; Irving et al., 1996; Ward et al., 1997). Herein, we assume a moderate displacement of $<1000 \mathrm{~km}$ based on sediment provenance analyses and paleodispersal interpretations by DeGraaff-Surpless et al. (2003) and Surpless et al. (2014).

Lower Cretaceous strata of the Methow basin were deposited by west-directed submarine fans during the waning stages of an open marine environment in the southern basin (Coates, 1974; Tennyson and Cole, 1978; Kleinspehn, 1985) and by a large, shallow-water deltaic system in the northern basin (MacLaurin et al., 2011). Subsequent Upper Cretaceous strata were deposited in interfingering fluvio-deltaic environments derived from the east (Tennyson and Cole, 1978; Trexler Jr. and Bourgeois, 1985; Haugerud et al., 1996) and west (Tennyson and Cole, 1978; Trexler Jr. and Bourgeois, 1985). Fluvio-deltaic strata are in turn overlain by Upper Cretaceous braided fluvial deposits and volcanic rocks (Tennyson and Cole, 1978; Kiessling and Mahoney, 1997; Kiessling, 1998). Numerous studies of sediment provenance have documented plutonic and volcanic sources within a juvenile magmatic arc located to the east of the basin from middle Albian through at least Turonian (?) time (e.g., DeGraaff-Surpless et al., 2003; MacLaurin et al., 2011; Surpless et al., 2014).

2.4.1.5. Nanaimo basin. The Nanaimo basin is located due west of the Methow basin at $\sim 48^{\circ} \mathrm{N}$, on the Washington-British Columbia border 
and extending $\sim 160 \mathrm{~km}$ northwestward into British Columbia (Fig. 1). Upper Cretaceous to Paleogene strata of the Nanaimo basin unconformably rest on the Wrangellia terrane of the Insular superterrane (Greene et al., 2010) and plutonic rocks of the Coast Mountains batholith (Mustard, 1994). Based on different interpretations of the primary mechanism of subsidence, the Nanaimo basin has been interpreted as both a forearc basin (Muller and Jeletzky, 1970; England and Bustin, 1998; Matthews et al., 2017; Kent et al., 2019) and a foreland basin (Brandon et al., 1988; Mustard, 1994; Mustard et al., 1995). Due to its current forearc position relative to the Cordilleran arc, we nominally consider it to be a forearc basin. Similar to the Methow basin, the latitude of the Nanaimo basin has been modified by dextral translation along the continental margin with estimates of displacement ranging from $<1000 \mathrm{~km}$ (e.g., Wyld et al., 2006) to $>2000 \mathrm{~km}$ (e.g., Irving et al., 1995; Wynne et al., 1995; Kim and Kodama, 2004; Krijgsman and Tauxe, 2006; Rusmore et al., 2013).

Throughout Late Cretaceous time, strata of the Nanaimo basin were deposited in nonmarine to marginal-marine environments followed by deep-marine environments. Proximal sediment sources include the Coast Mountains batholith to the east, the Wrangellia terrane to the west, and the North Cascade fold-and-thrust belt to the south (e.g., Mustard et al., 1995; Katnick and Mustard, 2003; Brown, 2012; Matthews et al., 2017; Coutts et al., 2020), with additional distal sediment sources that are debated based on the inferred Late Cretaceous paleolatitude of the basin relative to North America (e.g., Matthews et al., 2017).

2.4.1.6. "Borderland basins". In this study, we informally assign the name "borderland basins" to the Upper Cretaceous-Paleocene sedimentary successions that lie to the west of the Peninsular Ranges batholith and San Andreas Fault (Fig. 1), many of which have been displaced up to $\sim 350 \mathrm{~km}$ northwestward from their original locations by late Cenozoic dextral offset along the San Andreas and Nacimiento faults (Graham et al., 1989; Grove, 1993; Jacobson et al., 2011; Sharman et al., 2015). These include sediments associated with the Peninsular Ranges, Sur-Obispo, California Borderland, Transverse Ranges, and Salinian terranes that were deposited in fan delta and submarine fan environments in the forearc region (e.g., Grove, 1993). Previous sediment provenance work suggests variable sediment sources including local crystalline basement, Cordilleran arc rocks, and various lithologies in the Mojave Desert region (Grove, 1993; Jacobson et al., 2011; Sharman et al., 2015).

\subsubsection{The Cordilleran foreland basin}

Late Jurassic tectonic consolidation of the Cordilleran orogen prompted the development of a laterally continuous, north-south trending retroarc deformation belt and foreland basin complex (Fig. 1). Immediately east of the arc, the Cordilleran hinterland varies greatly in width along strike of the orogen, being widest in what is now Nevada. In eastern Nevada and western Utah, the hinterland is composed of Neoproterozoic to Triassic shelf strata autochthonous to North America, which are structurally overlain in central and western Nevada by a series of late Paleozoic to early Mesozoic allochthons composed of highly deformed marine sediments (e.g., Burchfiel et al., 1992). Scattered Jurassic and Cretaceous plutons were emplaced throughout the hinterland coeval with magmatism in the Sierra Nevada arc to the west (e.g., Barton and Hanson, 1989). The hinterland region is bordered on the east by the Sevier fold-thrust belt, which is subdivided into western and eastern belts that record remarkably consistent histories along strike of the orogen (DeCelles, 2004). The western belt includes mega-thrust sheets of Proterozoic-Paleozoic strata emplaced during Early Cretaceous time (ca. 142-90 Ma), whereas the eastern belt is composed of smaller, more closely spaced thrust sheets of PaleozoicMesozoic strata emplaced during Late Cretaceous-Paleocene time (ca. 86-55 Ma; DeCelles and Graham, 2015). The foreland basin system, coupled to the fold-thrust belt, chronicles the onset of Cordilleran orogenesis, emplacement of the fold-thrust belt, and prolonged deposition in various depositional environments. Although sedimentation occurred in the incipient foreland region prior to Late Jurassic time, Upper Jurassic strata are commonly considered to record the initiation of the Cordilleran foreland basin (e.g., DeCelles, 2004 and references within). Deposition persisted through the Paleogene, with latitudinal variations in basin geometry, depositional environments, and sediment source areas (e.g., see compilations by Robinson Roberts and Kirschbaum, 1995; DeCelles, 2004; Yonkee and Weil, 2015).

2.4.2.1. Southern foreland basin $\left(\sim 28-34^{\circ} N\right)$. The southern foreland region between $\sim 28-34^{\circ} \mathrm{N}$ (Fig. 1) encompasses Jurassic-Paleocene deposits preserved in relict basins as erosional remnants and inliers in the southern Basin and Range Province, located south of the Colorado Plateau and extending southeastward from California along the United States-Mexico border into west Texas. These deposits include remnants of the Late Jurassic-Cretaceous McCoy and Bisbee basins as well as Late Cretaceous-Paleogene Laramide basins. Deposits of the southern foreland region, as defined herein, preserve a unique tectonic and depositional history compared to their northern equivalents.

The Bisbee basin and its counterparts are remnants of a Border rift system that developed in response to Middle Jurassic intracontinental rifting that extended northwestward from the Gulf of Mexico toward southern California (Bilodeau, 1982; Dickinson and Lawton, 2001), inferred to be associated with slab rollback beneath the Cordilleran arc (Lawton and McMillan, 1999). Middle Jurassic backarc rifting generated a string of extensional basins along the trend of the rift, bound to the north-northeast by the Mogollon highlands that were uplifted as the northern rift shoulder (Bilodeau, 1986; Lawton et al., 2020). Uplift of the Mogollon highlands isolated Border rift depocenters from ageequivalent foreland basins to the north for much of their history, at least through the middle Aptian (e.g., Lawton et al., 2020). The origin of the correlative McCoy basin, located at the California-Arizona border, remains enigmatic; the basin has been considered to be the northwestern continuation of the Border rift system (e.g., Dickinson and Lawton, 2001; Spencer et al., 2011) and a retroarc foreland basin that formed east of the Cordilleran arc (Barth et al., 2004). Late CretaceousPaleogene Laramide deformation reactivated structural boundaries and obscured genetic relationships between earlier depocenters (forming "inversion-flank" basins; Lawton, 2008). Laramide deformation also resulted in the formation of the Tornillo basin on the west Texas-Mexico border (Lehman, 1991), east of the classically defined Laramide province.

Thick successions of Jurassic volcanic assemblages in the Border rift system record the onset of rift magmatism in the southern foreland region (Dickinson and Lawton, 2001). As components of a northwestoriented rift basin complex that emanated from the Gulf of Mexico, the Jurassic Bisbee basin and its counterparts were inundated from the southeast, resulting in progressively shallower environments toward the northwest, with the Bisbee basin hosting mixed terrestrial and marine environments (Dickinson and Lawton, 2001). Subsequently, the Early Cretaceous Bisbee basin was dominated by terrestrial environments, and was then variably inundated by the Western Interior Seaway from the middle Aptian through the Late Cretaceous (Lawton et al., 2020). The coeval McCoy basin was exclusively nonmarine throughout its history (Dickinson and Lawton, 2001; Barth et al., 2004; Lawton et al., 2020), as were the Laramide inversion-flank basins that succeeded the McCoy and Bisbee basin systems (Lawton, 2008).

2.4.2.2. Central foreland basin $\left(\sim 34-43^{\circ} N\right)$. The central foreland region between $\sim 34-43^{\circ} \mathrm{N}$, commonly considered the retroarc counterpart to the Great Valley forearc basin of California (e.g., DeCelles and Graham, 2015; Yonkee and Weil, 2015), is perhaps the most thoroughly studied part of the foreland with regard to its tectonic, structural, and 
sedimentological evolution. As defined herein, this region encompasses Jurassic-Paleocene deposits preserved within and surrounding the Colorado Plateau, extending eastward to the Rocky Mountain front range of New Mexico-Colorado, and northward into central Wyoming (Fig. 1).

Between ca. 155 and $55 \mathrm{Ma}$, crustal shortening at this latitude propagated approximately $1000 \mathrm{~km}$ eastward from the Nevada hinterland into the North American craton (DeCelles, 2004, and references within), spurring the development of a coupled fold-thrust belt and foreland basin (e.g., DeCelles and Giles, 1996). Thin-skinned deformation and development of the Sevier fold-thrust belt largely coincided with high-flux arc magmatism recorded by the Sierra Nevada batholith (DeCelles and Graham, 2015). Beginning ca. 80 Ma, deformation transferred into the foreland basin as basement-involved (thick-skinned) Laramide structures diachronously inverted the Sevier foreland (DeCelles, 2004; Copeland et al., 2017). Laramide deformation at this latitude was largely amagmatic (e.g., Dickinson and Snyder, 1978) except for focused volcanism in the Colorado mineral belt (Stein and Crock, 1990; Chapin, 2012).

During Late Jurassic and throughout most of Early Cretaceous (early Albian) time, the central foreland was characterized by terrestrial environments that generally transported sediment eastward into the foreland basin from orogenic highlands located to the west (Robinson Roberts and Kirschbaum, 1995; DeCelles, 2004; Yonkee and Weil, 2015). Beginning ca. $110 \mathrm{Ma}$, the foreland was inundated by the Western Interior Seaway and remained a marine foreland basin through most of Late Cretaceous time (Robinson Roberts and Kirschbaum, 1995; DeCelles, 2004; Yonkee and Weil, 2015). During this time, terrestrial environments in areas proximal to the fold-thrust belt transitioned eastward into marginal, shallow, and deeper marine environments associated with the seaway; the positioning of the various environments varied as shorelines responded to fluctuations in relative sea level (e.g., Robinson Roberts and Kirschbaum, 1995). Regression of the Western Interior Seaway began ca. $75 \mathrm{Ma}$, closely associated with the initiation of Laramide intraforeland deformation (Copeland et al., 2017) and resulting in the resumption of terrestrial environments across the foreland. The proximal part of the central foreland hosted extensive lacustrine systems of the Uinta-Piceance and Greater Green River basins beginning in late Paleocene time (Lawton, 2008).

2.4.2.3. Northern foreland basin $\left(\sim 43-48^{\circ} \mathrm{N}\right)$. The northern foreland region between $\sim 43-48^{\circ} \mathrm{N}$ encompasses Jurassic-Paleocene deposits exposed between central Wyoming and northern Montana, extending eastward into the western parts of North and South Dakota (Fig. 1). Similar to the central foreland region, the northern foreland was affected by both thin-skinned deformation associated with growth of the Sevier fold-thrust belt and thick-skinned deformation associated with the emergence of Laramide intraforeland structures. However, timing in structural style was latitudinally variable across the northern foreland. In Wyoming, the sequence of thin-skinned thrusting followed by Laramide deformation largely paralleled that of the central foreland, with a Late Jurassic onset of shortening, Early-Late Cretaceous propagation of the Sevier fold-thrust belt, and latest Cretaceous onset of Laramide uplift (e.g., DeCelles, 2004; Weil and Yonkee, 2012; Fan and Carrapa, 2014). North of the Snake River Plain in Montana, thrusting also initiated in Late Jurassic time, but most shortening occurred between Late Cretaceous (mid-Campanian) and Eocene time (Schmidt and O'Neill, 1982; Harlan et al., 1988; Fuentes et al., 2009, 2012). In the Laramide province of southwestern Montana between $\sim 44-47^{\circ} \mathrm{N}$, the onset of thickskinned deformation began as early as ca. $100 \mathrm{Ma}$ and continued through 60 Ma (Schmidt and Garihan, 1983; Schwartz and DeCelles, 1988; Carrapa et al., 2019; Vuke, 2020). During this time, thin- and thick-skinned structures interacted with one another in the proximal foreland, generating a structural "overlap zone" that exerted strong influence on basin evolution in that area (e.g., Kulik and Schmidt, 1988; Schmidt et al., 1988; Vuke, 2020). Overlapping deformation styles were coeval with emplacement of the Idaho-Boulder batholith complex, parts of which intruded the fold-thrust belt and Laramide uplifts of southwestern Montana (e.g., Fig. 1; Kalakay et al., 2001; Lageson et al., 2001; Lund et al., 2002; Gaschnig et al., 2011).

Similar to the central foreland, the Late Jurassic through Early Cretaceous basin was characterized by terrestrial environments (dominantly fluvial) that generally drained eastward from orogenic highlands, with partial marine inundation of the foreland beginning ca. $115 \mathrm{Ma}$ (Schwartz and Vuke, 2019). The region was entirely inundated by the Western Interior Seaway beginning ca. $110 \mathrm{Ma}$, after which environments varied from terrestrial to marine through most of Late Cretaceous time (Robinson Roberts and Kirschbaum, 1995; DeCelles, 2004; Yonkee and Weil, 2015). Unlike many foreland regions to the south, construction of the Idaho-Boulder batholith and early emergence of Laramide structures in southwestern Montana generated a complex topography that exerted substantial control on sedimentary patterns in the proximal foreland (e.g., DeCelles, 1986; Schwartz and DeCelles, 1988). Following regression of the Western Interior Seaway ca. $75 \mathrm{Ma}$, environments remained terrestrial across the northern foreland.

\section{Methods \& approach}

We compile and compare zircon U-Pb ages from the Cordilleran magmatic arc and its associated forearc and foreland basins between $\sim 28-48^{\circ} \mathrm{N}$ (Fig. 1). "Arc-derived zircon" is defined herein as detrital zircon grains with ages 251-56 Ma that we assume are uniquely attributed to igneous sources within the North American Cordilleran arc. In this context, we consider the presence of arc-derived zircon in detrital samples to most commonly reflect first-cycle derivation from igneous sources in the arc, but we also acknowledge and discuss the potential for recycling of arc-derived zircon from older strata over the course of arc and basin evolution.

\subsection{Igneous zircon $U-P b$ age compilation}

We present a compilation of 1307 igneous U-Pb zircon ages of Triassic to Paleocene magmatic and volcanic rocks associated with the Cordilleran arc published in 129 previous studies (Supplemental Information, Table S1; Schwartz, 2021). Although a definitive magmatic arc was not established until the Late Jurassic (ca. 153-155 Ma; Dickinson et al., 1996; DeCelles, 2004; Surpless et al., 2006), we include earlier Mesozoic zircon ages $(\leq 251 \mathrm{Ma})$ to capture precursor magmatism associated with island arc accretion and volcanism. We note that prior workers, specifically those focused on the Sierra Nevada and Coast Mountains batholiths (e.g., Gehrels et al., 2009; Chapman et al., 2012), also included $\mathrm{U}-\mathrm{Pb}$ zircon ages $>251 \mathrm{Ma}$ in similar compilations. In addition, we acknowledge that previous detrital zircon studies focused on Permian-Triassic strata of the southwestern United States support an onset of Cordilleran magmatism as early as the late Permian (e.g., Riggs et al., 2013, 2016, 2020; Levy et al., 2020). However, we omit preMesozoic zircon U-Pb ages from our compilation 1) to simplify the timeline over which we analyze arc evolution and 2) because Pennsylvanian-Permian ( $\sim 350-250 \mathrm{Ma})$ zircon ages in the detrital record may also be attributed to sources in the Appalachian orogen (e.g., Gehrels et al., 2011) rather than the largely amagmatic Ancestral Rocky Mountain orogen (e.g., Leary et al., 2017) that preceded the Mesozoic Cordilleran arc. Likewise, we omit U-Pb zircon ages $<56 \mathrm{Ma}$ that have been documented in the northern batholiths and throughout the foreland province because they are more appropriately associated with Cenozoic magmatism in the continental interior, rather than the Cordilleran arc proper (e.g., Gehrels et al., 2009; Gaschnig et al., 2010).

The igneous $\mathrm{U}-\mathrm{Pb}$ ages are geographically subdivided into groups that represent modern exposures of the Peninsular Ranges, Sierra Nevada, Idaho-Boulder, and southern Coast Mountains batholiths and their closely associated magmatic/volcanic rocks. Groups of igneous ages are visualized as histograms and kernel density estimates (KDEs) 
using detritalPy (Sharman et al., 2018a), providing a geochronological "fingerprint" for each batholith segment (Fig. 3b-e). We strongly emphasize that the zircon fingerprints of each batholith segment only reveal apparent trends in arc activity due to inherent limitations and biases in the igneous zircon record: 1 ) The available igneous zircon ages presented herein are representative of arc rocks as they appear at the Earth's surface today. Progressive magmatic/volcanic overprinting within each batholith segment during the Mesozoic was variably followed by additional tectonic, structural, erosional, and/or volcanic modification of the batholiths. For these reasons, the spatial distributions of ages (Fig. 3a) and the relative proportions of ages (Fig. 3b-f) do not truly reflect the Mesozoic-early Cenozoic surface expression of the arc that would have provided detritus to adjacent basins. 2) Zircon ages from batholith rocks are heavily biased toward the most recent and/or most voluminous phases of magmatism, and thus underrepresent older and/or less voluminous phases of magmatism (e.g., Gehrels et al., 2009; Gaschnig et al., 2016). Accordingly, the relative proportions of younger $v s$ older zircon ages (Fig. 3b-f) may not truly reflect temporal variations in emplacement volumes or magmatic flux. 3) Finally, the observed distributions of dates in the cited studies are likely biased by preferential knowledge and study of certain areas (i.e., because of ease of access or prolonged research interest in certain plutons). Thus, the relative proportions of batholith ages (Fig. 3b-f) are also affected by spatial sample density. For these reasons, we simply use the zircon age distributions associated with each batholith segment to visualize crystallization histories, and do not attempt to make statistical comparisons between igneous and detrital data.

\subsection{Detrital zircon $\mathrm{U}-\mathrm{Pb}$ age compilation}

We present a compilation of 830 detrital zircon samples $(101,898$ individual detrital zircon ages) from 72 studies published between 2000 and 2020 (Supplemental Information, Table S2; Schwartz, 2021). The compilation includes samples collected from Jurassic to Paleocene strata that are preserved in remnant forearc and foreland basins of the Cordillera.

For the compilation and subsequent analyses, we utilized the ${ }^{206} \mathrm{~Pb} /{ }^{238} \mathrm{U}$ or ${ }^{207} \mathrm{~Pb} /{ }^{206} \mathrm{~Pb}$ "best ages" of zircon grains that were prescribed by original authors. Accordingly, grains that were considered sufficiently discordant or high-error by the original authors were omitted from our analyses. For studies that did not define an age cut-off at which the ${ }^{206} \mathrm{~Pb} /{ }^{238} \mathrm{U} v{ }^{207} \mathrm{~Pb} /{ }^{206} \mathrm{~Pb}$ age was chosen as the "best age", we systematically used an apparent age of $1000 \mathrm{Ma}$ as a threshold, using ${ }^{206} \mathrm{~Pb} /{ }^{238} \mathrm{U}$ ages for analyses $<1000 \mathrm{Ma}$ and ${ }^{207} \mathrm{~Pb} /{ }^{206} \mathrm{~Pb}$ ages for analyses $>1000 \mathrm{Ma}$. Age distributions were visualized using detritalPy (Sharman et al., 2018a). We assigned descriptors to each sample to indicate their tectonic setting and chronostratigraphic position (Supplemental Information, Table S2). Samples were defined as representing either the forearc or foreland basin system and were binned into subgroups representing specific parts of those basins based on sample location. In the forearc region, we subdivided samples into groups representing the Great Valley, Hornbrook, Ochoco, Methow, and Nanaimo forearc basins, as well as a group we term "borderland basins" (Fig. 1). The foreland samples were arbitrarily subdivided by latitude to represent southern $\left(28-34^{\circ} \mathrm{N}\right)$, central $\left(34-43^{\circ} \mathrm{N}\right)$, and northern $\left(43-48^{\circ} \mathrm{N}\right)$ parts of the foreland region (Fig. 1).

To compare temporal trends in data, samples were grouped according to their depositional epoch (e.g., Late Cretaceous or Paleocene). Cretaceous samples were further subdivided according to depositional age (e.g., Maastrichtian). Depositional ages of samples were defined following age determinations of the original authors, with two notable exceptions: 1) If more recent studies provided new age constraints on a given stratigraphic interval, we updated the ages of samples reported in older studies. 2) If a sample contained a cluster of young grains (herein $n$ $\geq 2$ ) that did not permit the stratigraphic age reported by the original authors, we updated the age of the sample to reflect its maximum depositional age (MDA) as suggested by the young grains (after Dickinson and Gehrels, 2009b; Copeland, 2020). All modifications to depositional age assignments are noted in the Supplemental Information (Table S2; Schwartz, 2021). For samples from units that may have been deposited over a range of potential geologic ages (e.g., AptianCenomanian), we assigned the oldest possible depositional age in the reported range (e.g., Aptian) unless the presence of young detrital zircon grains suggested a younger age.

\section{Results \& interpretations}

\subsection{Igneous zircon $U-P b$ age distributions}

We characterize the U-Pb age distribution of the North American Cordilleran arc using a compilation of $1307 \mathrm{U}-\mathrm{Pb}$ zircon ages ranging from 251 to $56 \mathrm{Ma}$ (Supplemental Information, Table S1; Schwartz, 2021). A composite distribution of ages from all arc segments displays a prominent Early to Late Cretaceous composite peak characterized by multiple sub-peaks, as well as subsidiary Triassic, Jurassic, and Paleocene peaks (Fig. 3f).

The Peninsular Ranges, Sierra Nevada, Idaho-Boulder, and Coast Mountains batholiths are unequally represented in the igneous zircon dataset, with numbers of constituent ages ranging from 130 (IdahoBoulder batholith) to 711 (Sierra Nevada batholith). Nonetheless, the age compilations highlight variations in zircon crystallization ages along the length of the Cordillera. The Peninsular Ranges batholith $(N=182)$ is characterized by ages ranging from $\sim 70$ to $170 \mathrm{Ma}$ with prominent Early Cretaceous (108 Ma) and Late Cretaceous (94 Ma) peaks (Fig. 3e). The Sierra Nevada batholith $(N=711)$, herein including plutons of the Klamath Mountains and ranges of northwest Nevada, is characterized by ages ranging from $\sim 70$ to $250 \mathrm{Ma}$, showing Late Jurassic (164 and 149 $\mathrm{Ma})$, Early Cretaceous (114 Ma), and Late Cretaceous (101 and $91 \mathrm{Ma}$ ) peaks (Fig. 3d). The Idaho-Boulder batholith complex $(N=130)$ is characterized by younger ages ranging from $\sim 56$ to $125 \mathrm{Ma}$, dominated by Late Cretaceous ( 91 and $76 \mathrm{Ma}$ ) and Paleocene (66 Ma) peaks (Fig. 3c). Ages from along the entirety of the Coast Mountains batholith $(N=284)$ range from $\sim 56$ to $240 \mathrm{Ma}$, revealing a complex age distribution characterized by many peaks (Fig. 3b). However, a suite of 40 ages from the southern Coast Mountains batholith (compiled from Friedman and Armstrong, 1995), most proximal to the study region, have a limited range from $\sim 80$ to $145 \mathrm{Ma}$ with Early Cretaceous (110 and $102 \mathrm{Ma}$ ) and Late Cretaceous (94 Ma) peaks that are similar to those in the Peninsular Ranges (Fig. 3e) and Sierra Nevada batholiths (Fig. 3d). The primary modes within the age distributions are generally consistent with previous work that discusses the flux of magmatism in the Cordillera, with peaks and valleys of the age distributions corresponding reasonably well with the timing of most magmatic HFEs (Fig. 3b-e; after Ducea, 2001; DeCelles et al., 2009; Gehrels et al., 2009; Paterson et al., 2011; Girardi et al., 2012; Gaschnig et al., 2016; Jiang and Lee, 2017). For HFEs that do not coincide with prominent zircon age peaks, such as those interpreted at $\sim 150 \mathrm{Ma}$ in the Coast Mountains batholith and at $\sim 100 \mathrm{Ma}$ in the Idaho batholith, we attribute such discrepancies to the determination of HFEs via calculation of areal addition rates (e.g., Gehrels et al., 2009; Gaschnig et al., 2016), which are not simply based on the proportions of igneous zircon ages that are available for a magmatic body.

\subsection{Detrital zircon data distributions}

\subsubsection{Spatial distribution of samples}

Our compilation of detrital zircon U-Pb age data includes 830 samples from the forearc and foreland basins of the North American Cordillera, comprising 101,898 individual grain analyses. Individual sample sizes range from 9 to 387 grains and show a weakly bimodal distribution (Fig. 4). The primary mode comprises the middle $50 \%$ of sample sizes for both the forearc and foreland sample suites, with 


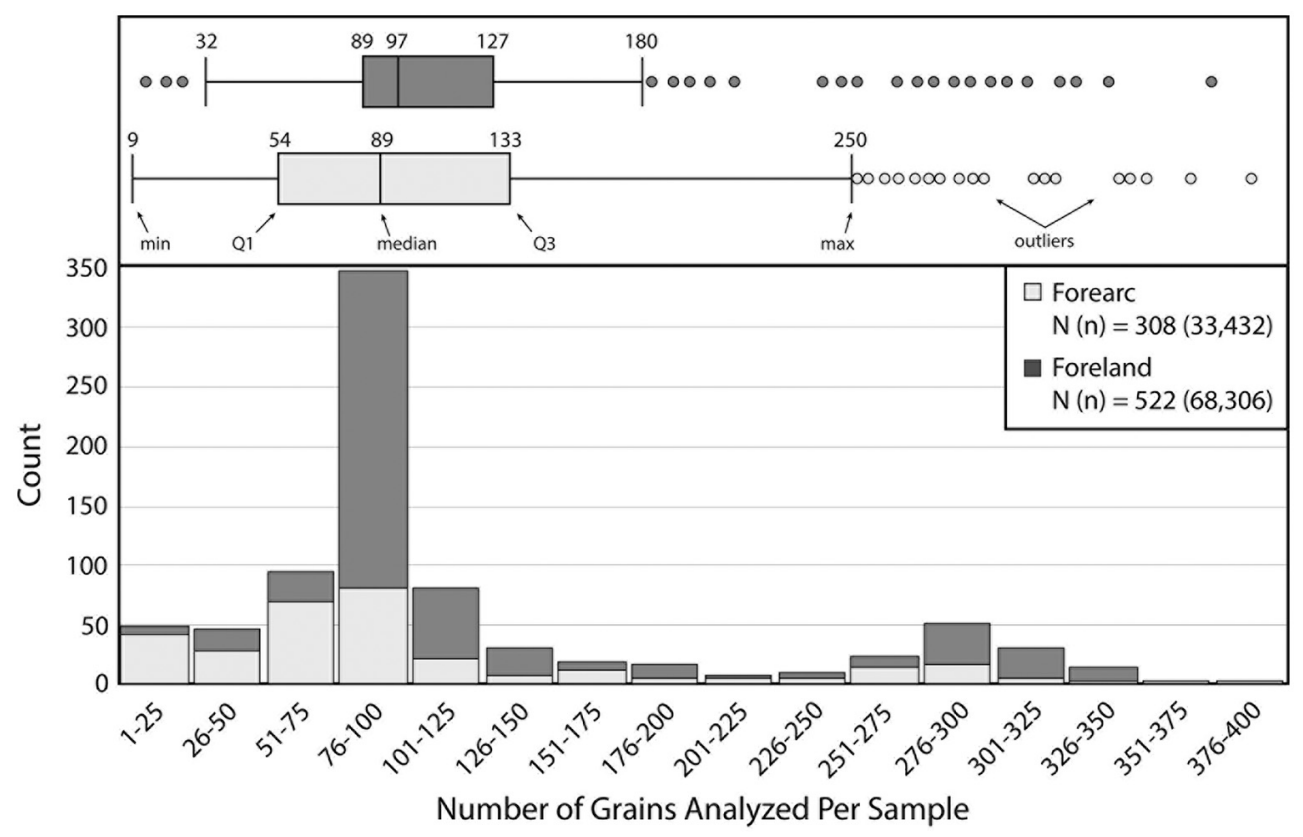

Fig. 4. Distribution of constituent analyses in detrital zircon samples compiled from the Cordilleran forearc and foreland regions.

median sample sizes of 89 grains in the forearc and 97 grains in the foreland. A subsidiary mode accounts for less than $20 \%$ of all samples in the dataset, made up of samples sizes of $>225$ grains.

The Cordilleran forearc region is represented by 308 samples in the dataset (37\% of all samples and $33 \%$ of all grain ages). These are variably distributed across the Great Valley $(N=64)$, Hornbrook $(N=26)$, Ochoco $(N=24)$, Methow $(N=48)$, Nanaimo $(N=68)$, and "borderland" $(N=78)$ sectors of the forearc (Fig. 1). The Cordilleran foreland region is represented by the remaining 522 detrital zircon samples in the compilation ( $63 \%$ of all samples and $67 \%$ of all grain ages). The foreland basin samples are variably distributed across the foreland region, representing depozones ranging from hinterland and wedge-top to distal forebulge and backbulge environments. For comparative purposes we subdivide samples by latitude to represent the southern, central, and northern foreland between 28 and $34^{\circ} \mathrm{N}(N=56), 34-43^{\circ} \mathrm{N}(N=359)$, and $43-48^{\circ} \mathrm{N}(N=107)$ (Fig. 1).

\subsubsection{Temporal distribution of samples}

The 830 detrital zircon samples in our compilation were collected from Jurassic to Paleocene strata. Samples are binned into eight stratigraphic age groups that represent an average duration of $\sim 18$ Myr: Early Jurassic $\left(\mathrm{J}_{1}, 201.3-171.4\right.$ Ma, foreland only), Middle Jurassic $\left(\mathrm{J}_{2}\right.$, 174.1-163.5 Ma, foreland only), Late Jurassic ( $\left.\mathrm{J}_{3}, 163.5-145.0 \mathrm{Myr}\right)$; Early Cretaceous, Berriasian-Barremian ( $\left.\mathrm{K}_{1}, 145.0-125.0 \mathrm{Ma}\right)$; Early Cretaceous, Aptian-Albian ( $\left.\mathrm{K}_{2}, 125.0-100.5 \mathrm{Ma}\right)$; Late Cretaceous, Cenomanian-Santonian $\left(\mathrm{K}_{3}, 100.5-83.6 \mathrm{Ma}\right)$; Late Cretaceous, Campanian-Maastrichtian $\left(\mathrm{K}_{4}, \quad 83.6-66.0 \mathrm{Ma}\right)$; and Paleocene (66.0-56.0 Ma). Note that Early and Middle Jurassic samples from the foreland region may predate the existence of a definitive magmatic arc (after Dickinson et al., 1996; DeCelles, 2004); yet, we consider these samples in our analysis because samples of this age correspond to early phases of arc evolution.

Late Cretaceous samples account for $\sim 60 \%$ of all samples in the compilation (Fig. 5). Early Cretaceous, Paleocene, and Jurassic samples respectively make up $\sim 19 \%, \sim 13 \%$, and $\sim 8 \%$ of the dataset. Of the forearc depocenters, the Great Valley forearc is best represented by detrital samples, with samples from Upper Jurassic $\left(J_{3}\right)$ through Paleocene strata. Similarly, the central foreland region is best represented by detrital samples from Lower Jurassic $\left(\mathrm{J}_{1}\right)$ through Paleocene strata.

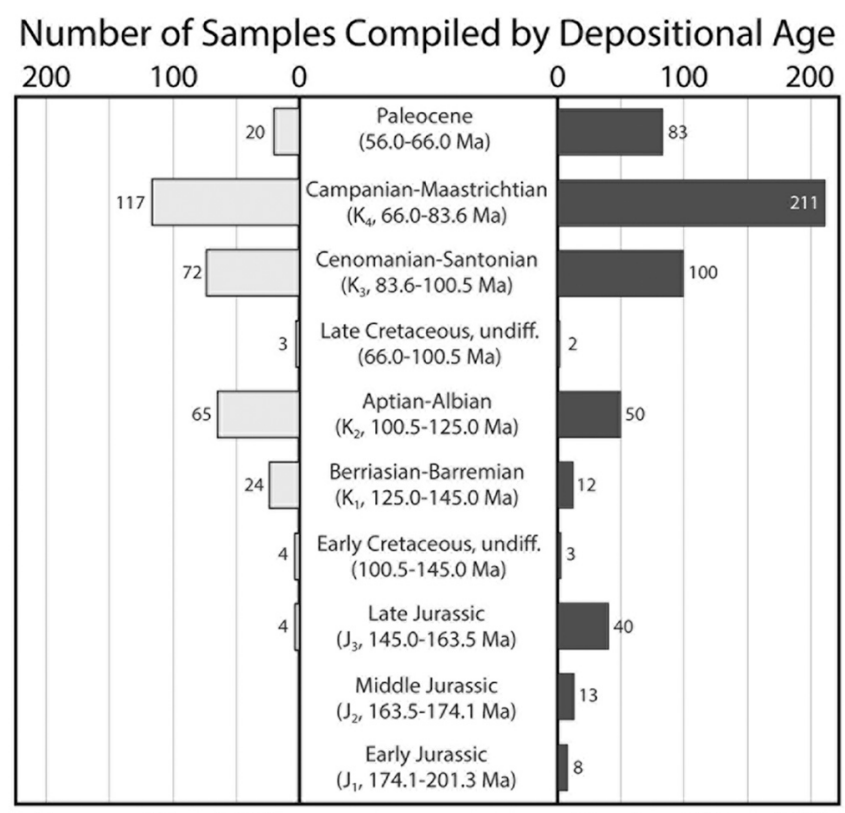

Forearc $\left(\mathrm{N}_{\mathrm{tot}}=308\right)$

Foreland $\left(\mathrm{N}_{\mathrm{tot}}=522\right)$

Fig. 5. Temporal distribution of detrital zircon samples from the Cordilleran forearc and foreland regions.

\subsubsection{Age components of detrital zircon samples}

4.2.3.1. Pre-arc grains $(>251 \mathrm{Ma})$. Both the forearc and foreland regions contain substantial numbers of detrital zircon grains $>251$ Ma that respectively compose $16 \%$ and $80 \%$ of the composite forearc and foreland distributions (Fig. 6a). Within the forearc distribution, small peaks are apparent at $\sim 350,1000,1400$, and $1700 \mathrm{Ma}$ (Fig. 6a). The foreland distribution shows a more diverse set of peaks at $\sim 420,600,1000,1400$, 1700, 2000, and $2700 \mathrm{Ma}$ (Fig. 6a).

We interpret the bulk of pre-arc grain ages in the composite forearc and foreland distributions as derived either directly from North American crustal provinces corresponding to those ages and/or recycled from 


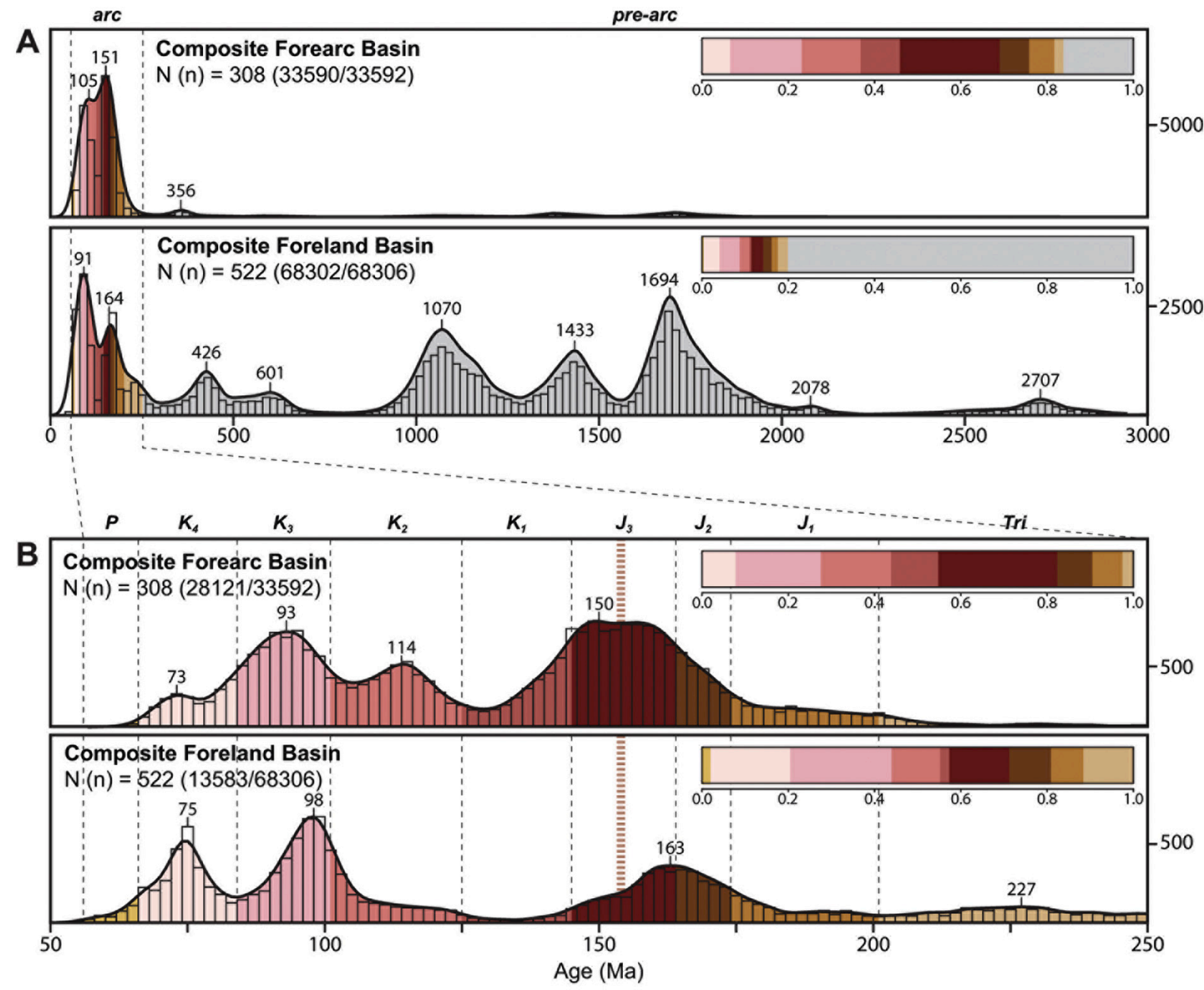

Fig. 6. Histograms and KDEs showing composite detrital zircon distributions for forearc and foreland basins of the North American Cordillera: (A) Composite age distributions between 0 and $3500 \mathrm{Ma}$ (histogram bin width = $20 \mathrm{Ma}$, KDE bandwidth =20); (B) Composite age distributions trimmed to 50-250 Ma highlighting arcderived ages (251-56 Ma; histogram bin width $=2 \mathrm{Ma}$; KDE bandwidth $=2$ ). In each panel, the inset stacked histograms show the relative proportions of arc and prearc ages composing their associated age distributions. Red, dashed line at $154 \mathrm{Ma}$ indicates the approximate timing of arc integration as suggested by Dickinson et al. (1996), DeCelles (2004), and Surpless et al. (2006). (For interpretation of the references to colour in this figure legend, the reader is referred to the web version of this article.)

metamorphic and sedimentary units that had been exposed across different parts of the orogen. Peaks at $\sim 420,600,1000,1400,1700$, and 2700 Ma relate to well-accepted ages of the Appalachian ( $\sim 500-250$ Ma), Amarillo-Wichita ( $\sim 575-500 \quad \mathrm{Ma})$ or Yucatan-Compeche ( $\sim 975-575 \mathrm{Ma})$, Grenville ( 1200 to $975 \mathrm{Ma})$, Mesoproterozoic magmatic ( 1600-1200 Ma), Yavapai-Mazatzal ( 1800-1600 Ma), and Archean ( $>2500 \mathrm{Ma}$ ) crustal provinces of North America (after Whitmeyer and Karlstrom, 2007; Gehrels et al., 2011). We note, however, that North American crustal provinces were largely covered by Paleozoic and early Mesozoic sediments at the onset of Cordilleran orogenesis, indicating that most pre-arc grains in the forearc and foreland distributions were more likely recycled from metamorphic and/or sedimentary successions exposed in the orogen (Schwartz et al., 2019b). In the foreland region, sedimentary units composing the adjacent foldthrust belt are expected to be a primary source of sediment (e.g., Dickinson and Suczek, 1979; Dickinson et al., 1983). Recycling of detrital zircon grains from the fold-thrust belt into the foreland is strongly supported by close similarities between pre-arc age distributions in the foreland composite and compilations of detrital zircon data for Mesoproterozoic through Mesozoic strata currently exposed in the fold-thrust belt and foreland region (e.g., Dickinson et al., 2009; Gehrels et al., 2011; Laskowski et al., 2013; Schwartz et al., 2019b). Recycled pre-arc grains may also have been derived from Neoproterozoic to Triassic terranes that were exposed in the Sevier hinterland during the Late Jurassic-Cretaceous (e.g., Colgan and Henry, 2009; Van Buer et al., 2009; Long, 2012), as well as from Devonian to Jurassic accreted terranes that were exposed along the continental margin (e.g., Irwin, 2003).

4.2.3.2. Arc-derived zircon (251-56 Ma). Based on well-accepted conceptual models of convergent margins, Cordilleran arcs, and their adjacent basins, sediment derived from volcanic and/or plutonic sources in the arc should be transported to and sequestered in associated forearc and foreland basins (Fig. 2; e.g., Dickinson and Suczek, 1979; Dickinson et al., 1983). In this study, we single out arc-derived zircon grains with ages between 251 and $56 \mathrm{Ma}$ as "tracers" to discuss how widely arcderived sediments are dispersed within basins adjacent to the arc. Of 308 samples that represent the forearc basin system, 100\% contain arcderived grains between 251 and $56 \mathrm{Ma}$. In the foreland region, 476 of 522 samples (91\%) contain arc-derived grains. The likelihood of encountering arc-derived grains is high in both basins and is nearly guaranteed in the forearc region. Thus, we interpret that the Cordilleran magmatic arc was a source of zircon to both basin systems.

Detrital samples show strong spatial variability in their proportions 

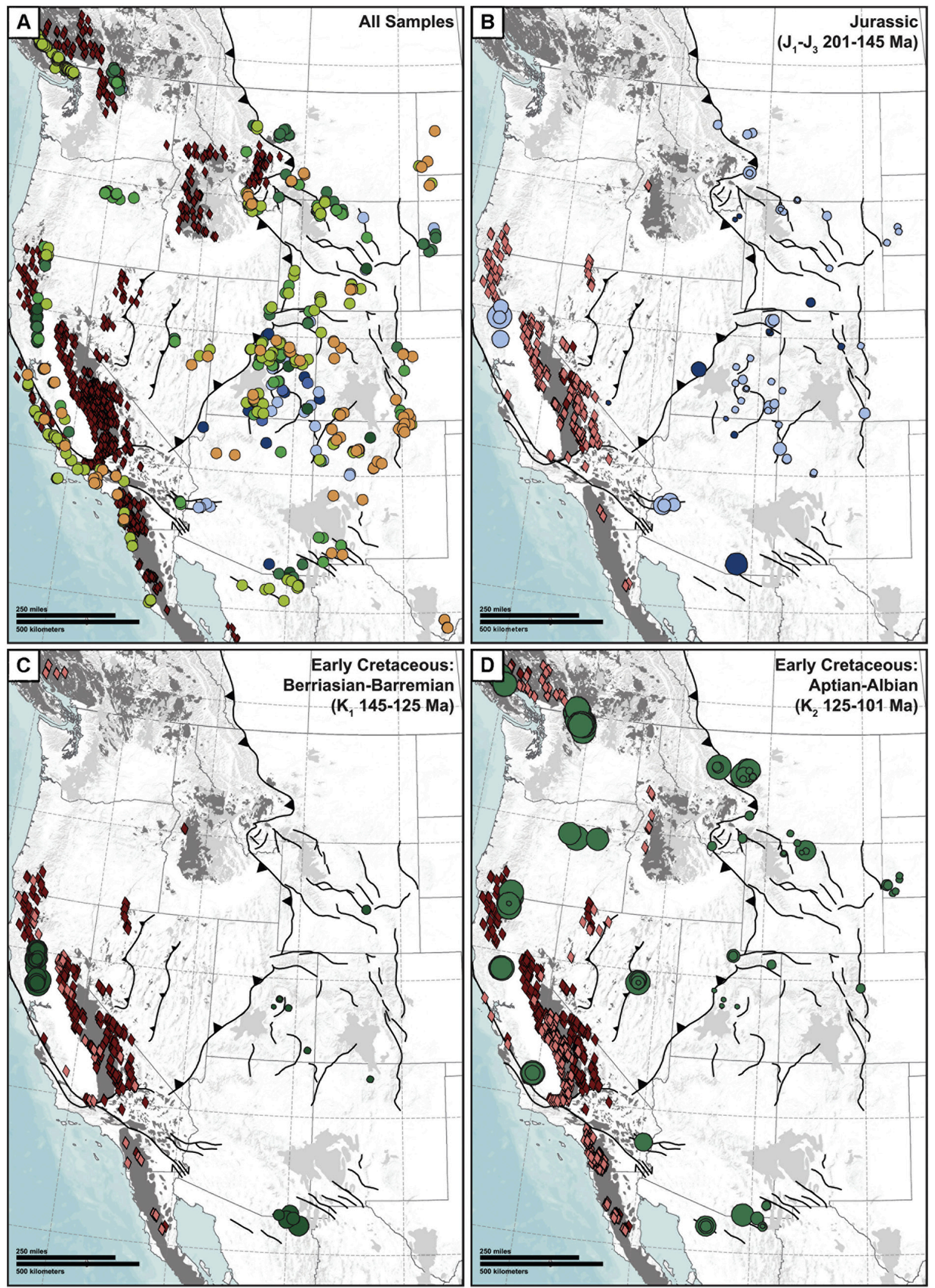

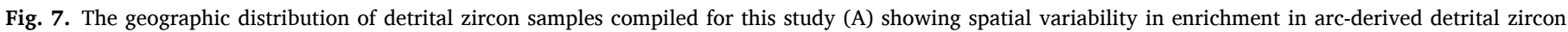

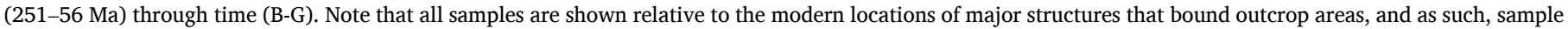
locations may not truly reflect their original depositional location. 

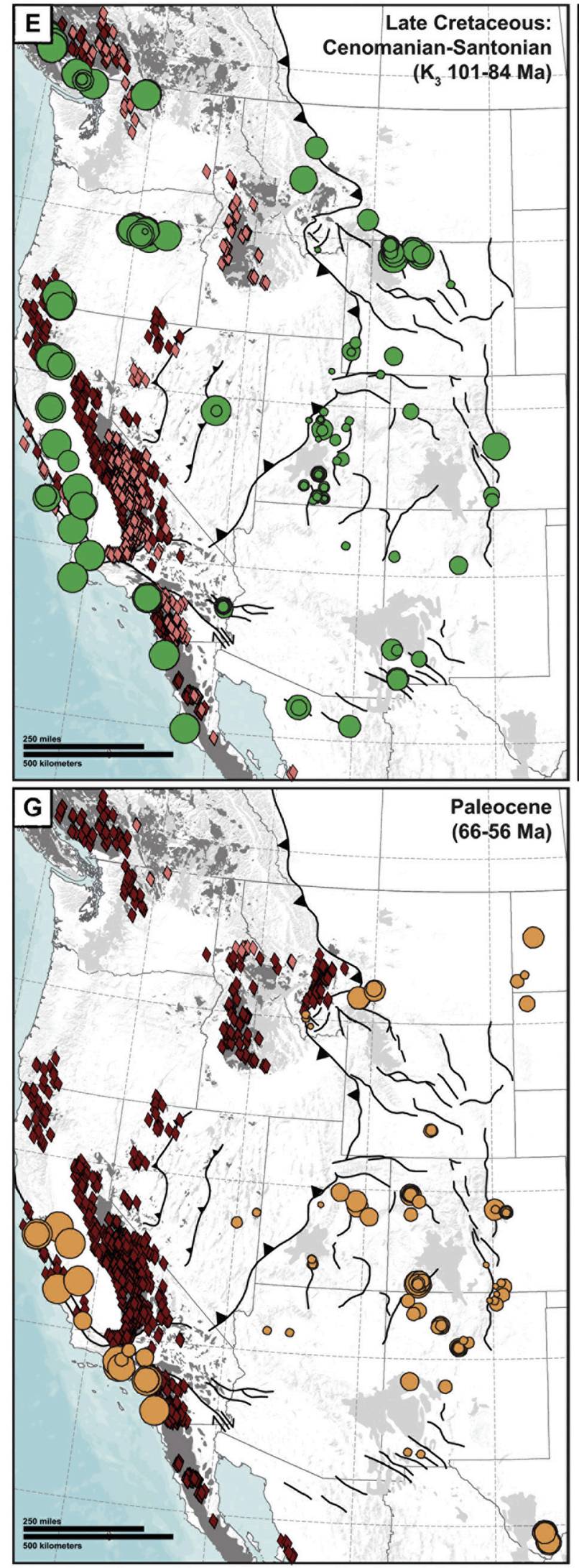

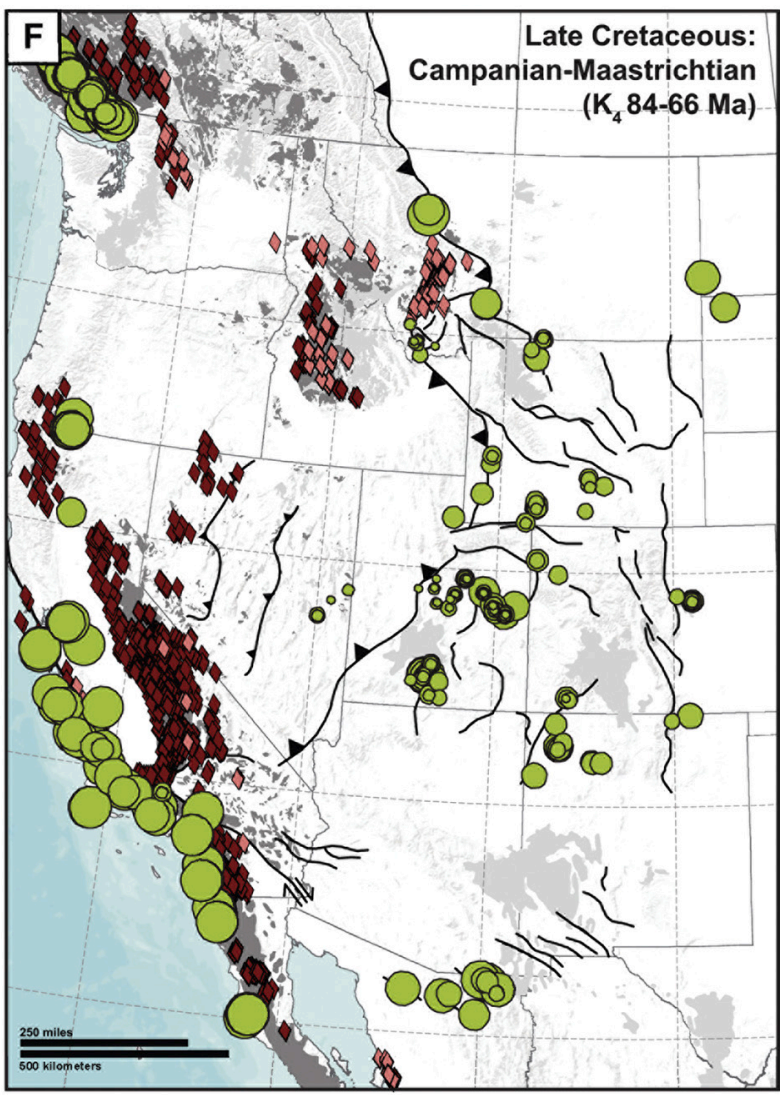

Igneous zircon $\mathrm{U}-\mathrm{Pb}$ age

$\checkmark$ depositional age-equivalent crystallization age

$\checkmark$ older crystallization age

Age and location of detrital zircon sample

Paleocene (66-56 Ma)

$\mathrm{K}_{4}$ Campanian-Maastrichtian (84-66 Ma)

$\mathrm{K}_{3}$ Cenomanian-Santonian (101-84 Ma)

$\mathrm{K}_{2}$ Aptian-Albian (125-101 Ma)

$\mathrm{K}_{1}$ Berriasian-Barremian (145-125)

$\mathrm{J}_{3}$ Late Jurassic (164-145 Ma)

$\mathrm{J}_{2}$ Middle Jurassic (174-164 Ma)

$\mathrm{J}_{1}$ Early Jurassic (201-174 Ma)

Proportion of arc-derived zircon in a detrital zircon sample

- $0-1 \%$

- $2-10 \%$

- $11-20 \%$

$21-30 \%$

$31-40 \%$

$41-50 \%$

$51-60 \%$

$61-70 \%$

$71-80 \%$

$81-90 \%$

$91-100 \%$

Fig. 7. (continued). 
of arc-derived grains (Fig. 7). Within the forearc basins, most samples (91\%) are composed of at least $50 \%$ arc-derived zircon, with very few samples (9\%) that contain a majority of pre-arc zircon. In contrast, proportions of arc-derived zircon are highly variable across the foreland region. For example, Aptian-Albian samples (Fig. 7d) are enriched in arc-derived zircon in the southern and northern portions of the foreland but contain a paucity of arc-derived zircon in the central foreland. Cenomanian-Santonian samples (Fig. 7e) from the northern and southern foreland regions remain relatively enriched in arc-derived zircon, as are samples along the eastern periphery of the basin; equivalent samples in the central foreland have low proportions of arc-derived grains. Campanian-Maastrichtian and Paleocene samples (Fig. 7f-g) are highly variable in their enrichment, with enriched and unenriched samples closely associated in space.

4.2.3.3. Coeval arc-derived zircon. As a subset of arc-derived zircon, we also single out "coeval arc-derived zircon" as grains with ages that overlap the depositional age of their host strata. There is substantial variability in the proportions of coeval arc-derived zircon across both the forearc and foreland regions. Only 224 of 308 samples (73\%) in the forearc and 319 of 522 samples (61\%) in the foreland contain depositional age-equivalent grains. These trends suggest that although the likelihood of encountering arc-derived grains is nearly $100 \%$ in the forearc region, the likelihood of encountering depositional ageequivalent grains is reduced to about $75 \%$. Foreland basin samples are less likely to contain arc-derived grains of any age, and their likelihood to contain depositional age-equivalent grains is only about $60 \%$.

\subsubsection{Composite detrital zircon signatures of the forearc and foreland regions}

Both the forearc and foreland regions contain grains ranging from 251 to $56 \mathrm{Ma}$, but in vastly different proportions (Figs. 6, 7). The forearc detrital zircon record is dominated by arc-derived grains, with ages 251-56 Ma composing $84 \%$ of the dataset (Fig. 6a). Only $16 \%$ of the forearc detrital signature is composed of grains with ages $>251 \mathrm{Ma}$, scattered between 250 and $2500 \mathrm{Ma}$. Within the spectrum of arc-derived grains, Jurassic grains dominate (43\% between 201 and $145 \mathrm{Ma}$ ), followed by equal proportions of Early (27\% between 145 and $100 \mathrm{Ma}$ ) and Late Cretaceous (27\% between 100 and $66 \mathrm{Ma}$ ) grains, with minor Triassic ( $3 \%$ between 251 and $201 \mathrm{Ma}$ ) and Paleocene ( $<1 \%$ between 66 and $56 \mathrm{Ma}$ ) grains. These proportions are highlighted in Fig. $6 \mathrm{~b}$ by peaks at $\sim 160-150,114,93$, and 73 Ma.

In contrast, the foreland detrital zircon signature is dominated by pre-arc zircon with $80 \%$ of ages $>251 \mathrm{Ma}$. The pre-arc spectrum includes prominent peaks at $\sim 426,601,1070,1433,1694,2078$, and $2707 \mathrm{Ma}$ (Fig. 6a). Only $20 \%$ of detrital zircons in the foreland region are arcderived. Nearly half of those are Late Cretaceous (42\% between 100 and $66 \mathrm{Ma}$ ), followed by Jurassic (31\% between 201 and $145 \mathrm{Ma}$ ), Early Cretaceous (13\% between 145 and $100 \mathrm{Ma}$ ), Triassic (12\% between 251 and $201 \mathrm{Ma}$ ) and Paleocene ( $2 \%$ between 66 and $56 \mathrm{Ma}$ ) grains. These proportions are highlighted in Fig. $6 \mathrm{~b}$ by peaks at 163, 98, and $75 \mathrm{Ma}$, with a broad, low peak at 227 Ma.

Although both basin complexes contain strong arc signals between 251 and $56 \mathrm{Ma}$, they are differentiable based on the relative presence or absence of some age groups. The foreland hosts a more pronounced Triassic record (12\% of arc ages) with a broad peak centered at $227 \mathrm{Ma}$, whereas Triassic grains are rare in the forearc (3\% of arc ages). The forearc, however, contains more prominent Jurassic (43\% of arc ages compared to $31 \%$ in the foreland) and Early Cretaceous (27\% of arc ages compared to $13 \%$ in the foreland) records. Both basins preserve obvious Late Cretaceous records, but they also differ: the foreland basin samples show a distinct bimodal grouping of Late Cretaceous grains with peaks at 98 and $75 \mathrm{Ma}$ (42\% of arc ages), whereas the forearc basin samples show weaker bimodality with a robust peak at $93 \mathrm{Ma}$ and a smaller peak at 73 Ma (27\% of arc ages). Finally, the foreland preserves a weak Paleocene record ( $2 \%$ of arc ages), whereas Paleocene ages are very rare in the forearc.

\section{Discussion}

\subsection{Comparison of in situ and detrital zircon records of the arc}

\subsubsection{Detrital record of magmatic activity}

Our compilation of 1307 in situ zircon U-Pb ages from North American Cordilleran arc rocks (Fig. $3 \mathrm{f}$ ) documents a prolonged, multistage emplacement of batholiths along the western margin of the continent during Mesozoic and early Cenozoic time. Abundant MiddleLate Jurassic, Early Cretaceous, and Late Cretaceous crystallization ages form distinct peaks (consistent with Barth et al., 2013; Fig. 3f), as expected with episodic arc magmatism and as suggested by prior authors (e.g., Ducea, 2001; DeCelles et al., 2009). The compiled data also demonstrate that arc magmatism was spatially variable, with the bulk of magmatism between $\sim 174$ and 90 Ma focused in the Peninsular Ranges, Sierra Nevada, and Coast Mountains batholiths, and magmatism between $\sim 90$ and 56 Ma focused primarily in the Idaho-Boulder batholith (Fig. 3b-e).

Because the igneous zircon ages summarized in Fig. 3 are inherently biased by location- and age-based disparities in sample density, we suggest that our compilation of detrital zircon ages from Cordilleran forearc and foreland basins provides a more robust record of Cordilleran magmatic activity. Together, Jurassic through Paleocene detrital zircon samples from forearc and foreland depocenters provide an integrated record of zircon $\mathrm{U}-\mathrm{Pb}$ ages derived from the arc that amount to more than 30-times the zircon U-Pb ages available from in situ arc rocks ( $n=$ 41,594 detrital zircon ages between 251 and $56 \mathrm{Ma}$ ). Although sample bias is also present in the detrital record because detrital zircon samples are not evenly distributed spatially across basins or through stratigraphy within basins (Figs. 4, 5), the compilation of detrital ages inherently subdues age- and location-bias by integrating detrital data into composite age distributions (e.g., Barth et al., 2013). For this reason, we propose that the shapes of the composite forearc and foreland distributions (Fig. 6), and better yet, a composite of both (Fig. 8), best approximate bulk flux in arc activity through time.

In general, the composite forearc and foreland basin records parallel the in situ arc record and show high proportions of detrital zircon ages forming prominent Middle Jurassic to Early Cretaceous ( 174-140 Ma), Early Cretaceous $(\sim 120-108 \mathrm{Ma})$, and Late Cretaceous ( 101-84 Ma and $\sim 80-70 \mathrm{Ma}$ ) peaks (Fig. 8). The detrital record more clearly subdivides age distributions into discrete peaks separated by valleys, compared to the igneous record that is characterized by two broad age peaks with multiple internal modes (Fig. 8). The peaks in the detrital zircon distributions shown in Fig. 8 generally correspond to HFEs that have been interpreted for the batholiths (e.g., Fig. 3b-e; Ducea, 2001; DeCelles et al., 2009; Gehrels et al., 2009; Paterson et al., 2011; Girardi et al., 2012; Gaschnig et al., 2016; Jiang and Lee, 2017): The broad peak at $~ 160-150$ Ma overlaps with HFEs that have been interpreted for the Sierra Nevada and Coast Mountains batholiths; the peak at $\sim 96 \mathrm{Ma}$ overlaps with HFEs that have been interpreted for all batholiths, including a speculated early phase of the Idaho batholith that is not wellrepresented by exposed magmatic rocks (e.g., Gaschnig et al., 2016); and the youngest peak at $\sim 74$ Ma overlaps with the main flux of magmatism in the Idaho-Boulder batholith. This correlation suggests that each prominent peak in the composite detrital zircon distribution reflects the occurrence of a HFE somewhere in the arc.

Accordingly, we posit that the prominent peak at $\sim 114$ Ma (Fig. 8) indicates a previously unrecognized Aptian-Albian HFE. The $\sim 114 \mathrm{Ma}$ peak corresponds to Early Cretaceous igneous zircon $\mathrm{U}-\mathrm{Pb}$ ages reported for the Peninsular Ranges, Sierra Nevada, and Coast Mountains batholiths, but it does not correspond to a HFE interpreted for any of those batholith segments (Fig. 3b, d-e). Detrital zircon ages that compose the $\sim 114$ Ma peak are concentrated in the forearc region and are less 


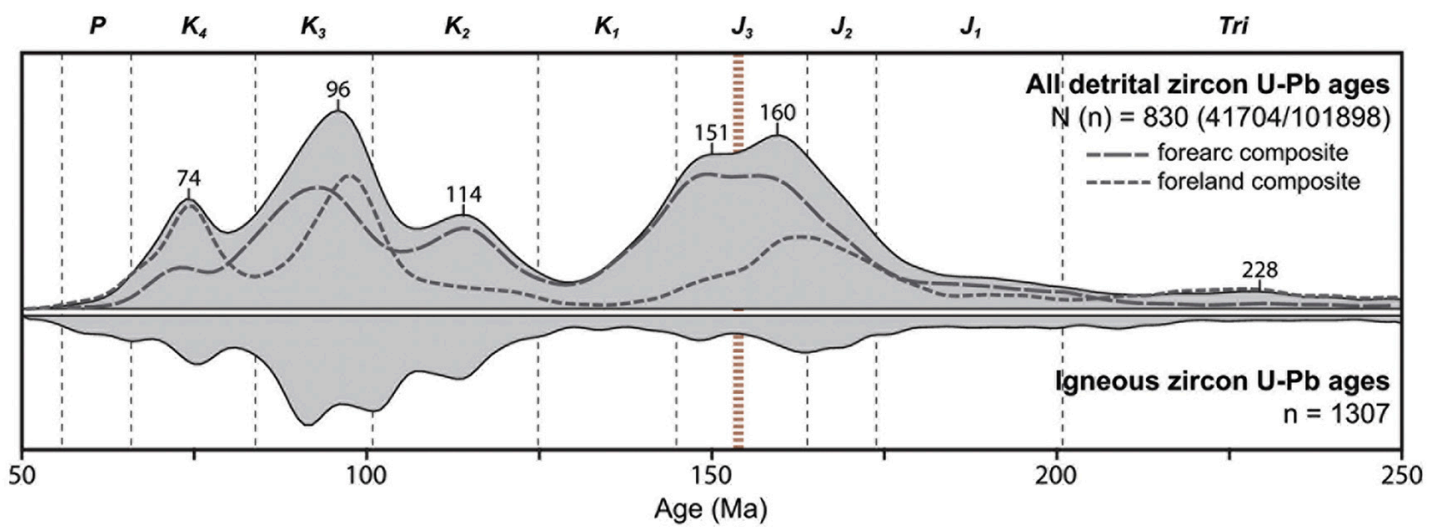

Fig. 8. Comparison of KDEs representing the igneous and detrital zircon U-Pb age distributions of magmatic rocks in the Cordilleran arc (lower) and JurassicPaleocene sandstones in the forearc and foreland basins (upper; KDE bandwidth $=2$ for all curves). Red, dashed line at 154 Ma indicates the approximate timing of arc integration as suggested by Dickinson et al. (1996), DeCelles (2004), and Surpless et al. (2006). (For interpretation of the references to colour in this figure legend, the reader is referred to the web version of this article.)

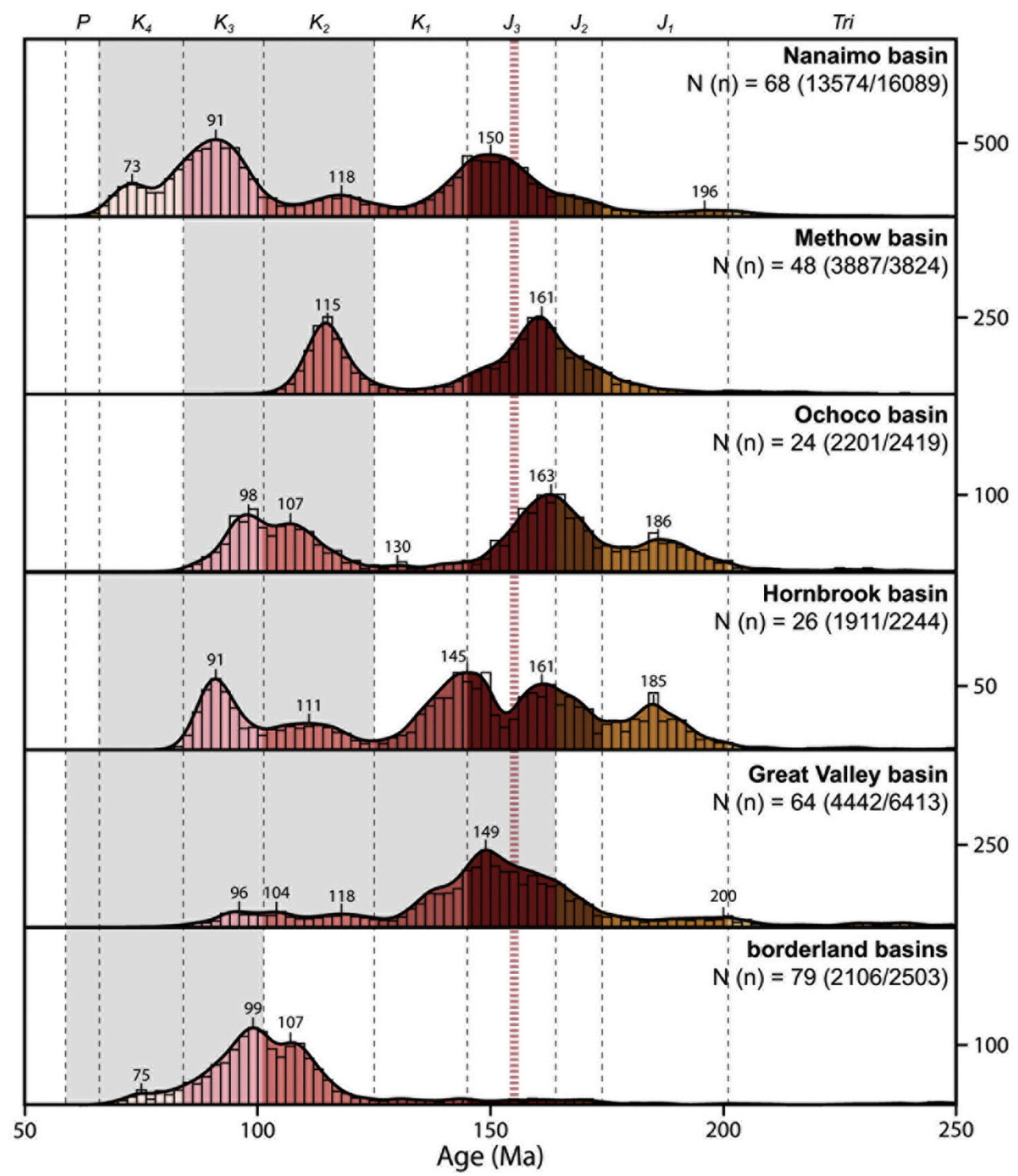

Fig. 9. Histograms and KDEs showing the composite detrital zircon distributions for the various forearc basins considered in this study, highlighting proportions of arcderived zircon between 50 and $250 \mathrm{Ma}$ (histogram bin width $=2 \mathrm{Ma}$; KDE bandwidth $=2$ ). Gray shading indicates the agerange of strata from which detrital zircon samples were collected in each basin. Red, dashed line at $154 \mathrm{Ma}$ indicates the approximate timing of arc integration as suggested by Dickinson et al. (1996), DeCelles (2004), and Surpless et al. (2006). (For interpretation of the references to colour in this figure legend, the reader is referred to the web version of this article.) 
abundant in the foreland (Figs. 6b, 8). Within the forearc, Aptian-Albian ages are present in all basins but form unique peaks in the Methow, Nanaimo, and Hornbrook basins, with peaks at $\sim 115,118$, and $111 \mathrm{Ma}$, respectively (Fig. 9). Following the rationale that prominent peaks in the composite detrital zircon distributions reflect HFEs and based on interpretations of sediment provenance for the Methow, Nanaimo, and Hornbrook basins (DeGraaff-Surpless et al., 2003; Surpless et al., 2014; Coutts et al., 2020), we suggest that the presence of the $\sim 114$ Ma peak in Fig. 8 identifies an Aptian-Albian HFE in the Cordilleran arc.

\subsubsection{Detrital record of arc inception}

Although we simplify the timing of integration of the Cordilleran arc as occurring ca. 155-153 Ma (after Dickinson et al., 1996; DeCelles, 2004; Surpless et al., 2006), sustained, eastward subduction of the Farallon plate beneath North America was preceded by episodes of Permian to Middle Jurassic magmatism, island arc accretion, and ophiolite obduction that have been explained by multiple, controversial models. Models for arc inception variably invoke Late Jurassic (ca. 162-155 Ma) arc-arc collision related to the dual presence of east- and west-verging subduction zones beneath offshore island arcs (e.g., Schweickert and Cowan, 1975; Ingersoll and Schweickert, 1986; Ingersoll, 2000, 2008, 2019; Schweickert, 2015); Early-Middle Jurassic (ca. 180-165 Ma) subduction of the Farallon plate with Early Cretaceous (ca. $123 \mathrm{Ma}$ ) terrane accretion (Wakabayashi, 1992, 2015; Saleeby, 1996; Shervais, 2001; Dumitru et al., 2010; Mulcahy et al., 2018); and much earlier, Permian-Triassic (ca. 256-248 Ma) intrusion of Sierra Nevada plutons along a remnant transform margin (Saleeby and Dunne, 2015; Levy et al., 2020) with extension occurring in the backarc region through Middle Jurassic time (Busby-Spera et al., 1990).

Permian to Triassic inception of arc magmatism is supported by the presence of Permian and Triassic plutons scattered throughout the Sierra Nevada batholith, the adjacent Mojave Desert, and Sonora, Mexico (Barth and Wooden, 2006; Cecil et al., 2019). Such plutons are poorly represented in our compilation of in situ zircon U-Pb ages; Triassic ages constitute only $5 \%$ of ages compiled for the Sierra Nevada batholith (Fig. 3f), and we purposefully did not include Permian ages in our compilation to simplify the time period over which data were analyzed. In contrast, Triassic to middle-Late Jurassic ( $251-155 \mathrm{Ma})$ ages are relatively abundant in our compilation of detrital zircon ages, accounting for $\sim 35 \%$ of arc-derived grains in the foreland region and $\sim$ $25 \%$ of arc-derived grains in the forearc region (Fig. 6b). Late Permian ages ( $\sim 300-250 \mathrm{Ma})$ are rare, accounting for only $\sim 1 \%$ of all detrital zircon ages compiled in this study. We note that Permian-Triassic detrital zircons are also variably abundant in Triassic strata of the Colorado Plateau (Riggs et al., 2013, 2016, 2020), which are not included in our compilation, likely rendering the compiled data underrepresentative of the full distribution of Permian-Triassic detrital zircon ages present in Cordilleran strata. Yet, the Triassic to middle-Late Jurassic ages ( $\sim 251-155 \mathrm{Ma})$ shown in Fig. $6 \mathrm{~b}$ provide a clear signal of magmatism prior to integration of the Cordilleran arc at approximately 155 Ma. The broad, continuous distribution of Triassic and Early Jurassic detrital zircon ages from foreland basin strata record a prolonged history of magmatism between $\sim 251$ and $174 \mathrm{Ma}$, after which Middle and Late Jurassic detrital zircon ages between $\sim 174$ and $155 \mathrm{Ma}$ are relatively abundant. Although Triassic to Middle Jurassic detrital zircon ages are less abundant in forearc basin strata, their distributions and relative abundances are similar to those in the foreland region. Notably, higher proportions of Middle and Late Jurassic detrital zircons beginning at $\sim 164 \mathrm{Ma}$ are generally consistent with the interpreted timing of a HFE in the Sierra Nevada batholith (e.g., Fig. 3d; Ducea, 2001; DeCelles et al., 2009). Based on this pattern, we suggest that the broad distribution of detrital zircon ages between $\sim 251$ and $174 \mathrm{Ma}$ shown in Fig. 6b records a prolonged history of continuous, but relatively low-volume, magmatism prior to integration of the Cordilleran arc in Late Jurassic time.

\subsubsection{Detrital record of a missing arc? The mid-Cretaceous Idaho batholith}

Magmatic rocks of the Idaho batholith record a phase of high-flux magmatism at $\sim 76 \mathrm{Ma}$, approximately $20 \mathrm{Myr}$ after high-flux magmatism in the Peninsular Ranges, Sierra Nevada, and Coast Mountains batholiths (Fig. 3c). Gaschnig et al. (2016) demonstrated the presence of abundant $\sim 98-87$ Ma xenocrysts in latest Cretaceous plutons, supporting a history of relatively continuous magmatism in the Idaho batholith from $\sim 110-43 \mathrm{Ma}$ even though the present age distribution of magmatism is strongly biased toward its youngest phases. Pre-85 Ma evidence of the batholith was largely eradicated by tectonic shortening along the western Idaho shear zone between $\sim 100$ and $92 \mathrm{Ma}$ (Giorgis et al., 2005, 2008) followed by progressive magmatic overprinting and erosion after $\sim 92 \mathrm{Ma}$ (Gaschnig et al., 2016). If a substantial volume of pre-85 Ma arc rocks was eroded from the Idaho batholith, a record of such erosion should be preserved in adjacent basins. Gaschnig et al. (2016) cited some detrital zircon evidence for this from the Cretaceous foreland (Stroup et al., 2008; Fuentes et al., 2011; Laskowski et al., 2013), but with the exception of Stroup et al. (2008), the cited studies did not specifically address the Idaho batholith as a source of pre-85 Ma detrital zircon.

Cretaceous detrital zircon samples compiled from northern forearc and foreland regions clearly record the initiation and erosion of a 110-85 Ma Idaho arc. Aptian-Albian $\left(\mathrm{K}_{2}\right)$ samples from the Ochoco forearc basin, currently located due west of the Idaho batholith (Fig. 1), contain relatively abundant $\mathrm{K}_{2}$ grains (peak age $\sim 108 \mathrm{Ma}$ ) mixed with Jurassic and pre-arc grains (Figs. 9, 10a). Cenomanian-Santonian $\left(\mathrm{K}_{3}\right)$ samples from the Ochoco basin contain abundant $\mathrm{K}_{2}$ grains and highlight an influx of abundant $K_{3}$ grains (peak age $\sim 97$ Ma; Figs. 9, 10a). Surpless and Gulliver (2018) interpreted the mid-Cretaceous Idaho arc as one of multiple arc sources to the Albian-Campanian Ochoco basin (with others including the Klamath Mountains, northern Sierra Nevada arc, and southern Coast Mountains arc), and as such, Ochoco basin samples provide insight into the ages of missing magmatic rocks associated with the Idaho arc.

Coeval deposits in the foreland provide an independent record of the Idaho arc that is likely uncomplicated by the presence of multiple arc sources. Aptian-Albian samples from the Montana-Wyoming foreland region closely mimic the detrital zircon distribution of coeval Ochoco basin samples, characterized by large proportions of Middle-Late Jurassic (peak age $\sim 160 \mathrm{Ma}$ ) and Aptian-Albian (peak age $\sim 111 \mathrm{Ma}$ ) grains (Fig. 10b). Following this, Cenomanian-Santonian samples from the foreland are characterized by abundant $\mathrm{K}_{2}$ and $\mathrm{K}_{3}$ grains (peak age $\sim 98 \mathrm{Ma}$ ) with only rare Jurassic grains (Fig. 10b). $K_{2}$ and $K_{3}$ grains continue to be present in relatively large proportions of some northern foreland samples throughout the Campanian-Maastrichtian $\left(\mathrm{K}_{4}\right)$ while $\mathrm{K}_{4}$ grains simultaneously become dominant (Fig. 10b). We suggest that the progressive introduction of large proportions of depositional ageequivalent grains to the northern foreland region in Aptian-Albian $\left(\mathrm{K}_{2}\right)$, Cenomanian-Santonian $\left(\mathrm{K}_{3}\right)$, and Campanian-Maastrichtian $\left(\mathrm{K}_{4}\right)$ time (Fig. 10b) tracks magmatism in the adjacent Idaho arc.

Although the Idaho arc was active by $110 \mathrm{Ma}$ (Gaschnig et al., 2010, 2016), the presence of abundant Jurassic grains in northern foreland samples (Fig. 10b) indicates foreland connectivity to a part of the arc affected by Jurassic magmatism, such as the southern Coast Mountains. The influx of $\mathrm{K}_{2}-\mathrm{K}_{3}$ grains during Cenomanian-Santonian time and the simultaneous elimination of Jurassic arc-derived grains (Fig. 10b) is consistent with topographic separation of the foreland from coastal arc sources, likely due to progressive building of the Idaho arc and shortening along the western Idaho shear zone at this time. The sustained presence of $\mathrm{K}_{2}-\mathrm{K}_{3}$ grains in Montana and Wyoming during the Campanian-Maastrichtian (Fig. 10b) signals continued erosion of the pre-85 Ma Idaho arc as voluminous magmatism occurred in the eastern Idaho batholith and adjacent Boulder batholith. It is also possible that $\mathrm{K}_{2}-\mathrm{K}_{3}$ grains were reworked from Cenomanian-Santonian strata that were uplifted in the fold-thrust belt at this time. Lower proportions of $\mathrm{K}_{2}$ $\mathrm{K}_{3}$ grains in Paleocene samples (Fig. 10b) suggest that the pre-85 Ma arc 

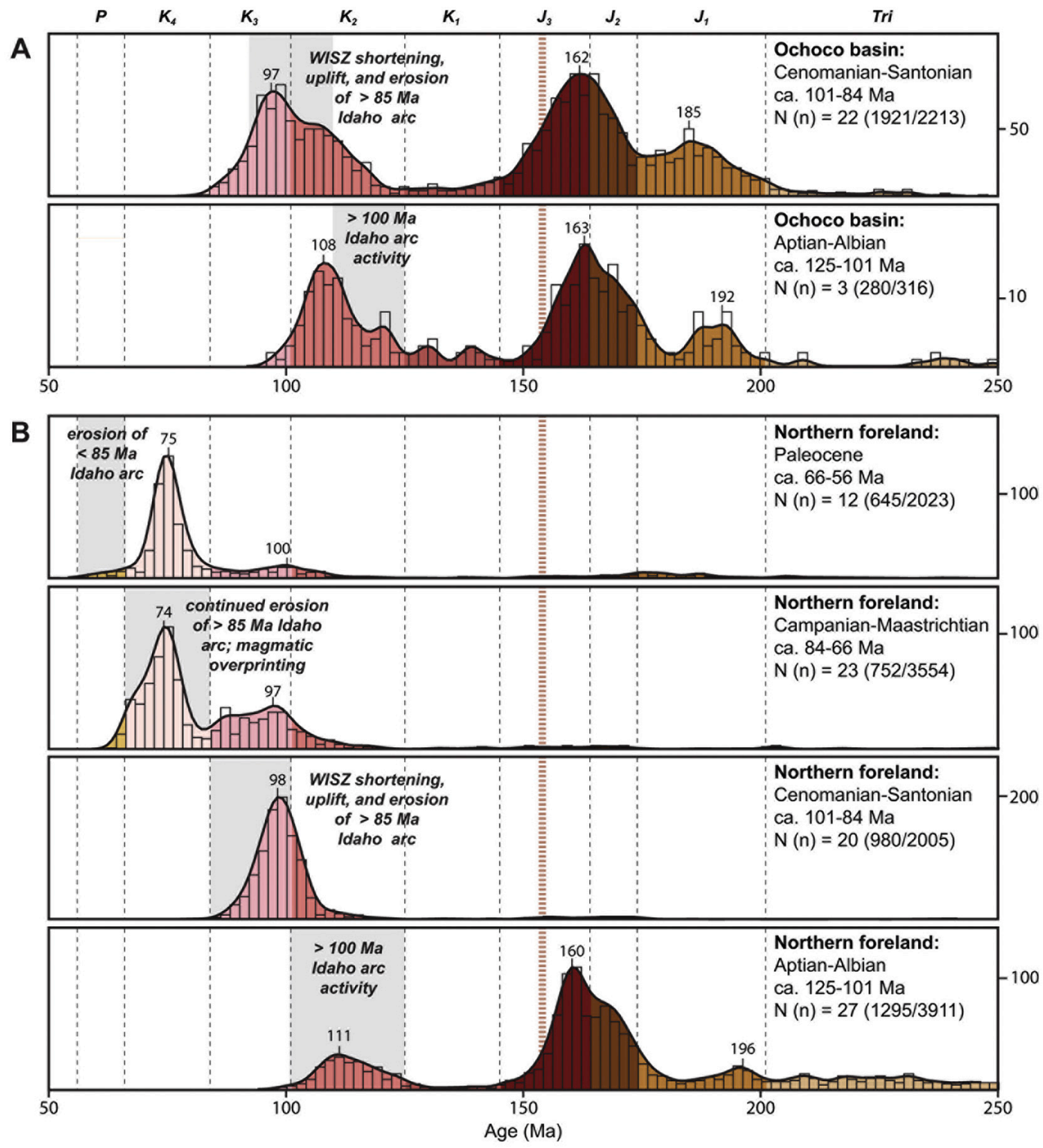

Fig. 10. Histograms and KDEs of composite detrital zircon distributions between 250 and $50 \mathrm{Ma}$ of (A) Aptian-Albian and Cenomanian-Santonian samples from the Ochoco forearc basin and (B) Aptian-Albian, Cenomanian-Santonian, Campanian-Maastrichtian, and Paleocene samples from the northern foreland basin (histogram bin width $=2 \mathrm{Ma}$; KDE bandwidth $=2$ ). Gray shading indicates the timing of early Idaho batholith magmatism during the Aptian-Albian ( 125-100 Ma; after Gaschnig et al., 2016 and based on detrital zircon data presented herein), shortening along the western Idaho shear zone (WISZ) during the Albian-Turonian ( 100-92 Ma; after Giorgis et al., 2005, 2008), erosion and magmatic overprinting of the $>85$ Ma arc during the Turonian-Campanian ( $92-66$ Ma; after Gaschnig et al., 2016) and erosion of the $<85 \mathrm{Ma}$ arc beginning in the Paleocene ( $<66 \mathrm{Ma}$; after Schwartz and Schwartz, 2013). Red, dashed line at $154 \mathrm{Ma}$ indicates the approximate timing of arc integration as suggested by Dickinson et al. (1996), DeCelles (2004), and Surpless et al. (2006). (For interpretation of the references to colour in this figure legend, the reader is referred to the web version of this article.)

had been largely eroded by the end of Cretaceous time, and instead, erosion of the post-85 Ma arc dominated local provenance signatures. Thus, the progression of detrital zircon signatures in the northern foreland provides important insight into the early history of the Idaho batholith.

\subsection{Temporal trends in composite detrital zircon distributions}

\subsubsection{Late Jurassic-Paleocene forearc}

All ages of forearc basin fill contain arc-derived grains (251-56 Ma) and pre-arc grains ( $>251 \mathrm{Ma}$; Fig. 11a). Late Jurassic $\left(\mathrm{J}_{3}\right)$ and Cretaceous $\left(\mathrm{K}_{1}\right.$ through $\left.\mathrm{K}_{4}\right)$ grains dominate the distributions. Pre-arc grains are most abundant in the Late Jurassic $\left(\mathrm{J}_{3} ; 54 \%\right)$ and BerriasianBarremian $\left(\mathrm{K}_{1} ; 39 \%\right)$ sample groups and decrease in abundance in younger sample groups (5-15\% of grains; Fig. 11a). Mirroring the decrease in pre-arc grains, the proportion of arc-derived grains increases upward from the $J_{3}$ to the $K_{1}$ and $K_{2}$ sample groups, and then remains consistent (ranging from 85 to $95 \%$ ) in the $\mathrm{K}_{3}, \mathrm{~K}_{4}$, and Paleocene sample groups (Fig. 11a). The simultaneous decrease in pre-arc grains and the increase in arc-derived grains over time signals 1) progressive growth of the Cordilleran arc, 2) disconnection of the forearc region from major sources of pre-arc zircon, and 3) dilution of pre-arc zircon by voluminous input of arc-derived zircon (e.g., DeGraaff-Surpless et al., 2002; Sharman et al., 2015; Orme and Surpless, 2019).

The composite distributions show upward-younging of arc-derived grains (Fig. 11b), supporting that detritus eroded from volcanic members of the arc was rapidly transported into adjacent forearc basins and/ or erosion of magmatic rocks occurred soon after emplacement. Most 


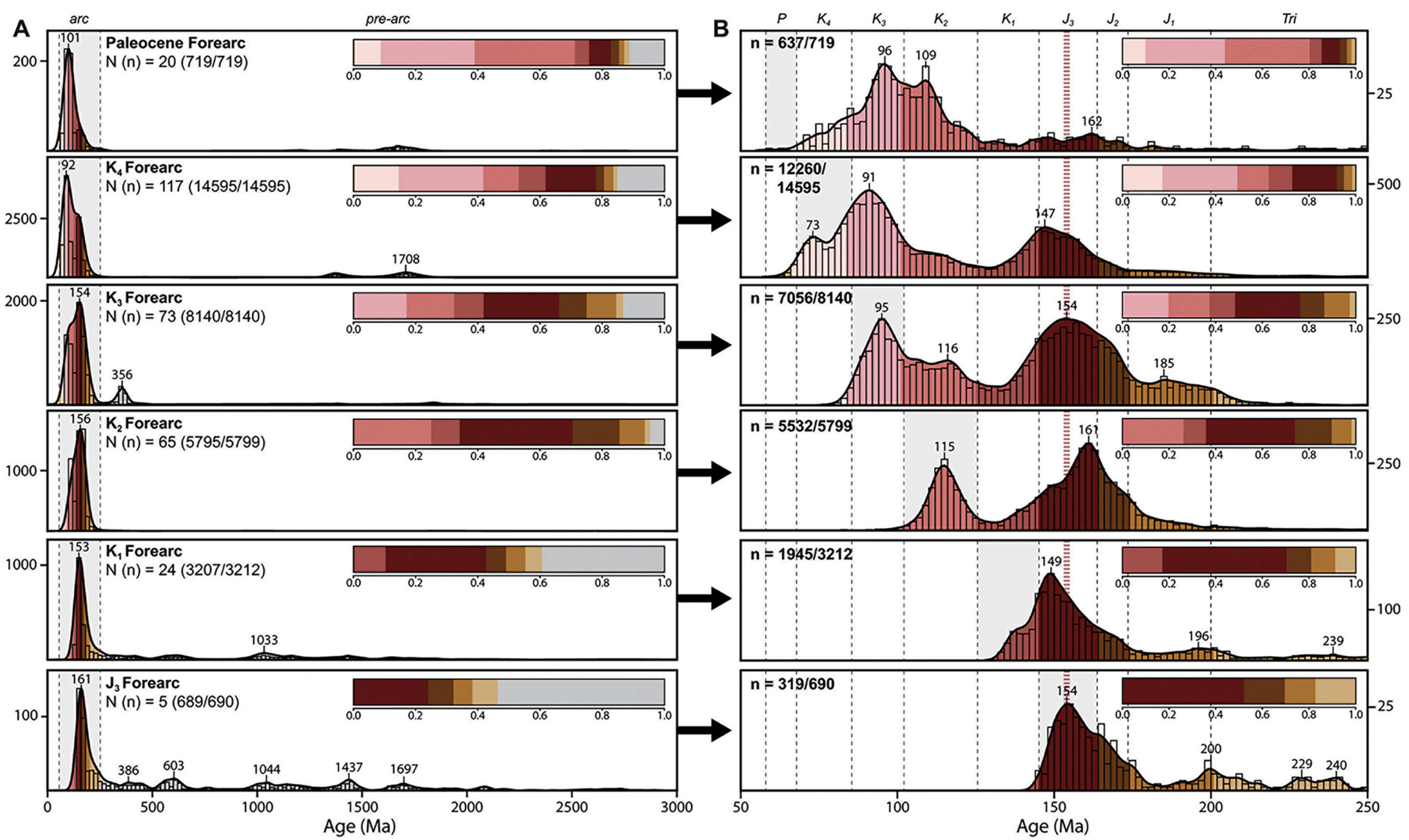

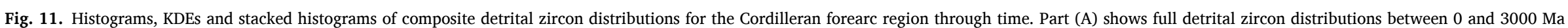

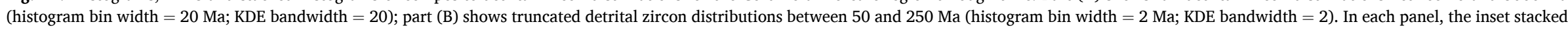

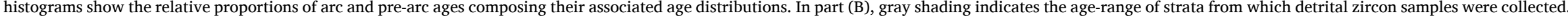

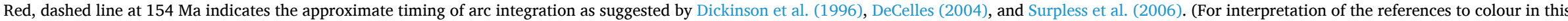
figure legend, the reader is referred to the web version of this article.) 


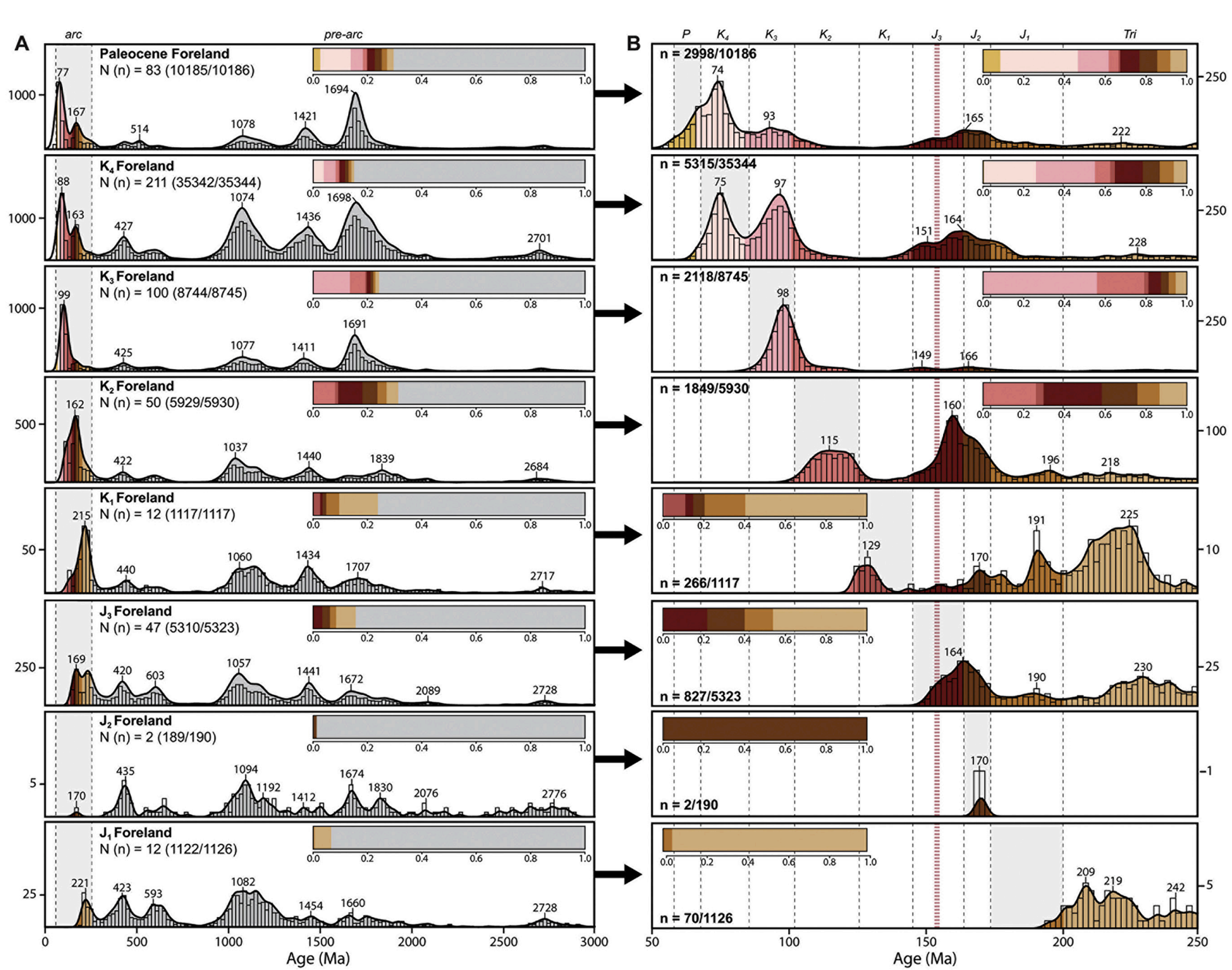

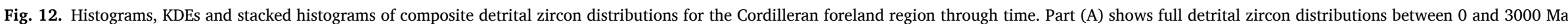

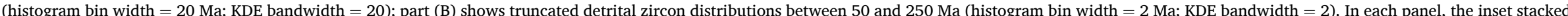

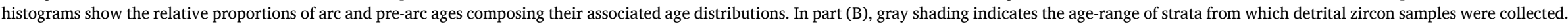

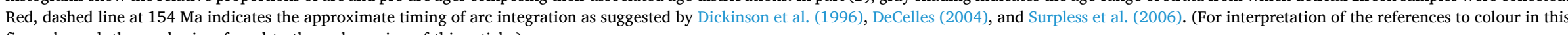
figure legend, the reader is referred to the web version of this article.) 
sample groups are characterized by a prominent, generally Gaussian age mode that coincides with the depositional age of the host sediment, accounting for $15-25 \%$ of all zircon ages in each sample group (Fig. 11b). Two exceptions are the $K_{1}$ and Paleocene distributions: In $K_{1}$, age-equivalent grains are relatively abundant $(10 \%$ of all zircon ages in the distribution; Fig. 11a) but they form the young tail of a Late Jurassic peak, rather than an independent $\mathrm{K}_{1}$-aged peak (Fig. $11 \mathrm{~b}$ ). Notably, the lack of a $\mathrm{K}_{1}$-aged peak is also apparent in the full forearc composite, the foreland composite, and the compilation of in situ zircon ages (Figs. 3f, $6 \mathrm{~b})$, and is consistent with a magmatic lull that has been interpreted for the Sierra Nevada and Coast Mountains batholiths (Ducea, 2001; DeCelles et al., 2009; Gehrels et al., 2009). The Paleocene distribution contains very few Paleocene grains $(n=2$, or $0.2 \%$ of grains from Paleocene samples) that occur on the young tail of a broad Early to Late Cretaceous distribution (Fig. 11b). This indicates that although Paleocene magmatism occurred in some parts of the arc (e.g., Fig. 3a), detritus from those areas was not readily transported to the forearc region during Paleocene time.

Throughout the succession of sample groups, once an age group appears in an age distribution, it generally persists as a substantial component of younger distributions (Fig. 11b). This pattern of addition of progressively younger ages to prior distributions continues through the $\mathrm{K}_{4}$ sample group but is less apparent in the Paleocene group (Fig. 11b) due to a lack of Paleocene grains in the forearc. We suggest that the steady addition of progressively younger zircon to the forearc region reflects continued sedimentary connectivity between forearc basins and active parts of the arc throughout Late Jurassic-Cretaceous time. Given its proximity to forearc basins, the arc remained a source of first-cycle zircon to the basins despite progressive magmatic-volcanic alteration of the arc. We note, however, that even though age groups persist through time, the shapes and apices of specific age peaks vary. For example, the apex of the $J_{3}$-equivalent age peak fluctuates from 147 to $162 \mathrm{Ma}$ through the succession; the age peak is prominent in most sample groups, but becomes diffuse in the Paleocene group (Fig. 11b). Similarly, the $\mathrm{K}_{2}$ and $\mathrm{K}_{4}$ age peaks are obvious when they first occur, but vary in prominence afterward (Fig. 11b). We attribute such variations to changes in exposure and erosion within the arc as drainages evolved with arc topography (e.g., DeGraaff-Surpless et al., 2002; Sharman et al., 2015), as different levels of arc rocks were unroofed, or as younger phases of magmatism-volcanism altered the surface expression of the arc (e.g., Colgan et al., 2018).

\subsubsection{Early Jurassic-Paleocene foreland}

Pre-arc grains ( $>251 \mathrm{Ma}$ ) account for $69-92 \%$ of the foreland basin sample groups (Fig. 12a), highlighting the important role of non-arc sources in providing detrital zircon to the foreland basin. Pre-arc grains are most abundant in Jurassic sample groups (99-84\% in $J_{1}$ through $\mathrm{J}_{3}$ ) and systematically decrease in relative abundance upward through the Lower Cretaceous groups (69\% in $\mathrm{K}_{2}$; Fig. 12a). The proportion of pre-arc grains is then variable in the $\mathrm{K}_{3}, \mathrm{~K}_{4}$, and Paleocene sample groups, accounting for 70-85\% of grains (Fig. 12a). Although the shapes and relative heights of peaks within the pre-arc spectrum vary, the same peaks occur in all age distributions (peaks at $\sim 420,600,1000$, 1400, 1700, and $2700 \mathrm{Ma}$; Fig. 12a). Although some of the age occurrences may reflect first-cycle derivation from North American crustal provinces, most likely represent recycling from metamorphic and sedimentary units exposed in the Sevier hinterland and fold-thrust belt (e.g., Schwartz et al., 2019b). Arc-derived grains account for the remaining grains in each sample group, with proportions increasing upward from $16 \%$ in $\mathrm{J}_{3}$ to $31 \% \mathrm{~K}_{2}$ and then ranging from 15 to $30 \%$ in the $\mathrm{K}_{3}, \mathrm{~K}_{4}$, and Paleocene sample groups (Fig. 12a). We attribute the initial increase in arc-derived grains to elevation gain and the development of topographic relief within the Cordilleran arc, after which sedimentary connectivity to the arc was variable and/or arc-derived zircons were dwarfed by abundant pre-arc zircons.

In the $J_{3}$ and younger sample groups, each successive distribution is characterized by a robust, generally Gaussian age mode that coincides with its depositional age (Fig. 12b). However, the youngest age group is a minor component of each distribution (Fig. 12a), accounting for only $2-13 \%$ of all zircon ages in each group (compared to $15-25 \%$ in the forearc). The $\mathrm{J}_{2}$ through $\mathrm{K}_{4}$ sample groups have discrete young modes that young upward from 170 to $75 \mathrm{Ma}$; Paleocene grains are rare in the Paleocene age group (accounting for $3 \%$ of grain ages) and do not form a unique mode (Fig. 12b).

Individual age peaks do not tend to persist as substantial components of each successive distribution as readily as they do in the forearc region (e.g., Fig. 11b). Instead, the discrete young peak that occurs in each age group is commonly muted to absent in subsequent age groups, such that the $J_{3}$ through Paleocene sample groups tend to be characterized by an isolated young peak trailed by a wide gap in the Cretaceous detrital spectrum (Fig. 12b). We suggest that this trend is related to the primary method of delivery of arc-derived zircon to the foreland basin, a topic we explore in subsequent sections of the discussion. We note that this general pattern is not simply a case of appearance followed by disappearance; for example, a Middle-Late Jurassic peak ( 165-160 Ma) occurs in almost all age groups, and is only minimized in the $K_{1}$ and $K_{3}$ distributions (Fig. 12b). Similarly, the $K_{3}$ and $K_{4}$ peaks do persist in subsequent age groups, composing substantial proportions of younger detrital zircon distributions (Fig. 12b).

It is also notable that Triassic and Jurassic grains are prominent components of the foreland basin distributions, especially in Jurassic $\left(J_{1}\right.$ through $\left.J_{3}\right)$ and Early Cretaceous $\left(\mathrm{K}_{1}\right.$ and $\left.\mathrm{K}_{2}\right)$ sample groups. Triassic grains account for a relatively minor proportion of all grains in the $\mathrm{J}_{1}-\mathrm{K}_{2}$ distributions (up to $14 \%$ ), but compose up to $84 \%$ of arc-derived grains in those distributions (Fig. 12b). Similarly, Early, Middle, and Late Jurassic grains each account for up to $9 \%$ of all grains in the $\mathrm{J}_{1}-\mathrm{K}_{2}$ distributions, but compose up to $33 \%$ of arc-derived grains in those distributions (Fig. 12b). Beginning in the $\mathrm{K}_{3}$ sample group, Triassic and Jurassic grains are less abundant, each accounting for $<10 \%$ of grain ages in $\mathrm{K}_{3}$ through Paleocene sample groups (Fig. 12a). We suggest that the abrupt decrease in the abundance of Triassic and Jurassic grains in Aptian-Albian time reflects overprinting of Triassic-Jurassic arc rocks by Cretaceous magmatism and a disconnection between the foreland and Triassic-Jurassic sources in the Sevier hinterland, likely associated with progressive uplift of the Cordilleran orogen.

\subsection{Implications of spatial and temporal variability in arc-derived grains}

\subsubsection{Evolution of paleogeography and paleodrainage networks}

Spatial and temporal variability in the patterns of detrital zircon age distributions tracks the gradual construction of the arc through magmatic processes; deformation, uplift, and lateral expansion of the Sevier hinterland and fold-thrust belt; and erosion of the orogen. Progressive building of the arc is recorded by a gradual reduction in the signature of pre-arc sources that fed the forearc region, a transition to dominantly arc-derived grains in the forearc, and spatial variability in the presence and ages of arc-derived zircon in the foreland region. Below, we summarize the implications of detrital zircon distributions from the forearc and foreland regions for the topographic and paleogeographic evolution of the Cordilleran orogen. We note that some Cordilleran depocenters have experienced post-depositional geographic modifications (e.g., the Nanaimo, Methow, and borderland forearc basins or foreland basin strata currently exposed within the Sevier foldthrust belt). In the following discussion and in Fig. 13, we either restore (e.g., samples from the fold-thrust belt) or indicate preferred (e. g., samples from the Methow and Nanaimo basins) depositional locations of such sample groups in an effort to best-represent paleogeographic trends in detrital zircon age distributions.

5.3.1.1. Jurassic and Early Cretaceous - Berriasian-Barremian $\left(J_{1}-K_{1}\right.$, 201-125 Ma). Igneous zircon U-Pb ages reveal Jurassic and Berriasian- 


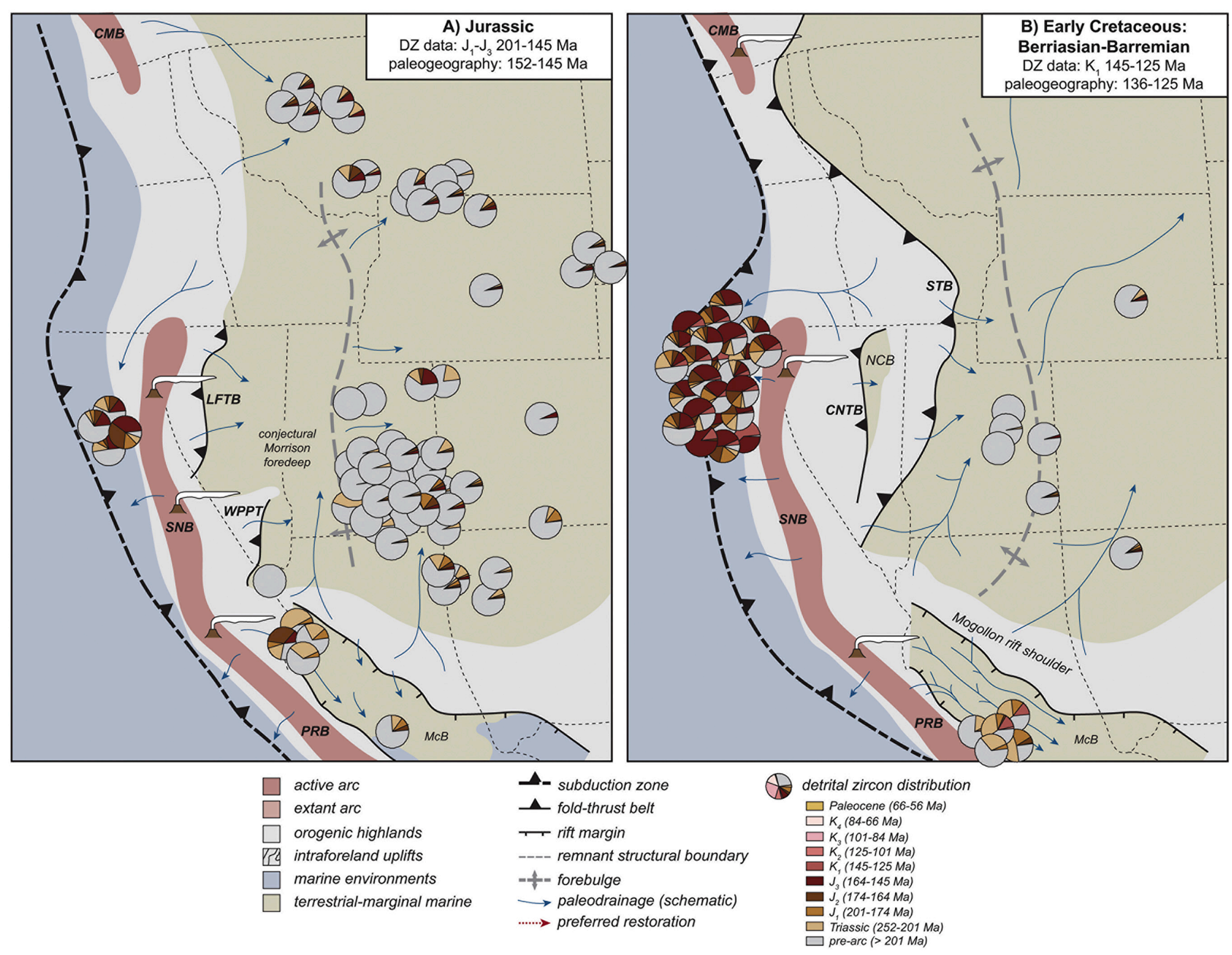




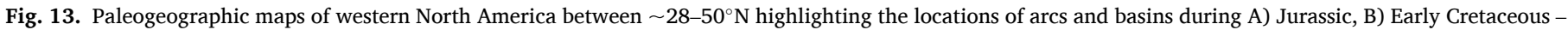

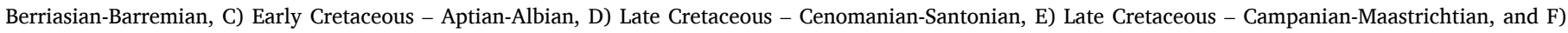

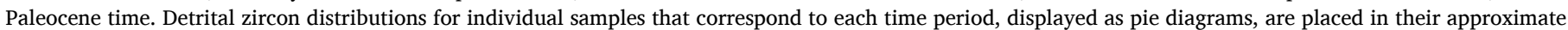

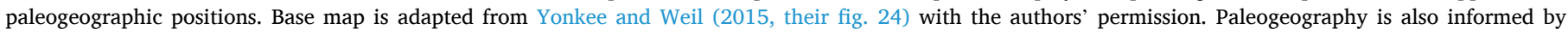

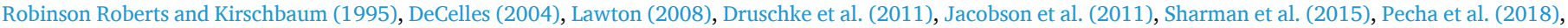

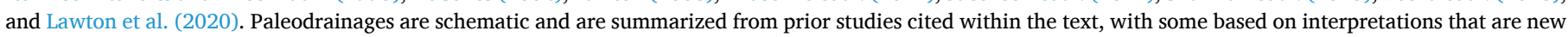

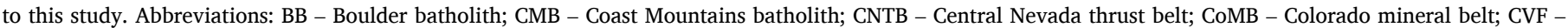

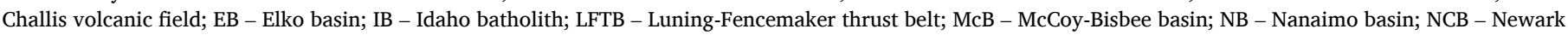

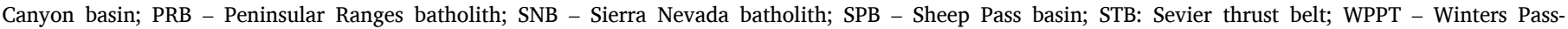
Pachalka thrust.

Barremian magmatism in the Peninsular Ranges, Sierra Nevada, and Coast Mountains batholiths (Fig. 7b-c). The presence of depositional age-equivalent arc-derived grains in Jurassic and $\mathrm{K}_{1}$ detrital zircon samples (Fig. 13a-b) supports active volcanism during that time that would have locally formed constructional topography along the incipient Peninsular Ranges-Sierra Nevada and Coast Mountains arc. An otherwise low-lying and/or discontinuous magmatic arc (e.g., BusbySpera et al., 1990; DeGraaff-Surpless et al., 2002; LaMaskin, 2012; Orme and Surpless, 2019) is supported by the relative abundance of pre-arc grains in Jurassic and $\mathrm{K}_{1}$ detrital zircon samples from the forearc region. Pre-arc grains in forearc samples consistently include peaks at $\sim 400,600,1000,1400$, and $1600 \mathrm{Ma}$, all of which are consistent with ages of North American crustal provinces located east of the evolving arc as well as within the pre-batholithic framework of the arc (e.g., Attia et al., 2018). Zircon derivation from retroarc sources is also supported by the relative abundance of Triassic grains in Jurassic and $\mathrm{K}_{1}$ samples, which were likely derived from Triassic volcanic centers or Triassic sediments exposed in the evolving hinterland region (e.g., Wyld, 2002; Barth and Wooden, 2006; Riggs et al., 2013, 2016).

The incipient arc was also a source of zircon to the foreland region at this time. Abundant Triassic and Jurassic zircon grains in samples from the McCoy-Bisbee basin trend (Fig. 13a-b) are consistent with the formation of a topographically isolated basin sourced locally by the Peninsular Ranges-Sierra Nevada arc on the west and the MogollonBurro rift shoulder on the east (e.g., DeCelles, 2004; Spencer et al., 2011; Lawton et al., 2020). Combined with regional paleoflow indicators, the minor presence of Triassic and Jurassic zircon grains throughout the remainder of the foreland (Fig. 13a-b) also suggests some form of connectivity between the incipient foreland region and the evolving arc (e.g., Dickinson and Gehrels, 2003, 2008, 2009a), consistent with the initiation of a flexural foreland basin during this time (e.g., DeCelles, 2004; Fuentes et al., 2009; May et al., 2013). Throughout Jurassic and into earliest Cretaceous time, however, the relatively lowlying arc was not a major source of sediment to the foreland region; rather, Lower and Middle Jurassic units were dominantly sourced from distant orogenic highlands on the eastern margin of North America, and Upper Jurassic units were largely reworked from underlying Jurassic deposits (Dickinson and Gehrels, 2003, 2009a).

5.3.1.2. Early Cretaceous - Aptian-Albian $\left(K_{2}, 125-101 \mathrm{Ma}\right)$. Igneous zircon $\mathrm{U}-\mathrm{Pb}$ ages document Aptian-Albian magmatism in all arc segments (Fig. 7d). Detrital zircon distributions of Aptian-Albian samples collected throughout the forearc and foreland regions record the emergence of a topographically prominent Cordilleran arc. Although some forearc samples contain substantial proportions of pre-arc zircon throughout Late Cretaceous and Paleocene time (Fig. 13c-f), $\mathrm{K}_{2}$ samples generally highlight an abrupt decrease in the apparent volume of pre-arc zircon reaching the forearc region (Fig. 13c). We argue that this transition reflects drainage reorganization associated with the development of a topographically prominent arc that acted as a primary and local source of sediment to the forearc region (e.g., DeGraaff-Surpless et al., 2002; LaMaskin, 2012; Orme and Surpless, 2019).

Although the Sierra Nevada batholith hosts a strong record of Aptian-
Albian magmatism (e.g., Fig. 3d), coeval detrital zircon samples in the adjacent Great Valley forearc lack $\mathrm{K}_{2}$ grains, which do not become abundant in the Great Valley until Cenomanian-Santonian time $\left(\mathrm{K}_{3}\right.$; Fig. 13c-d). The lack of $K_{2}$ grains in $K_{2}$ samples from the Great Valley forearc may indicate the presence of a drainage divide in the western Sierra Nevada arc, west of the main locus of Aptian-Albian magmatism (e.g., DeGraaff-Surpless et al., 2002; Sharman et al., 2015). At face value, the presence of a Sierran drainage divide is supported by abundant $\mathrm{K}_{2}$ grains in Aptian-Albian samples from the Newark Canyon basin (e.g., Druschke et al., 2011), located to the east of the Sierra Nevada batholith adjacent to the central Nevada thrust belt (Fig. 13c). Alternatively, we posit that the lack of $\mathrm{K}_{2}$ grains in the Great Valley forearc could also indicate a temporary reduction in erosion rates along the Sierra Nevada arc or a lack of an eruptive carapace at that time. $\mathrm{K}_{2}$ grains are common in coeval deposits of the Nanaimo, Methow, and Ochoco forearc basins as well as the northern and southern foreland regions (Fig. 13c), reflecting sources in active parts of the southern Coast Mountains, Idaho, and Peninsular Ranges batholiths (e.g., Druschke et al., 2011; Quinn et al., 2018; Schwartz et al., 2019b; Di Fiori et al., 2020; Finzel and Rosenblume, 2020; Lawton et al., 2020; Ronemus et al., 2020). If the Sierra Nevada batholith did not have an AptianAlbian volcanic carapace or if erosion rates were insufficient to exhume Aptian-Albian arc rocks, it is reasonable that $\mathrm{K}_{2}$ grains in the Newark Canyon basin were delivered by longitudinal drainages emanating from arc sources to the north, such as the Idaho batholith (Fig. 13c).

\subsubsection{Late Cretaceous - Cenomanian-Santonian $\left(K_{3}, 101-84 \mathrm{Ma}\right)$.} Igneous zircon $\mathrm{U}-\mathrm{Pb}$ ages reveal Cenomanian-Santonian magmatism in all arc segments (Fig. 7e). During this time, the axis of magmatism in the Sierra Nevada and Peninsular Ranges migrated eastward (Jacobson et al., 2011; Chapman et al., 2012; Premo et al., 2014) and exhumation of material from great depths occurred in response to isostatic rebound of the arc following gravitational foundering of arc roots (e.g., DeCelles and Graham, 2015). Although the timing, rates, and depths vary, the Peninsular Ranges, Sierra Nevada, and southern Coast Mountains batholiths all experienced rapid Late Cretaceous erosion (beginning ca. 95-90 Ma and lasting until ca. 70-60 Ma) to depths of 10-20 km (e.g., Evernden and Kistler, 1970; Woodsworth, 1979; Ague and Brimhall, 1988; Lovera et al., 1999; Kimbrough et al., 2001; Grove et al., 2003; Colgan et al., 2006; Sharman et al., 2015; Jiang and Lee, 2017). The Idaho-Boulder batholith preserves a slightly different two-phase erosion history including rapid erosion along the western Idaho shear zone from -98-80 Ma (Snee et al., 1995; Giorgis et al., 2008) to depths of perhaps $10 \mathrm{~km}$ (after emplacement depth estimates of Manduca et al., 1993; Zen and Hammarstrom, 1984; Lund and Snee, 1988; Snee et al., 1995; Schmidt and Poli, 2004) followed by rapid erosion of Late Cretaceous plutons of the Boulder batholith to depths of 5-9 km from ca. 66-60 Ma (Houston and Dilles, 2013). Widespread Late Cretaceous erosion of arc rocks resulted in debouching of arc-derived sediment into adjacent basins (e.g., Schwartz and Schwartz, 2013), as shown by abundant arcderived grains of multiple generations throughout the forearc and parts of the foreland (Fig. 13d). 


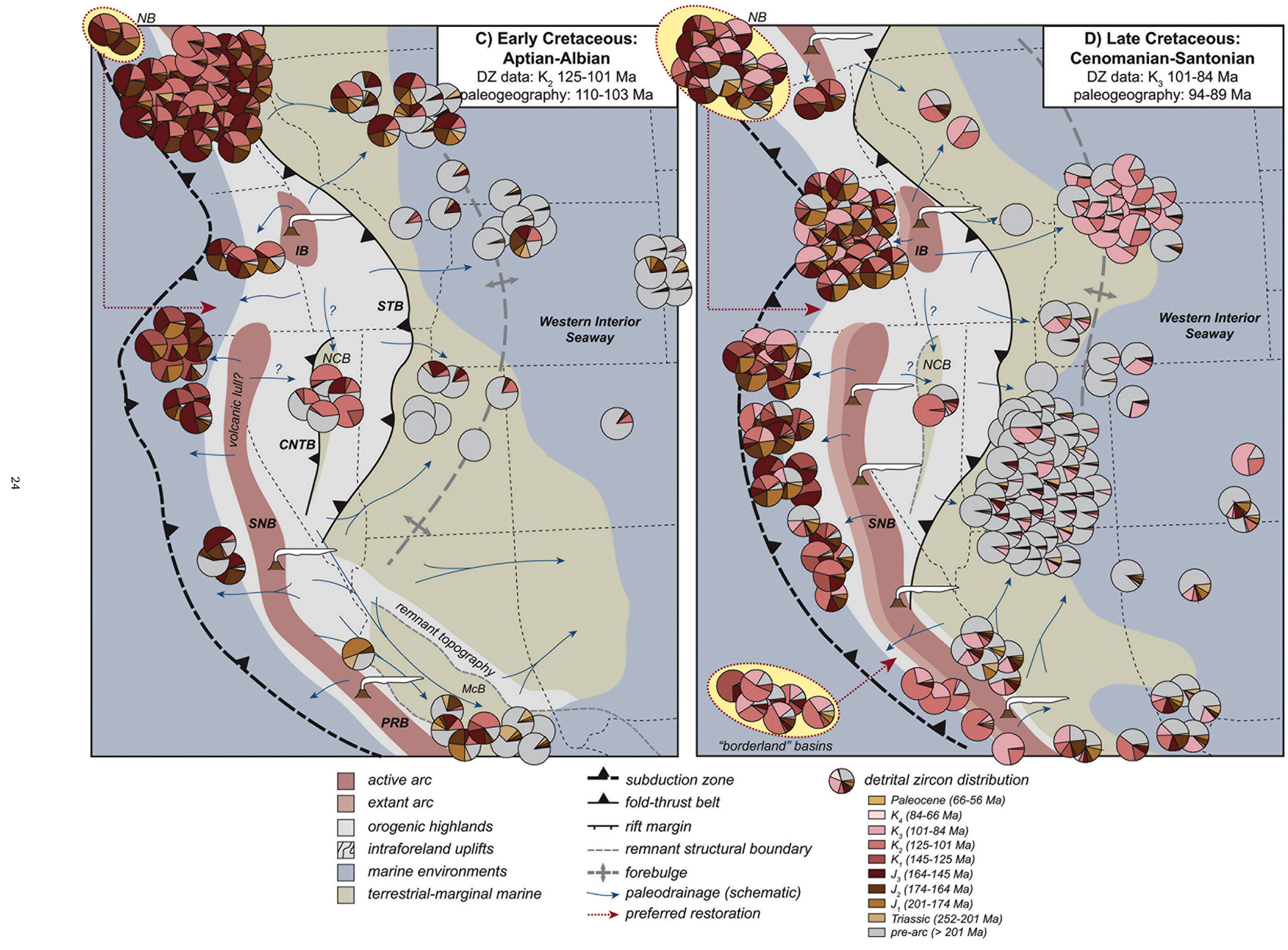

Fig. 13. (continued). 


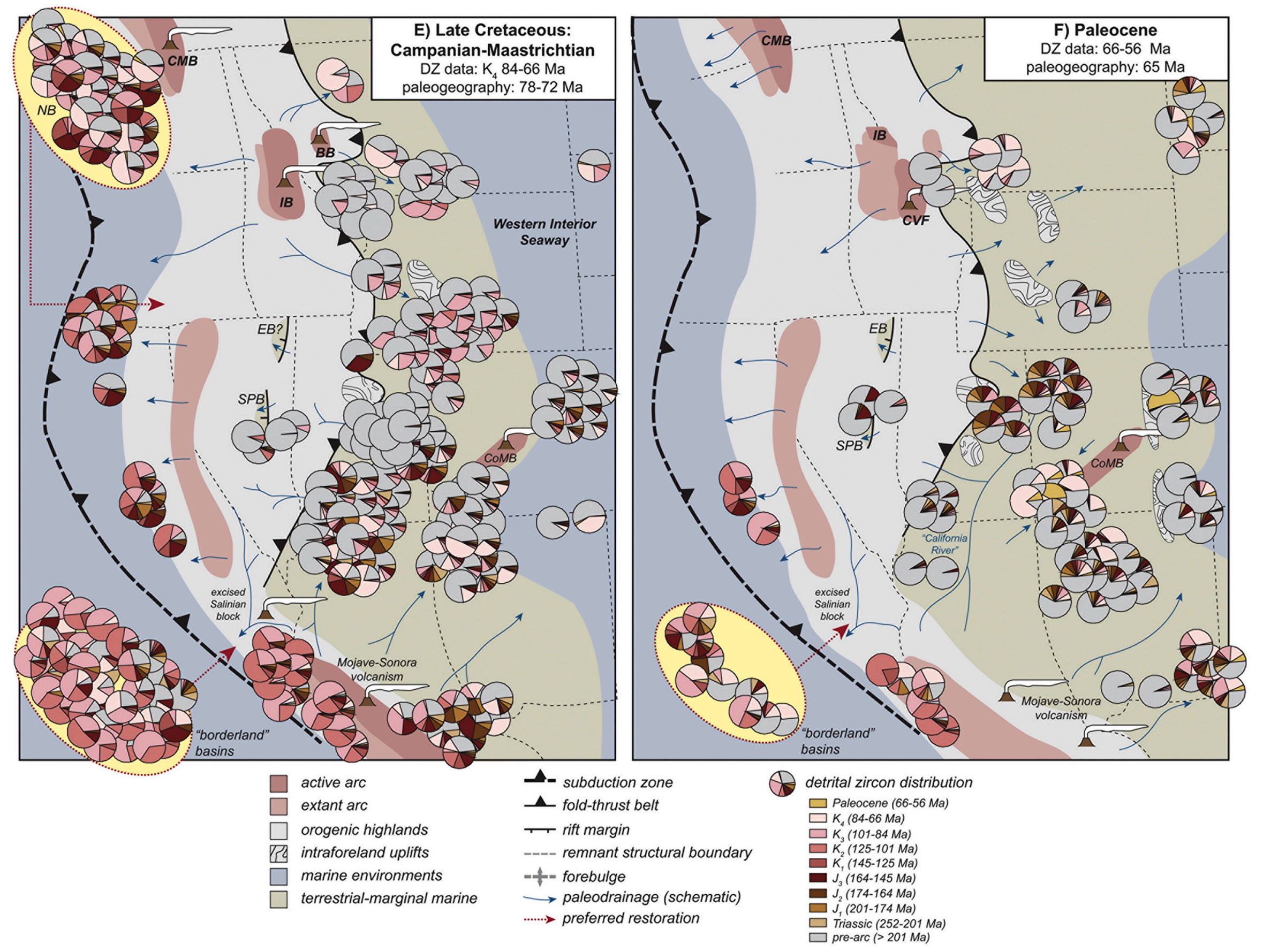


Spatial variability in detrital zircon distributions of $\mathrm{K}_{3}$ samples from the foreland region support uplift and erosion of the arc, but also provide valuable insight into the topographic evolution of the Sevier hinterland and fold-thrust belt. In general, $\mathrm{K}_{3}$ samples from the northern and southern foreland regions are more enriched in arc-derived zircon than their counterparts in the central foreland (Fig. 13d). We suggest that this pattern is largely due to the relative proximity between arc segments and eastward-adjacent foreland depocenters: The northern and southern foreland regions were relatively close to the Idaho and Peninsular Ranges-Sierra Nevada arcs, whereas the central foreland region was separated from the Sierra Nevada arc by the Sevier hinterland and foldthrust belt (e.g., Figs. 1, 2, 13d; DeCelles, 2004; Druschke et al., 2011). The presence of a topographic barrier between the Sierra Nevada arc and central foreland is supported by a dominance of pre-arc grains and general paucity of arc-derived grains in $\mathrm{K}_{3}$ samples from the central foreland (Fig. 13d), as well as an abrupt decrease in Triassic grains that were presumably sourced from western Nevada (Fig. 12b).

Progressive Early to Late Cretaceous arc growth, hinterland deformation, and shortening in the Sevier fold-thrust belt caused uplift of those terranes into a wide orogenic highland by Cenomanian-Santonian time (i.e., the Nevadaplano; DeCelles, 2004). Hinterland deformation, including magmatism and metamorphism at depth and shallower, broad crustal folding, resulted in progressive surface uplift as crustal thicknesses approached 40-50 km (Colgan and Henry, 2009), possibly reaching 65-70 km (Long, 2019). Hinterland uplift was synchronous with rapid eastward expansion of the fold-thrust belt (DeCelles, 2004), resulting in a wide and topographically prominent orogenic highland. Surface uplift of the hinterland and fold-thrust belt limited or blocked fluvial transport of zircon from the arc to the foreland, and in turn became a source of recycled zircons with North American basement ages throughout its evolution (e.g., Painter et al., 2014). The presence of a broad topographic barrier at the latitude of Nevada-Utah explains the general dominance of pre-arc grains, the corresponding paucity of arcderived grains, and the lack of abundant Triassic grains in samples from the central foreland. In contrast, while there was undoubtedly topographic relief related to the Idaho-Boulder and northern Peninsular Ranges-southern Sierra Nevada arcs at this time, their associated deformation belts were narrower, allowing for fluvial connectivity between the arcs and foreland depocenters (Fig. 13d; e.g., Schwartz et al., 2019b; Lawton et al., 2020).

5.3.1.4. Late Cretaceous - Campanian-Maastrichtian $\left(K_{4}, 84-66 \mathrm{Ma}\right)$. While the Sierra Nevada batholith was extinguished in CampanianMaastrichtian time due to shoaling of the Farallon plate (e.g., Livaccari et al., 1981; Henderson et al., 1984; Barth and Schneiderman, 1996; Saleeby, 2003), igneous zircon U-Pb ages reveal continued CampanianMaastrichtian magmatism in the Idaho-Boulder and southern Coast Mountains batholiths (Fig. 7f). Magmatism also persisted in the Mojave Desert and Sonora, Mexico (e.g., Wells et al., 2012; Gonzales-Leon et al., 2000; McDowell et al., 2001), and initiated within the foreland in the Colorado mineral belt (Fig. 13e; Chapin, 2012). As such, detrital zircon distributions in the forearc and foreland reflect continued building of topography in some sectors of the arc, but record the erosional degradation of the arc in other areas.

Detrital zircon samples from all forearc depocenters reflect continued erosion of the arc, shown by diverse arrays of arc-derived grains (i.e., samples contain admixtures of Jurassic and $\mathrm{K}_{1}$ through $\mathrm{K}_{3}$ or $\mathrm{K}_{4}$ grains; Fig. 13e). The Great Valley and Hornbrook forearc basins received rare $\mathrm{K}_{4}$ grains, reflecting predominantly local derivation from the eroding Sierra Nevada-Klamath arc (Sharman et al., 2015). The borderland and Nanaimo basins, on the other hand, received substantial volumes of $\mathrm{K}_{4}$ grains (Fig. 13e), indicating connectivity between active volcanic centers and the forearc region. In addition to abundant $\mathrm{K}_{4}$ grains, Campanian-Maastrichtian samples from the borderland basin system also contain Triassic and pre-arc grains, demonstrating input by retroarc source areas including latest Cretaceous plutons in the Mojave desert and northern Sonora, Jurassic plutons in the eastern Sierra Nevada, and pre-arc rocks exposed on the shoulder of the Mogollon highlands (after Jacobson et al., 2011; Sharman et al., 2015).This transition to back-arc sources coincides with the tectonic removal of arc and forearc terranes along the strike-slip Nacimiento fault system (after Jacobson et al., 2011).

Campanian-Maastrichtian samples from the foreland region generally contain more abundant arc-derived grains than their CenomanianSantonian counterparts, but remain dominated by pre-arc grains. Samples from the southern and south-central foreland regions consistently contain relatively abundant Triassic and Jurassic grains, with many samples also containing abundant $\mathrm{K}_{4}$ grains $\left( \pm \mathrm{K}_{3}\right.$ and $\mathrm{K}_{2}$ grains; Fig. 13e). This pattern is maintained across the south-central foreland and northward into central Utah and eastern Colorado (Fig. 13e). A group of samples from central Utah, adjacent to the thrust front, are devoid of arc-derived zircon and contain only pre-arc grains (Fig. 13e), indicating limited pre-arc sources within the fold-thrust belt. To the north, samples from southern and central Wyoming contain relatively abundant arc-derived grains (dominantly $\mathrm{K}_{3}$ and $\mathrm{K}_{2}$ grains with minimal $\mathrm{K}_{4}$ grains) but only rare Triassic and Jurassic grains (Fig. 13e). Even further north in Montana, samples contain variable proportions of $\mathrm{K}_{2}$ through $\mathrm{K}_{4}$ grains and lack Triassic-Jurassic grains altogether (Fig. 13e).

We suggest that the variability in detrital zircon distributions across the foreland reflects the existence of multiple large drainages systems that connected various parts of the arc complex with the foreland region. In the southern foreland, south of influence of the Nacimiento fault system, drainages likely emanated from the Peninsular Ranges into northern Mexico and were affected by incipient Laramide uplifts (Fig. 13e; after Lawton and Bradford, 2011; Gonzales-Leon et al., 2017; Lawton et al., 2020). These southernmost foreland depocenters were likely isolated from the foreland region to the north, which was fed by transverse drainages originating in the Mogollon highlands and Sevier fold-thrust belt, many of which merged to form axial drainages that flowed sub-parallel to the Sevier deformation front and/or around incipient Laramide uplifts (Fig. 13e; e.g., Jinnah et al., 2009; Lawton et al., 2010; Szwarc et al., 2015; Pecha et al., 2018; Pettit et al., 2019; Beveridge et al., 2020). $\mathrm{K}_{4}$ grains throughout the southern and southcentral foreland were likely derived from Laramide magmatic centers in the Mojave Desert and Sonora, Mexico, as well as the oldest parts of the Colorado mineral belt in southwest Colorado. A pattern of transverse drainages originating in the Sevier thrust front and coalescing in the foreland interior, with further downstream transport influenced by emerging Laramide uplifts, is apparent throughout the remainder of the central foreland region (e.g., May et al., 2013; Bush et al., 2016; Lynds and Xie, 2019; Garber et al., 2020; Pujols et al., 2020). In the northern foreland, samples from throughout Wyoming and Montana containing abundant $\mathrm{K}_{3}$ and/or $\mathrm{K}_{4}$ grains (with lesser $\mathrm{K}_{2}$ grains) record erosion of the Idaho-Boulder batholith that was concurrent with Laramide deformation and uplift across southwestern Montana (e.g., Houston and Dilles, 2013; Schwartz et al., 2019a).

5.3.1.5. Paleocene (66-56 Ma). Limited igneous zircon U-Pb ages reveal Paleocene magmatism in the southern Coast Mountains and Idaho batholiths (Fig. 7g); Paleocene magmatism also occurred in the Colorado Mineral belt (Fig. 13f). In general, Paleocene detrital zircon samples from the forearc and foreland regions reflect continued erosion of the arc complex as magmatism waned and deformation was transferred into the foreland region (e.g., DeCelles, 2004; Copeland et al., 2017). Although Paleocene samples from the forearc region are few, detrital zircon distributions from the Great Valley forearc indicate continued erosion of the Sierra Nevada arc (e.g., Sharman et al., 2015). The lack of Paleocene grains in the forearc region at this time (e.g., Fig. 13f) indicates that the Great Valley forearc was disconnected from Paleocene eruptive centers in Idaho and the southern Coast Mountains, even though connectivity to 


\section{A. Cenomanian-Santonian, Great Valley \& Hornbrook basins}

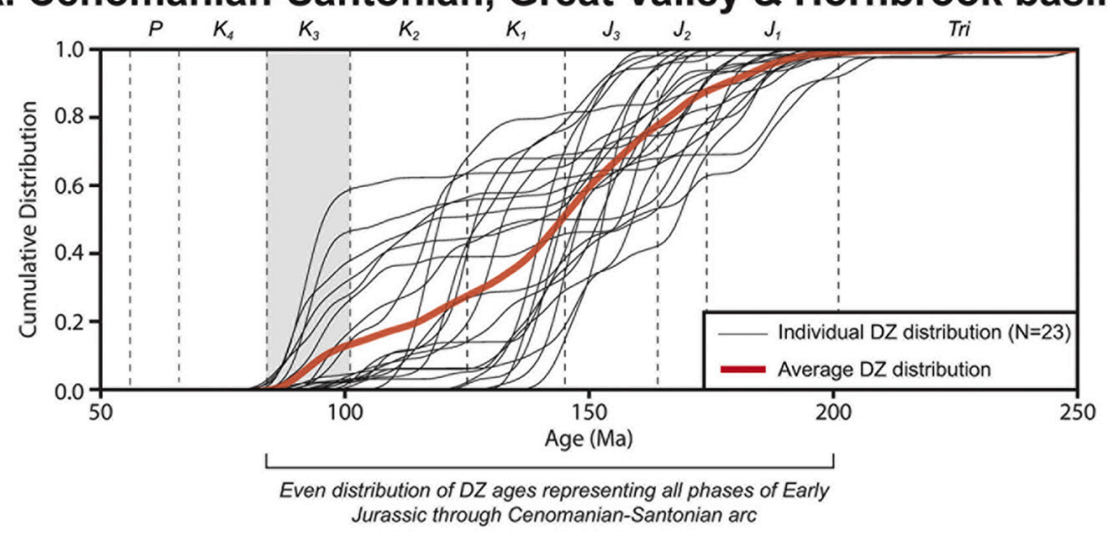

\section{B. Cenomanian-Santonian, Central Foreland Basin}

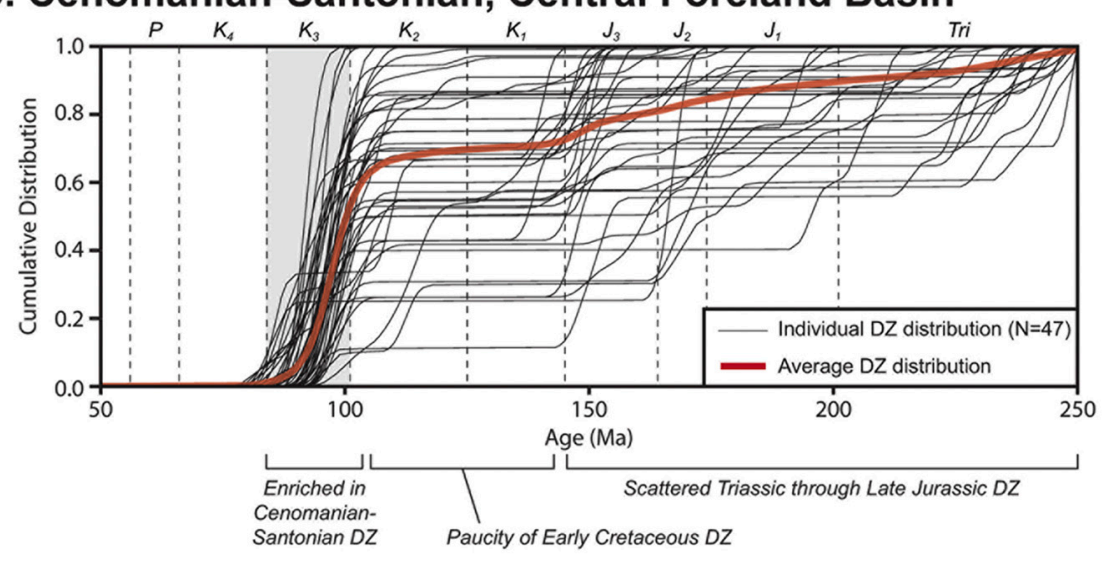

Fig. 14. Comparison of cumulative KDEs (CDKEs) for Cenomanian-Santonian detrital zircon samples from (A) the Great Valley and Hornbrook forearc basins and (B) the central foreland basin, trimmed to only show arc-derived zircon ages between 50 and $250 \mathrm{Ma}$ (CKDE bandwidth $=2$ for all curves). Gray shading indicates the age-range of strata from which detrital zircon samples were collected. CKDEs for forearc samples show relatively even distributions of Early Jurassic-Late Cretaceous grain ages, interpreted herein to reflect fluvial transport of sediment to the basin. In contrast, CKDEs for foreland samples are enriched in Cenomanian-Santonian ages, lack Early Cretaceous, and contain variable (but small) proportions of Triassic-Jurassic ages, interpreted herein to reflect ash-fall events (Cenomanian-Santonian ages) and recycling of strata in the fold-thrust belt (Triassic-Jurassic ages). the Idaho batholith and Challis volcanic field has been established for the Eocene Great Valley and Tyee basins (e.g., Dumitru et al., 2013, 2016). Paleocene samples from the borderland basin system mimic Campanian-Maastrichtian samples, containing substantial proportions of pre-arc, Jurassic, and $\mathrm{K}_{4}$ grains, indicating continued connectivity to the back-arc region (Fig. 13f; Jacobson et al., 2011).

Paleocene samples from the foreland also mimic their CampanianMaastrichtian predecessors in that they are dominated by pre-arc grains and there is substantial intra-foreland variability in the proportions of arc-derived grains (Fig. 13f). Although arc magmatism had ceased in many parts of the arc by the Paleocene, Paleocene zircons occur sporadically across the foreland region, focused in western North Dakota, across Colorado, and in west Texas (Fig. 13f). Their local abundance likely reflects their proximity to Paleocene eruptive centers in the Idaho batholith-Challis volcanic field (Gaschnig et al., 2010) and the Colorado mineral belt (e.g., Stein and Crock, 1990; Chapin, 2012). The presence of all other arc-derived grains is highly variable across the foreland region. Samples in the southern foreland vary from mostly prearc grains in Arizona, 25-50\% arc-derived grains throughout New Mexico, to mostly arc-derived grains in west Texas (Fig. 13f). Samples from the central foreland contain relatively abundant Triassic-Jurassic grains and variable proportions of $\mathrm{K}_{1}$ through $\mathrm{K}_{4}$ grains, wherein $\mathrm{K}_{4}$ grains are especially abundant in central New Mexico and southwest Colorado adjacent to the Colorado mineral belt (Fig. 13f). Samples from the northern foreland tend to contain abundant $\mathrm{K}_{4}$ grains with fewer $\mathrm{K}_{3}$ and $\mathrm{K}_{2}$ grains, indicating continued erosion of the Idaho-Boulder batholith as it was uplifted and incised during Paleocene time (Houston and Dilles, 2013; Schwartz and Schwartz, 2013). Altogether, the high degree of lateral variability within the foreland region likely reflects the partitioning of drainages related to the progressive, diachronous uplift of Laramide intraforeland structures (e.g., Davis et al., 2009; Dickinson et al., 2012; Bush et al., 2016; Li and Fan, 2018; Pecha et al., 2018; Sharman et al., 2018b; Lynds and Xie, 2019).

\subsubsection{Sediment transport mechanisms: fluvial vs. aerial delivery}

The spatial and temporal variations in the proportions of arc-derived zircon described above permit discussion of the extent to which arcderived zircon is delivered to adjacent basins through volcanogenic versus alluvial-fluvial processes (e.g., Fig. 2). Volcanogenic processes include events such as pyroclastic flows, lahars, or ash falls; pyroclastic flows and lahars may deposit volcanogenic sediment up to a few hundred kilometers from source volcanos, whereas ash may be aerially transported hundreds to thousands of kilometers (Myers and Brantley, 1995). These processes are event-based and occur at discrete points in time. Other surface processes such as weathering, erosion, and alluvialfluvial transport of loose sediment are ongoing and may incorporate arcderived detritus at the arc proper and/or may remobilize volcanogenic deposits on the periphery of the arc, facilitating transport into adjacent basins. Sediments may then be redistributed within those basins by additional terrestrial and/or marine sediment transport processes (e.g., Fig. 2).

We interpret the roles of volcanogenic and alluvial-fluvial processes in the delivery of arc-derived zircon to adjacent basins using the following six premises: 1) If arc-derived zircon is delivered to a basin by volcanogenic processes, zircon crystals in those deposits are likely to have consistent ages; however, there may be spread in ages due to the presence of xenocrysts, incorporation of older volcanic wall rock during eruption, or incorporation of non-volcanic rock fragments during transport. 2) After deposition, volcanogenic deposits may be remobilized by alluvial-fluvial processes. 3) If arc-derived zircon is delivered to a basin by alluvial-fluvial processes, all zircon-bearing arc rocks exposed in a given catchment should ideally be represented in that sediment. 4) 

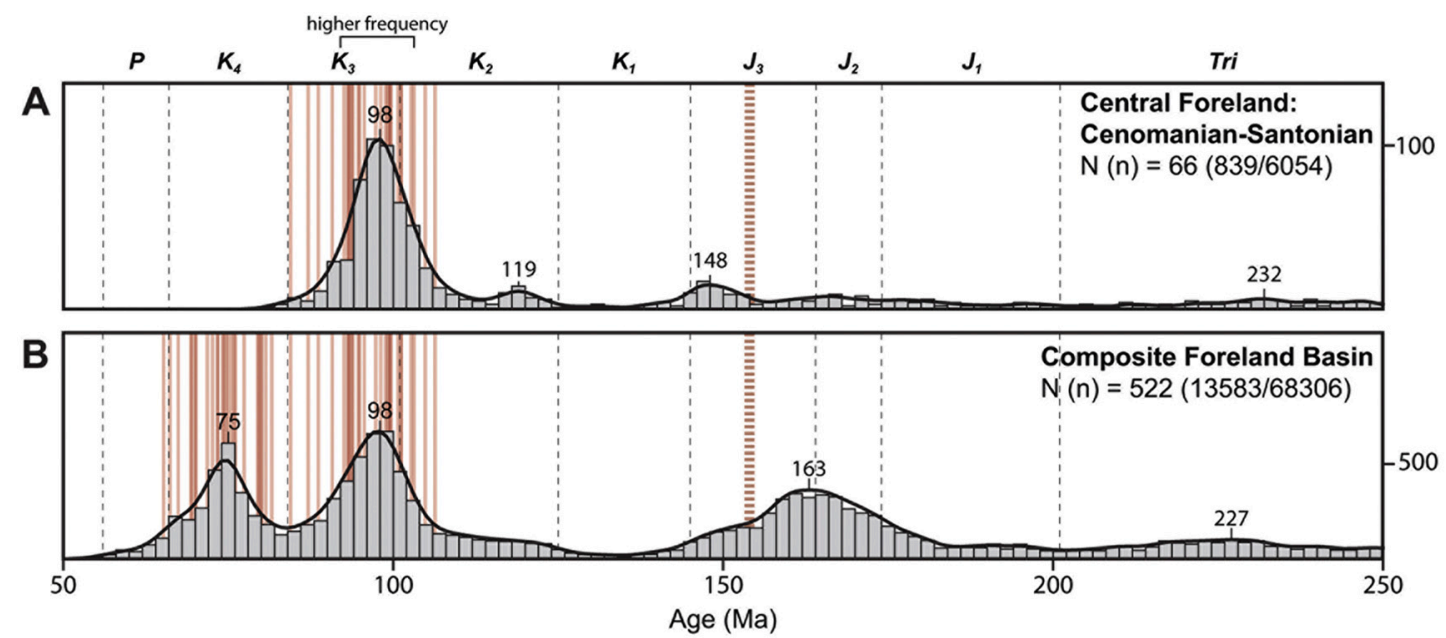

Fig. 15. Correlation of the known ${ }^{40} \mathrm{Ar} /{ }^{39} \mathrm{Ar}$ ages of bentonites (vertical red lines) from Upper Cretaceous marine and marginal marine deposits of the Western Interior with A) the detrital zircon distribution of Cenomanian-Santonian samples in the central foreland region and B) the composite foreland distribution (histogram bin width = 2 Ma; KDE bandwidth = 2). Bentonite data are from Rogers et al. (1993), Hicks et al. (1999, 2002), Foreman et al. (2008), Merewether et al. (2011), and Singer et al. (2020). Red, dashed line at 154 Ma indicates the approximate timing of arc integration as suggested by Dickinson et al. (1996), DeCelles (2004), and Surpless et al. (2006). (For interpretation of the references to colour in this figure legend, the reader is referred to the web version of this article.)

However, during transport, dilution of grain ages by a widely exposed or particularly zircon-enriched source rock may occur (e.g., Malkowski et al., 2019; Schwartz et al., 2019b). 5) With downstream transport, especially as watersheds converge, sediment mixing should occur such that detrital zircon distributions become more complex, generating a mixture of arc and non-arc ages (e.g., Malkowski et al., 2019). During transport, recycling of older basin deposits may result in the reintroduction of poly-cycle arc-derived sediment to the most recent phase of the basin (e.g., Capaldi et al., 2017). 6) Although sediment mixing and/or dilution may complicate detrital zircon distributions, preferential removal of any one age group is unlikely to occur.

5.3.2.1. Fluvial delivery of zircon to the forearc and foreland. Fluvial paleodispersal is perhaps the most discussed or implied mode of transport for delivering detrital zircon grains from source rocks to basins. In many cases, such an interpretation is grounded in the fact that detrital zircon samples are collected directly from fluvial deposits (e.g., Lawton et al., 2010; Szwarc et al., 2015; Bartschi et al., 2018; Pettit et al., 2019; Pujols et al., 2020). In other cases, fluvial transport to a basin is implied by an inferred genetic association between non-fluvial deposits such as deltaic, shoreface, or deep marine deposits and the up-slope fluvial systems that had to have fed them (e.g., DeGraaff-Surpless et al., 2002; Sharman et al., 2015; Bartschi et al., 2018; Pettit et al., 2019; Coutts et al., 2020).

Jurassic-Paleocene samples from the forearc region indicate that arcderived sediment was delivered to forearc basins via fluvial processes prior to being redistributed by marine processes. For any suite of detrital zircon samples shown in Fig. 13, most samples from the forearc show well-mixed distributions of zircon ages; some samples contain both prearc grains and arc-derived grains, whereas others only contain arcderived grains. Arc-derived grains are characterized by a diverse mixture of grain ages that span the history of the arc leading up to the time of deposition (Fig. 14); Jurassic ( $\mathrm{J}_{1}$ through $\mathrm{J}_{3}$ ) and Cretaceous $\left(\mathrm{K}_{1}\right.$ through $\mathrm{K}_{4}$ ) grains are most common, but Triassic grains also occur. In any single time period, forearc samples contain age-equivalent arcderived grains as well as multiple generations of older arc-derived grains (Fig. 14); this pattern mimics the composite detrital zircon trends shown in Fig. 11, which highlights the steady addition and sustained presence of each age group through time. We argue that the persistent representation of multiple generations of arc rocks supports erosion and fluvial transport of sediment from the arc to the forearc region, during which mixing of zircons from multiple source areas could occur without preferential loss of any given age group.

5.3.2.2. A case for aerial delivery to the foreland. Detrital zircon distributions of Cretaceous through Paleocene samples from the northern and southern foreland regions mimic the detrital zircon distributions of the forearc in that samples contain a mixture of pre-arc and arc-derived grains, and of those arc-derived grains, multiple age groups are commonly represented (Fig. 13c-f). Certainly, the foreland region was fed by fluvial systems draining orogenic highlands (e.g., Lawton et al., 2010; Bartschi et al., 2018; Pettit et al., 2019; Pujols et al., 2020), during which mixing of arc-derived and pre-arc zircons could occur if both sources were exposed in headwater regions. However, CenomanianSantonian samples in the central foreland generally contain very few arc-derived grains (typically $<25 \%$ of the full age distribution), and those that do exist include depositional age-equivalent $\left(\mathrm{K}_{3}\right)$ grains, Jurassic-Triassic grains, and only rare Early Cretaceous grains (i.e., $\mathrm{K}_{1}$ and $K_{2}$ ) (Fig. 13d, 14). Further, when $K_{2}$ grains do occur, they tend to form the older tails of peaks that span the $\mathrm{K}_{2}-\mathrm{K}_{3}$ transition (Fig. 14). We argue that the presence of only $\mathrm{K}_{3}$, Jurassic, and Triassic grains and the preferential absence of $\mathrm{K}_{1}$ and $\mathrm{K}_{2}$ grains in Cenomanian-Santonian samples of the central foreland region supports aerial delivery of arcderived zircon to the region. In this context, we infer that $\mathrm{K}_{3}$ grains were delivered to the foreland by ash fall, whereas Triassic-Jurassic grains were likely derived from Triassic-Jurassic sedimentary units exhumed in the evolving fold-thrust belt.

Cenomanian-Santonian eastward expansion of the Sevier fold-thrust belt (DeCelles, 2004; DeCelles and Graham, 2015) incorporated and cannibalized earlier foreland basin sediments (DeCelles, 1994; Talling et al., 1995; DeCelles, 2004; DeCelles and Coogan, 2006) and disconnected the Sierra Nevada arc from the central foreland region through the building of an orogenic plateau, commonly referred to as the Nevadaplano (DeCelles, 2004; Druschke et al., 2011; Snell et al., 2014). The orogenic plateau became a topographic barrier between the Sierra Nevada arc and central foreland region and provided a mechanism to recycle Triassic-Jurassic zircon grains from Triassic-Jurassic strata.

Concurrently, Cenomanian-Santonian time was characterized by high-flux magmatism in the Peninsular Ranges, Sierra Nevada, southern Coast Mountains, and possibly the Idaho batholith (Fig. 3b-e; Ducea, 2001; DeCelles et al., 2009; Gaschnig et al., 2016). The presence of thick bentonite deposits throughout Upper Cretaceous marine and marginal 
marine deposits of the Western Interior provides evidence that eruptive events in the arc influenced deposition in the foreland region. Due to easterly prevailing wind directions, eruptions caused ash-fall events across the foreland region (Elder, 1988; Scarberry et al., 2020; Singer et al., 2020). High-precision ${ }^{40} \mathrm{Ar} /{ }^{39} \mathrm{Ar}$ ages of bentonites in the Western Interior document eruptions between $\sim 106$ and $65 \mathrm{Ma}$, with apparent variability in the frequency of eruptive events (Fig. 15). We posit that for every bentonite preserved in marine sectors of the basin, there was likely an equivalent blanket of ash across upwind terrestrial environments. Ash deposited in the terrestrial realm could have been preserved on floodplains and incorporated into soils, but ash deposited across orogenic highlands was likely remobilized with phenocrysts fractionated into sand-bearing deposits. Fig. 15 shows a clear correlation between high-frequency eruptive events and prominent detrital zircon peaks at $\sim 98$ and $75 \mathrm{Ma}$, providing additional evidence that $\mathrm{K}_{3}$-aged zircon grains in Cenomanian-Santonian strata of the central foreland were sourced by ash fall, rather than by surface processes, and further explaining the lack of older Cretaceous grains (i.e., $K_{1}$ and $K_{2}$ ) in those samples. This interpretation shows that the presence of arc-derived grains alone does not require surficial connectivity to an arc source.

\section{Summary \& conclusions}

Our compilation of detrital zircon U-Pb data allows for an orogenscale assessment of arc magmatism and sediment dispersal during Jurassic-Paleocene growth of the North American Cordilleran arc. By investigating detrital zircon U-Pb ages between 251 and 56 Ma preserved in Cordilleran forearc and foreland basin strata, we effectively isolate zircon grains that were dominantly derived first-cycle from the arc, thereby enabling a comparison of detrital zircon distributions to available igneous zircon $\mathrm{U}-\mathrm{Pb}$ ages that independently characterize the arc. We conclude the following:

1. Cordilleran forearc and foreland basins contain different proportions of arc-derived zircon. All samples considered together, the forearc is strongly dominated by arc-derived grains (251-56 Ma) and the foreland is strongly dominated by pre-arc grains ( $>251 \mathrm{Ma}$ ). In both basin systems, proportions of arc-derived grains are spatially and temporally variable.

2. Basin fills are thus long-term archives of zircon production, and by extension, arc activity. The detrital record avoids the preservation bias of igneous zircon U-Pb ages by providing space- and timeintegrated records of crystallization ages, but at the expense of age precision.

3. The age distribution of compiled detrital zircon data generally mirrors igneous zircon U-Pb ages and supports a continuous history of Mesozoic-early Cenozoic arc magmatism beginning in Triassic time. Detrital zircon age peaks between 251 and 56 Ma correlate well with known periods of high magmatic flux, suggesting that prominent peaks in the detrital record reveal high-flux events (HFEs) in adjacent arcs. Based on this premise, we identify a potential, previously unrecognized HFE at $\sim 114 \mathrm{Ma}$.

4. The age distribution of compiled detrital zircon data records phases of arc history that are no longer well-preserved by arc rocks. For example, we interpret abundant Early to Late Cretaceous detrital zircon ages in samples from the northern foreland region to record emplacement, uplift, and erosion of the Idaho batholith prior to 85 Ma, supporting the presence of an Early Cretaceous arc at that latitude.

5. Considered at the orogen scale, spatial variability in the detrital zircon distributions of individual samples highlights source-to-sink relationships that are otherwise difficult to document. Detrital zircon provenance patterns reveal obvious connectivity between the arc and forearc, but variable connectivity between the arc and foreland. Variability in the proportions of different arc-derived grain ages suggests that paleodispersal pattens were largely dictated by the topographic evolution of the arc.

6. Paired with interpretations of orogenic processes and paleotopography, spatial variability in detrital zircon distributions holds important implications for the mechanisms that transported sediment from the arc to adjacent basins. Detrital zircon distributions from the forearc characterized by arc-derived zircon of diverse ages suggest rapid delivery of zircon from the arc to the basin via fluvial processes. In contrast, detrital zircon distributions from the foreland suggest a combination of fluvial and aerial transport. The presence of arc-derived zircon with diverse ages in the northern and southern foreland suggest a dominance of fluvial transport, where depocenters were located more proximal to arc sources. In contrast, an enrichment of syn-depositional zircon ages in the central foreland suggest aerial delivery via ash-fall to an area that was topographically isolated from the arc by high-standing hinterland terranes.

\section{Declaration of Competing Interest}

The authors declare that they have no known competing financial interests or personal relationships that could have appeared to influence the work reported in this paper.

\section{Acknowledgments}

This research was supported by the U.S. Geological Survey's National Cooperative Geologic Mapping (Schwartz, Colgan, Johnstone) and Mineral Resources (Holm-Denoma) Programs. Constructive reviews by Tomas Capaldi, Peter Copeland, Mihai Ducea, Jeremy Workman, and an anonymous reviewer enhanced the accuracy and clarity of this manuscript, as did discussions with Ryan Frazer, Karen Lund, Jens-Erik Lund Snee, Matt Malkowski, Kaleb Scarberry, Bob Schwartz, and Glenn Sharman. The authors also thank Adolph Yonkee and Arlo Weil for permission to reproduce components of their fig. 24 from Yonkee and Weil (2015). Compilations of in situ and detrital zircon U-Pb ages presented herein are included in the supplemental files and Schwartz (2021). Any use of trade, firm, or product names is for descriptive purposes only and does not imply endorsement by the U.S. Government.

\section{Appendix A. Supplementary data}

Supplementary data to this article can be found online at https://doi. org/10.1016/j.earscirev.2021.103734.

\section{References}

Ague, J.J., Brimhall, G.H., 1988. Magmatic arc asymmetry and distribution of anomalous plutonic belts in the batholiths of California: effects of assimilation, crustal thickness, and depth of crystallization. GSA Bull. 100 (6), 912-927.

Armstrong, R.L., 1988. Mesozoic and early Cenozoic magmatic evolution of the Canadian Cordillera. In: Clark, S.P., Burchfiel, B.C., Suppe, J. (Eds.), Processes in Continental Lithospheric Deformation: Geological Society of America Special Paper, 218, pp. 55-91.

Attia, S., Paterson, S.R., Cao, W., Chapman, A.D., Saleeby, J., Dunne, G.C., Stevens, C.H., Memeti, V., 2018. Late Paleozoic tectonic assembly of the Sierra Nevada prebatholithic framework and western Laurentian province links based on synthesized detrital zircon geochronology. In: Ingersoll, R.V., Lawton, T.F, Graham, S.A. (Eds.), Tectonics, Sedimentary Basins, and Provenance: A Celebration of William R. Dickinson's Career: GSA Special Paper, 540, pp. 267-295.

Attia, S., Cottle, J.M., Paterson, S.R., 2020. Erupted zircon record of continental crust formation during mantle driven arc flare-ups. Geology 48 (5), 446-451.

Barth, A.P., Schneiderman, J.S., 1996. A comparison of structures in the Andean orogen of northern Chile and exhumed midcrustal structures in southern California, USA: an analogy in tectonic style. Int. Geol. Rev. 38, 1075-1085.

Barth, A.P., Wooden, J.L., 2006. Timing of magmatism following initial convergence at a passive margin, southwestern U.S. Cordillera, and ages of lower crustal magma sources. J. Geol. 114, 231-245.

Barth, A.P., Wooden, J.L., Jacobsen, C.E., Probst, K., 2004. U-Pb geochronology and geochemistry of the McCoy Mountains Formation, southern California: a Cretaceous retroarc foreland basin. GSA Bull. 116 (1/2), 142-153. 
Barth, A.P., Wooden, J.L., Jacobsen, C.E., Economos, R.C., 2013. Detrital zircon as a proxy for tracking the magmatic arc system: the California arc example. Geology 41 (2), 223-226.

Barton, M.D., 1990. Cretaceous magmatism, metamorphism, and metallogeny in the east-central Great Basin, in Anderson, J.L., ed., The nature and origin of Cordilleran magmatism. GSA Memoir 174, 283-302.

Barton, M.D., Hanson, R.B., 1989. Magmatism and the development of low-pressure metamorphic belts: Implications from the western United States and thermal modeling. GSA Bull. 101, 1051-1065.

Bartschi, N.C., Saylor, J.E., Lapen, T.J., Blum, M.D., Pettit, B.S., Andrea, R.A., 2018. Tectonic controls on Late Cretaceous sediment provenance and stratigraphic architecture in the Book Cliffs, Utah. GSA Bull. 130 (11/12), 1763-1781.

Bateman, P.C., 1992. Plutonism in the central part of the Sierra Nevada batholith. In: U.S. Geological Survey Professional Paper, 1483, p. 186.

Berger, B., Hildebrand, T., O'Neill, J., 2011. Control of Precambrian basement deformation zones on emplacement of Laramide Boulder batholith and Butte mining district, Montana. In: U.S. Geological Survey Scientific Investigations Report 20115016 (29 pp.).

Bertucci, P.F., 1983. Petrology and provenance of the Stony Creek Formation, northwestern Sacramento Valley, California. In: Bertucci, P.F., Ingersoll, R.V. (Eds.), Guidebook to the Stony Creek Formation, Great Valley Group, Sacramento Valley, California: Los Angeles, Pacific Section, Society of Economic Paleontology and Mineralogy, pp. 1-16.

Beveridge, T.L., Roberts, E.M., Titus, A.L., 2020. Volcaniclastic member of the richly fossiliferous Kaiparowits Formation reveals new insights for regional correlation and tectonics in southern Utah during the latest. Cretaceous Research, Campanian. https://doi.org/10.1016/j.cretres.2020.104527.

Bilodeau, W.L., 1982. Tectonic models for Early Cretaceous rifting in southeastern Arizona. Geology 10, 466-470.

Bilodeau, W.L., 1986. The Mesozoic Mogollon highlands, Arizona: an Early Cretaceous rift shoulder. J. Geol. 94, 724-735.

Brandon, M.T., Cowan, D.S., Vance, J.A., 1988. The Late Cretaceous San Juan thrust system, San Juan Islands, 221. GSA Special Paper, Washington, p. 81.

Brooks, H.C., Ferns, M.L., Avery, D.G., 1984. Geology and gold deposits map of the Southwest Quarter of the Bates Quadrangle, Grant County, Oregon. In: Oregon Department of Geology and Mineral Industries Geologic Map Series, 35 scale 1: 24,000 .

Brown, E.H., 2012. Obducted nappe sequence in the San Juan Islands-northwest Cascade thrust system, Washington and British Columbia. Can. J. Earth Sci. 49, 796-817.

Burchfiel, B.C., Cowan, D.S., Davis, G.A., 1992. Tectonic overview of the Cordilleran orogen in the western United States. In: Burchfiel, B.C., Lipman, P.W., Zoback, M.L. (Eds.), The Cordilleran Orogen: Conterminous U.S.: Geological Society of America, The Geology of North America, G-3, pp. 407-480.

Busby-Spera, C.J., Mattinson, J.M., Riggs, N.R., Schermer, E.R., 1990. The TriassicJurassic magmatic arc in the Mojave-Sonoran Deserts and the Sierra-Klamath region; Similarities and differences in paleogeographic evolution. In: Harwood, D.S., Miller, M.M. (Eds.), Paleozoic and early Mesozoic paleogeographic relations; Sierra Nevada, Klamath Mountains, and related terranes: Boulder, Colorado, GSA Special Paper, 255, pp. 325-337.

Bush, M.A., Horton, B.K., Murphy, M.A., Stockli, D.F., 2016. Detrital record of initial basement exhumation along the Laramide deformation front, southern Rocky Mountains. Tectonics 35, 2117-2130.

Butler, R.F., Gehrels, G.E., McClelland, W.C., May, S.R., Klepacki, D., 1989. Discordant paleomagnetic poles from the Canadian Coast Plutonic Complex: regional tilt rather than large-scale displacement? Can. J. Geosci. 17, 691-694.

Butler, R.F., Gehrels, G.E., Kodama, K.P., 2001. A moderate translation alternative to the Baja British Columbia hypothesis. GSA Today 11 (6), 4-10.

Butler, R.F., Gehrels, G.E., Hart, W., Davidson, C., Crawford, M.L., 2006. Paleomagnetism of Late Jurassic to mid-Cretaceous plutons near Prince Rupert, British Columbia. In: Haggart, J.W., Enkin, R.J., Monger, J.W.H. (Eds.), Paleogeography of the North American Cordillera: Evidence For and Against LargeScale Displacements: Geological Association of Canada Special Paper, 46, pp. 171-200.

Capaldi, T.N., Horton, B.K., McKenzie, N.R., Stockli, D.F., Odlum, M.L., 2017. Sediment provenance in contractional orogens: The detrital zircon record from modern rivers in the Andean fold-thrust belt and foreland basin of western Argentina. Earth Planet. Sci. Lett. 479, 83-97.

Carrapa, B., DeCelles, P.G., Romero, M., 2019. Early inception of the Laramide orogeny in southwestern Montana and northern Wyoming: implications for models of flatslab subduction. J. Geophys. Res. 124, 2102-2123.

Cassel, E.J., Grove, M., Graham, S.A., 2012. Eocene drainage evolution and erosion of the Sierra Nevada batholith across northern California and Nevada. Am. J. Sci. 312, 117-144.

Cawood, P.A., Hawkesworth, C.J., Dhuime, B., 2012. Detrital zircon record and tectonic setting. Geology 40 (10), 875-878.

Cecil, M.R., Rotberg, G.L., Ducea, M.N., Saleeby, J.B., Gehrels, G.E., 2012. Magmatic growth and batholithic root development in the northern Sierra Nevada, California. Geosphere 8 (3), 592-606.

Cecil, M.R., Ferrer, M.A., Riggs, N.R., Marsaglia, K., Kylander-Clark, A., Ducea, M.N. Stone, P., 2019. Early arc development recorded in Permian-Triassic plutons of the northern Mojave Desert region, California, USA. GSA Bull. 131 (5/6), 749-765.

Chapin, C.E., 2012. Origin of the Colorado mineral belt. Geosphere 8 (1), 28-43.

Chapman, A.D., Saleeby, J.B., Wood, D.J., Piasecki, A., Kidder, S., Ducea, M.N., Farley, K. A., 2012. Late Cretaceous gravitational collapse of the southern Sierra Nevada batholith, California. Geosphere 8 (2), 314-341.
Coates, J.A., 1974. Geology of the Manning Park area, British Columbia. Geol. Surv. Can. Bull. 238 (177 pp.).

Colgan, J.P., Henry, C.D., 2009. Rapid middle Miocene collapse of the Mesozoic orogenic plateau in north-central Nevada. Int. Geol. Rev. 51 (9-11), 920-961.

Colgan, J.P., Dumitru, T.A., Reiners, P.W., Wooden, J.L., Miller, E.L., 2006. Cenozoic tectonic evolution of the Basin and Range Province in northwestern Nevada. Am. J. Sci. 306 (8), 616-654.

Colgan, J.P., John, D.A., Henry, C.D., Watts, K.E., 2018. Insights into the emplacement of upper-crustal plutons and their relationship to large silicic calderas, from field relationships, geochronology, and zircon trace element geochemistry in the Stillwater-Clan Alpine caldera complex, western Nevada, USA. J. Volcanol. Geotherm. Res. 349, 163-176.

Condie, K.C., Belousova, E., Griffin, W.L., Sircombe, K.N., 2009. Granitoid events in space and time: Constraints from igneous and detrital zircon age spectra. Gondwana Res. 15, 228-242.

Constenius, K.N., Johnson, R.A., Dickinson, W.R., Williams, T.A., 2000. Tectonic evolution of the Jurassic-Cretaceous Great Valley forearc, California: implications for the Franciscan thrust-wedge hypothesis. GSA Bull. 112, 1703-1723.

Copeland, P., 2020. On the use of geochronology of detrital grains in determining the time of deposition of clastic sedimentary strata. Basin Res. 32, 1532-1546.

Copeland, P., Currie, C.A., Lawton, T.F., Murphy, M.A., 2017. Location, location, location: The variable lifespan of the Laramide orogeny. Geology 45 (3), 223-226.

Coutts, D.S., Matthews, W.A., Englert, R.G., Brooks, M.D., Boivin, M.-P., Hubbard, S.M., 2020. Along-strike variations in sediment provenance within the Nanaimo basin reveal mechanisms of forearc basin sediment influx events. Lithosphere 12 (1), 180-197.

Davis, S.J., Dickinson, W.R., Gehrels, G.E., Spencer, J.E., Lawton, T.F., Carroll, A.R., 2009. The Paleogene California River: evidence of Mojave-Uinta paleodrainage from U-Pb ages of detrital zircons. Geology 38 (10), 931-934.

DeCelles, P.G., 1986. Sedimentation in a tectonically partitioned, nonmarine foreland basin: the Lower Cretaceous Kootenai Formation, southwestern Montana. GSA Bull. 97 (8), 911-931.

DeCelles, P.G., 1994. Late Cretaceous-Paleocene synorogenic sedimentation and kinematic history of the Sevier thrust belt, northeast Utah and southwest Wyoming. GSA Bull. 106, 32-56.

DeCelles, P.G., 2004. Late Jurassic to Eocene evolution of the Cordilleran thrust belt and foreland basin system, western USA. Am. J. Sci. 304, 105-168.

DeCelles, P.G., Coogan, J.C., 2006. Regional structure and kinematic history of the Sevier fold-and-thrust belt, central Utah. GSA Bull. 118 (7/8), 841-864.

DeCelles, P.G., Giles, K.A., 1996. Foreland basin systems. Basin Res. 8 (2), 105-123.

DeCelles, P.G., Graham, S.A., 2015. Cyclical processes in the North American Cordilleran orogenic system. Geology 43 (6), 499-502.

DeCelles, P.G., Ducea, M.N., Kapp, P., Zandt, G., 2009. Cyclicity in Cordilleran orogenic systems. Nature Geosci. 2, 251-257.

DeGraaff-Surpless, K., Graham, S.A., Wooden, J.L., McWilliams, M.O., 2002. Detrital zircon provenance analysis of the Great Valley Group, California: evolution of an arcforearc system. GSA Bull. 114 (12), 1564-1580.

DeGraaff-Surpless, K., Mahoney, J.B., Wooden, J.L., McWilliams, M.O., 2003. Lithofacies control in detrital zircon provenance studies: insights from the Cretaceous Methow basin, southern Canadian Cordillera. GSA Bull. 115 (8), 899-915.

Di Fiori, R.V., Long, S.P., Fetrow, A.C., Snell, K.E., Bonde, J.W., Vervoort, J., 2020. Syncontractional deposition of the Cretaceous Newark Canyon Formation, Diamond Mountains, Nevada: implications for strain partitioning within the U.S. Cordillera. Geosphere 16. https://doi.org/10.1130/GES02166.1.

Dickinson, W.R., 1981. Plate tectonics and the continental margin of California. In: Ernst, W.G. (Ed.), The geotectonic development of California. Prentice-Hall, Englewood Cliffs, New Jersey, pp. 1-28.

Dickinson, W.R., 1992. Cordilleran sedimentary assemblages. In: Burchfiel, B.C., Lipman, P.W., Zoback, M.L. (Eds.), The Cordilleran Orogen: Conterminous U.S.: Boulder, CO, Geological Society of America, The Geology of North America, G-3, pp. 539-551.

Dickinson, W.R., 1995. Forearc basins. In: Busby, C.J., Ingersoll, R.V. (Eds.), Tectonics of Sedimentary Basins. Blackwell Science, Cambridge, Massachusetts, pp. 221-261.

Dickinson, W.R., 2004. Evolution of the North American Cordillera. Ann. Rev. Earth Planet. Sci. 32, 13-44.

Dickinson, W.R., Gehrels, G.E., 2003. U-Pb ages of detrital zircons from Permian and Jurassic eolian sandstones of the Colorado Plateau, USA: paleogeographic implications. Sediment. Geol. 163, 29-66.

Dickinson, W.R., Gehrels, G.E., 2008. Sediment delivery to the Cordilleran foreland basin: Insights from U-Pb ages of detrital zircons in Upper Jurassic and Cretaceous strata of the Colorado Plateau. Am. J. Sci. 308, 1041-1082.

Dickinson, W.R., Gehrels, G.E., 2009a. U-Pb ages of detrital zircons in Jurassic eolian and associated sandstones of the Colorado Plateau: evidence for transcontinental dispersal and intraregional recycling of sediment. GSA Bull. 121 (3/4), 408-433.

Dickinson, W.R., Gehrels, G.E., 2009b. Use of U-Pb ages of detrital zircons to infer maximum depositional ages of strata: a test against a Colorado Plateau Mesozoic database. Earth Planet. Sci. Lett. 288 (1-2), 115-125.

Dickinson, W.R., Lawton, T.F., 2001. Tectonic setting and sandstone petrofacies of the Bisbee basin (USA-Mexico). J. South Am. Earth Sci. 14, 475-504.

Dickinson, W.R., Rich, E.I., 1972. Petrologic intervals and petrofacies in the Great Valley Sequence, Sacramento Valley, California. GSA Bull. 83, 3007-3024.

Dickinson, W.R., Seely, D.R., 1979. Structure and stratigraphy of forearc regions. AAPG Bull. $63,2-31$.

Dickinson, W.R., Snyder, W.S., 1978. Plate tectonics of the Laramide orogeny. In: Matthews, V. (Ed.), Laramide Folding Associated with Basement Block Faulting in the Western United States: Geological Society of America Memoir, 151, pp. 355-366. 
Dickinson, W.R., Suczek, C.A., 1979. Plate Tectonics and Sandstone Compositions. AAPG Bull. 63 (12), 2164-2182.

Dickinson, W.R., Vigrass, L.W., 1965. Geology of the Suplee-Izee Area, Crook Grant, and Harney Counties, Oregon, 58. Oregon Department of Geology and Mineral Industries Bulletin (109 pp.).

Dickinson, W.R., Helmold, K.P., Stein, J.A., 1979a. Mesozoic lithic sandstones in central Oregon. J. Sediment. Petrol. 49 (2), 501-516.

Dickinson, W.R., Ingersoll, R.V., Graham, S.A., 1979b. Paleogene sediment dispersal and paleotectonics in northern California. GSA Bull. 90 (part I), 897-898 part II, p 14581528.

Dickinson, W.R., Beard, L.S., Brakenridge, G.R., Erjavec, J.L., Ferguson, R.C., Inman, K. F., Knepp, R.A., Lindberg, F.A., Ryberg, P.T., 1983. Provenance of North American Phanerozoic sandstones in relation to tectonic setting. GSA Bull. 94, 222-235.

Dickinson, W.R., Hopson, C.A., Saleeby, J.B., 1996. Alternate origins of the Coast Range ophiolite (California): introduction and implications. GSA Today 6, 1-10.

Dickinson, W.R., Lawton, T.F., Gehrels, G.E., 2009. Recycling detrital zircons: a case study from the Cretaceous Bisbee Group of southern Arizona. Geology 37 (6), 503-506.

Dickinson, W.R., Lawton, T.F., Pecha, M., Davis, S.J., Gehrels, G.E., Young, R.A., 2012. Provenance of the Paleogene Colton Formation (Uinta Basin) and CretaceousPaleogene provenance evolution in the Utah foreland: Evidence from U-Pb ages of detrital zircons, paleocurrent trends, and sandstone petrofacies. Geosphere 8 (4), 854-880.

Dorsey, R.J., Lenegan, R.J., 2007. Structural controls on middle Cretaceous sedimentation in the Toney Butte area of the Mitchell inlier, Ochoco basin, central Oregon. In: Cloos, M., Calson, W.D., Gilbert, M.C., Liou, J.G., Sorenson, S.S. (Eds.), Convergent Margin Terranes and Associated Regions: A tribute to W.G. Ernst: GSA Special Paper, 419, pp. 97-115.

Druschke, P., Hanson, A.D., Wells, M.L., Gehrels, G.E., Stockli, D., 2011. Paleogeographic isolation of the Cretaceous to Eocene Sevier hinterland, east-central Nevada: Insights from U-Pb and (U-Th)/He detrital zircon ages of hinterland strata. GSA Bull. 123 (5/ 6), 1141-1160.

du Bray, E.A., Aleinikoff, J.N., Lund, K., 2012. Synthesis of petrographic, geochemical, and isotopic data for the Boulder batholith, southwest Montana. In: U.S. Geological Survey Professional Paper, 1793 (39 pp.).

Ducea, M., 2001. The California Arc: thick granitic batholiths, eclogitic residues, lithospheric-scale thrusting, and magmatic flare-ups. GSA Today 11 (11), 4-10.

Ducea, M.N., Barton, M.D., 2007. Igniting flare-up events in Cordilleran arcs. Geology 35, 1047-1050.

Ducea, M.N., Paterson, S.R., Gehrels, P.G., 2015a. High-volume magmatic events in subduction systems. Elements 11, 99-104.

Ducea, M.N., Saleeby, J.B., Bergantz, G., 2015b. The architecture, chemistry, and evolution of continental magmatic arcs. Ann. Rev. Earth Planet. Sci. 43, 299-331.

Dumitru, T.A., Wakabayashi, J., Wright, J.E., Wooden, J.L., 2010. Early Cretaceous transition from nonaccretionary behavior to strongly accretionary behavior within the Franciscan subduction complex. Tectonics 29, TC5001.

Dumitru, T.A., Ernst, W.G., Wright, J.E., Wooden, J.L., Wells, R.E., Farmer, L.P., Kent, A. J.R., Graham, S.A., 2013. Eocene extension in Idaho generated massive sediment floods into the Franciscan trench and into the Tyee, Great Valley, and Green River basins. Geology 41 (2), 187-190.

Dumitru, T.A., Ernst, W.G., Hourigan, J.K., McLaughlin, R.J., 2015. Detrital zircon U-Pb reconnaissance of the Franciscan subduction complex in northwestern California. Int. Geol. Rev. 57 (5-8), 767-800.

Dumitru, T.A., Elder, W.P., Hourigan, J.K., Chapman, A.D., Graham, S.A., Wakabayashi, J., 2016. Four Cordilleran paleorivers that connected Sevier thrust zones in Idaho to depocenters in California, Washington, Wyoming, and indirectly, Alaska. Geology 44 (1), 75-78.

Elder, W.P., 1988. Geometry of Upper Cretaceous bentonite beds: Implications about volcanic source areas and paleowind patterns, western interior, United States. Geology 16, 835-838.

Elliott, M.A., 1971. Stratigraphy and petrology of the Late Cretaceous rocks near Hilt and Hornbrook, Siskiyou County, California and Jackson County, Oregon [PhD thesis]. Oregon State University, Corvallis, Oregon, p. 171.

Engebretson, D.C., Cox, A., Gordon, R.G. (Eds.), 1985. Relative Motions Between Oceanic and Continental Plates in the Pacific Basin: GSA Special Paper, 206 (59 pp.).

England, T.D.J., Bustin, R.M., 1998. Architecture of the Georgia Basin southwestern British Columbia. Bull. Can. Petrol. Geol. 46 (2), 288-320.

Ernst, W.G., Snow, C.A., Scherer, H.H., 2008. Contrasting early and late Mesozoic petrotectonic evolution of northern California. GSA Bull. 120, 179-194.

Evernden, J.F., Kistler, R.W., 1970. Chronology of emplacement of Mesozoic batholith complexes in California and western Nevada. In: U.S. Geological Survey Professional Paper, 623, p. 42.

Fan, M., Carrapa, B., 2014. Late Cretaceous-early Eocene Laramide uplift, exhumation, and basin subsidence in Wyoming: crustal responses to flat slab subduction. Tectonics 33 (4), 509-529.

Finzel, E.S., Rosenblume, J.A., 2020. Dating lacustrine carbonate strata with detrital zircon U-Pb geochronology. Geology. https://doi.org/10.1130/G48070.1.

Folk, R.L., 1974. Petrology of Sedimentary Rocks: Hemphill Publishing Company. TX, Austin, p. 185.

Foreman, B.Z., Rogers, R.R., Deino, A.L., Wirth, K.R., Thole, J.T., 2008. Geochemical characterization of bentonite beds in the Two Medicine Formation (Campanian, Montana), including a new 40Ar/39Ar age. Cretaceous Res. 29 (3), 373-385.

Fosdick, J.C., Grove, M., Graham, S.A., Hourigan, J.K., Lovera, O., Romans, B.W., 2014 Detrital thermochronologic record of burial heating and sediment recycling in the Magallanes foreland basin, Patagonia. Basin Res. 27 (4), 546-572.
Friedman, R.M., Armstrong, R.L., 1995. Jurassic and Cretaceous geochronology of the southern Coast Belt, British Columbia, $49^{\circ}$ to $51^{\circ} \mathrm{N}$. In: Miller, D.M., Busby, C. (Eds.), Jurassic Magmatism and Tectonics of the North American Cordillera: Boulder, Colorado, GSA Special Paper, 299, pp. 95-139.

Fuentes, F., DeCelles, P.G., Gehrels, G.E., 2009. Jurassic onset of foreland basin deposition in northwestern Montana, USA: implications for along-strike synchroneity of Cordilleran orogenic activity. Geology 34 (4), 379-382.

Fuentes, F., DeCelles, P.G., Constenius, K.N., Gehrels, G.E., 2011. Evolution of the Cordilleran foreland basin system in northwestern Montana, U.S.A. GSA Bull. 123 (34), 507-533.

Fuentes, F., DeCelles, P.G., Constenius, K.N., 2012. Regional structure and kinematic history of the Cordilleran fold-thrust belt in northwestern Montana, USA. Geosphere 8 (5), 1104-1128.

Garber, K.L., Finzel, E.S., Pearson, D.M., 2020. Provenance of synorogenic foreland basin strata in southwestern Montana requires revision of existing models for Laramide tectonism: North American Cordillera. Tectonics 39. https://doi.org/10.1029/ 2019 TC005944.

Garver, J.I., 1992. Provenance of Albian-Cenomanian rocks of the Methow and Tyaughton basins, southern British Columbia: a mid-Cretaceous link between North America and the Insular terrane. Can. J. Earth Sci. 29 (6), 1274-1295.

Garver, J.I., Brandon, M.T., 1994. Fission-track ages of detrital zircons from Cretaceous strata, southern British Columbia: Implications for the Baja BC hypothesis. Tectonics 13, 401-420.

Garver, J.I., Davidson, C., 2015. Southwestern Laurentian zircons in the upper Cretaceous flysch of the Chugach-Prince William terrane in Alaska. Am. J. Sci. 315, 537-556.

Garzanti, E., 2019. Petrographic classification of sand and sandstone. Earth Sci. Rev. 192, 545-563.

Gaschnig, R.M., Vervoort, J.D., Lewis, R.S., McClelland, W.C., 2010. Migrating magmatism in the northern US Cordillera: in situ U-Pb geochronology of the Idaho batholith. Contrib. Mineral. Petrol. 159, 863-883.

Gaschnig, R.M., Vervoort, J.D., Lewis, R.S., Tikoff, B., 2011. Isotopic evolution of the Idaho batholith and Challis intrusive province, northern US Cordillera. J. Petrol. 52 (12), 2397-2429.

Gaschnig, R.M., Vervoort, J.D., Tikoff, B., Lewis, R.S., 2016. Construction and preservation of batholiths in the northern U.S. Cordillera. Lithosphere 9 (2), 315-324.

Gastil, R.G., 1975. Plutonic zones in the Peninsular Ranges of southern California and northern Baja California. Geology 3, 361-363.

Gehrels, G.E., 2012. Detrital zircon U-Pb geochronology: current methods and new opportunities. In: Busby, C., Azor, A. (Eds.), Tectonics of Sedimentary Basins: Recent advances: Oxford. Blackwell Publishing Ltd., UK, pp. 47-62.

Gehrels, G.E., 2014. Detrital zircon U-Pb geochronology applied to tectonics. Ann. Rev. Earth Planet. Sci. Lett. 41, 127-149.

Gehrels, G., Rusmore, M., Woodsworth, G., Crawford, M., Andronicos, C., Hollister, L., Patchett, J., Ducea, M., Butler, R., Klepeis, K., Davidson, C., Friedman, R. Haggard, J., Mahoney, B., Crawford, W., Pearson, D., Girardi, J., 2009. U-Th-Pb geochronology of the Coast Mountains batholith in north-coastal British Columbia: Constraints on age and tectonic evolution. GSA Bull. 121 (9/10), 1341-1361.

Gehrels, G.E., Blakey, R., Karlstrom, K.E., Timmons, J.M., Dickinson, W.R., Pecha, M., 2011. Detrital zircon U-Pb geochronology of Paleozoic strata in the Grand Canyon, Arizona. Lithosphere 3, 183-200.

Giorgis, S., Tikoff, B., McClelland, W., 2005. Missing Idaho arc: transpressional modification of the ${ }^{87} \mathrm{Sr}{ }^{86} \mathrm{Sr}$ transition on the western edge of the Idaho batholith.
mational Geology 33, 469-472.

Giorgis, S., McClelland, W., Fayon, A., Singer, B.S., Tikoff, B., 2008. Timing of deformation and exhumation in the western Idaho shear zone, McCall, Idaho. GSA Bull. 120, 1119-1133.

Girardi, J.D., Patchett, P.J., Ducea, M.N., Gehrels, G.E., Cecil, M.R., Rusmore, M.E., Woodsworth, G.J., Pearson, D.M., Manthei, C., Wetmore, P., 2012. Elemental and isotopic evidence for granitoid genesis from deep-seated sources in the Coast Mountains batholith, British Columbia. J. Petrol. 53 (7), 1505-1536.

Godfrey, N.J., Beaudoin, B.C., Klemperer, S.L., Levander, A.R., Leutgert, J.H., Meltzer, A. S., Mooney, W.D., Trehu, A.M., 1997. Ophiolitic basement to the Great Valley forearc basin, California, from seismic and gravity data: implications for crustal growth at the North American continental margin. GSA Bull. 109, 1526-1562.

Gonzales-Leon, C.M., McIntosh, W.C., Lozano-Santacruz, R., Valencia-Moreno, M., Amaya-Martinez, R., Rodriguez-Castañeda, J.L., 2000. Cretaceous and Tertiary sedimentary, magmatic, and tectonic evolution of north-central Sonora (Arizpe and Bacanuchi Quadrangles), northwest Mexico. GSA Bull. 112, 600-610.

Gonzales-Leon, C.M., Solari, L.A., Madhavaraju, J., 2017. Stratigraphy, geochronology and regional tectonic setting of the Late Cretaceous (ca. 82-70 Ma) Cabullona basin, Sonora, Mexico. J. South Am. Earth Sci. 80, 494-511.

Graham, S.A., Ingersoll, R.V., 1981. Field trip road log, Great Valley Group submarine fan facies and Sacramento Valley forearc gas province: Part I. Sacramento to Cache Creek and return. In: Graham, S.A. (Ed.), Field guide to the Mesozoic-Cenozoic convergent margin of northern California: Camarillo, California, AAPG Pacific Section, 50, pp. 71-78.

Graham, S.A., Stanley, R.G., Bent, J.V., Carter, J.B., 1989. Oligocene and Miocene paleogeography of central California and displacement along the San Andreas fault. GSA Bull. 101, 711-731.

Greene, A.R., Scoates, J.S., Weis, D., Katvala, E.C., Israel, S., Nixon, G.T., 2010. The architecture of oceanic plateaus revealed by the volcanic stratigraphy of the accreted Wrangellia oceanic plateau. Geosphere 6 (1), 47-73. 
Grieg, C.J., 1992. Jurassic and Cretaceous plutonic and structural styles of the Eagle Plutonic Complex, southwestern British Columbia, and their regional significance. Can. J. Earth Sci. 29 (4), 793-811.

Gromet, L.P., Silver, L.T., 1987. REE variations across the Peninsular Ranges batholith: Implications for batholithic petrogenesis and crustal growth in magmatic arcs. J. Petrol. 28, 75-125.

Grove, K., 1993. Latest Cretaceous basin formation within the Salinian terrane of westcentral California. GSA Bull. 105, 447-463.

Grove, M., Lovera, O., Harrison, M., 2003. Late Cretaceous cooling of the east-central Peninsular Ranges batholith $\left(33^{\circ} \mathrm{N}\right)$ : relationship to La Posta pluton emplacement, Laramide shallow subduction, and forearc sedimentation. In: Johnson, S.E., Paterson, S.R., Fletcher, J.M., Girty, G.H., Kimbrough, D.L., Martin-Barajas, M. (Eds.), Tectonic Evolution of Northwestern Mexico and Southwestern USA: GSA Special Paper, 374, pp. 355-397.

Haggart, J.W., 1986. Stratigraphy of the Redding Formation of north-central California and its bearing on Late Cretaceous paleogeography. In: Field Trip Guidebook-Pacific Section, 46. Society of Economic Paleontologists and Mineralogists, pp. 161-178.

Hamilton, W., Myers, W.B., 1967. The nature of batholiths. In: U.S. Geological Survey Professional Paper 554-C (30 pp.).

Hammarstrom, J.M., 1982. Chemical and mineralogical variation in the Pioneer batholith, southwest Montana. In: U.S. Geological Survey Open-File Report 82-148 (178 pp.).

Harlan, S.S., Geissman, J.W., Lageson, D.R., Snee, L.W., 1988. Paleomagnetic and isotopic dating of thrust-belt deformation along the eastern edge of the Helena Salient, northern Crazy Mountains Basin, Montana. GSA Bull. 100, 492-499.

Harwood, D.S., Helley, E.J., 1987. Late Cenozoic tectonism of the Sacramento Valley, California. In: U.S. Geological Survey Professional Paper 1359 (46 pp.).

Haugerud, R.A., Mahoney, J.B., Dragovitch, J.D., 1996. Geology of the Methow block: Northwest Geological Society, Fall Field Trip, Guidebook. Northwest Geological Society, Seattle, Washington (37 pp.).

Hawkesworth, C.J., Dhuime, B., Pietranik, A.B., Cawood, P.A., Kemp, A.I.S., Storey, C.D., 2010. The generation and evolution of the continental crust. J. Geol. Soc. Lond. 167, 229-248.

Henderson, L.J., Gordon, R.G., Engebretson, D.C., 1984. Mesozoic aseismic ridges on the Farallon plate and southward migration of shallow subduction during the Laramide orogeny. Tectonics 3, 121-132.

Hicks, J.F., Obradovich, J.D., Tauxe, L., 1999. Magnetostratigraphy, isotopic age calibration and intercontinental correlation of the Red Bird section of the Pierre Shale, Niobrara County, Wyoming, USA. Cretaceous Res. 20, 1-27.

Hicks, J.F., Johnson, K.R., Obradovich, J.D., Tauxe, L., Clark, D., 2002. Magnetostratigraphy and geochronology of the Hell Creek and basal Fort Union Formations of southwestern North Dakota and a recalibration of the CretaceousTertiary boundary. In: Hartman, J.H., Johnson, K.R., Nichols, D.J. (Eds.), The Hell Creek Formation and the Cretaceous-Tertiary boundary in the Northern Great Plains: An Integrated Continental Record of the End of the Cretaceous: GSA Special Paper 361, pp. 35-55.

Hill, M.L., 1985. Remarkable fossil locality: Crinoid stems from migmatite of the Coast Plutonic Complex, British Columbia. Geology 13, 825-826.

Hosford Scheirer, A., Magoon, L., 2007. Age, distribution, and stratigraphic relationship of rock units in the San Joaquin Basin province, California. In: Hosford Scheirer, A (Ed.), Petroleum Systems and Geologic Assessment of Oil and Gas in the San Joaquin Basin Province, California: U.S. Geological Survey Professional Paper 1713, pp. 2-107.

Housen, B.A., Beck Jr., M.E., 1999. Testing terrane transport: an inclusive approach to the Baja B.C. controversy. Geology 27 (12), 1143-1146.

Houston, R.A., Dilles, J.H., 2013. Structural geologic evolution of the Butte District, Montana. Econ. Geol. 108, 1397-1424.

Hurlow, H.A., 1993. Mid-Cretaceous strike-slip and contractional fault zones in the western intermontane terrane, Washington, and their relation to the North Cascadessoutheastern Coast Belt orogen. Tectonics 12, 1240-1257.

Ingersoll, R.V., 1979. Evolution of the Late Cretaceous forearc basin, northern and central California. GSA Bull. 90, 1813-1826.

Ingersoll, R.V., 1983. Petrofacies and provenance of Late Mesozoic forearc basin, northern and central California. AAPG Bull. 67 (7), 1125-1142.

Ingersoll, R.V., 2000. Models for origin and emplacement of Jurassic ophiolites of Northern California. In: Dilek, Y., Moores, E.M., Elthon, D., Nicolas, A. (Eds.), Ophiolites and Oceanic Crust: New Insights From Field Studies and the Ocean Drilling Program: GSA Special Paper 349, pp. 395-402.

Ingersoll, R.V., 2008. Subduction-related sedimentary basins of the USA Cordillera. In: Miall, A.D. (Ed.), The Sedimentary Basins of the United States and Canada: Amsterdam, Netherlands, Sedimentary Basins of the World, v. 5. Elsevier, pp. 395-428.

Ingersoll, R.V., 2019. Forearc strike-slip displacement as an alternative to subduction erosion, with examples from Mexico and California (sinistral Nacimiento fault). Can. J. Earth Sci. 56 (12), 1285-1296.

Ingersoll, R.V., Schweickert, R.A., 1986. A plate-tectonic model for Late Jurassic ophiolite genesis, Nevadan orogeny and forearc initiation, northern California. Tectonics 5 (6), 901-912.

Irving, E., Baker, J., Wright, N., Yorath, C.J., Enkin, R.J., York, D., 1995. Magnetism and age of the Porteau Pluton, southern Coast Belt, British Columbia: Evidence for tilt and translation. Can. J. Earth Sci. 32 (4), 380-392.

Irving, E., Wynne, P.J., Thorkelson, D.J., Schiarizza, P., 1996. Large (1000 to $4000 \mathrm{~km}$ ) northward movements of tectonic domains in the northern Cordillera, 83 to $45 \mathrm{Ma}$. J. Geophys. Res. 101, 17901-17916.

Irwin, W.P., 2003. Correlation of the Klamath Mountains and Sierra Nevada: U.S. Geological Survey Open-File Report 02-490, 1:1,000,000.
Jacobson, C.E., Grove, M., Pedrick, J.N., Barth, A.P., Marsaglia, K.M., Gehrels, G.E., Nourse, J.A., 2011. Late Cretaceous-early Cenozoic tectonic evolution of the southern California margin inferred from provenance of trench and forearc sediments. GSA Bull. 123 (3/4), 485-506.

Jiang, H., Lee, C.-T.A., 2017. Coupled magmatism-erosion in continental arcs: reconstructing the history of the Cretaceous Peninsular Ranges batholith, southern California through detrital hornblende barometry in forearc sediments. Earth Planet. Sci. Lett. 472, 69-81.

Jinnah, Z.A., Roberts, E.M., Deino, A.L., Larsen, J.S., Link, P.K., Fanning, C.M., 2009. New ${ }^{40} \mathrm{Ar}{ }^{39} \mathrm{Ar}$ and detrital zircon U-Pb ages for the Upper Cretaceous Wahweap and Kaiparowits formations on the Kaiparowits Plateau, Utah: implications for regional correlation, provenance, and biostratigraphy. Cretaceous Res. 30, 287-299.

Jones, D.L., 1960. Pelecypods of the genus Pterotrigonia from the west coast of the United States. J. Paleontol. 34, 433-439.

Jones, D.L., Murphy, M.A., Packard, E.L., 1965. The Lower Cretaceous (Albian) ammonite genera Leconteites and Brewericeras. In: U.S. Geological Survey Professional Paper 503-F (21 pp.).

Jones, D.L., Bailey, E.H., Imlay, R.W., 1969. Structural and stratigraphic significance of the Buchia zones in the Colyear Springs-Paskenta area, California. In: U.S. Geological Survey Professional Paper 647-A (21 pp.).

Kalakay, T.J., John, B.E., Lageson, D.R., 2001. Fault-controlled pluton emplacement in the Sevier fold-and-thrust belt of southwest Montana. J. Struct. Geol. 23, 1151-1165.

Katnick, D.C., Mustard, P.S., 2003. Geology of Denman and Hornby islands, British Columbia: Implications for Nanaimo basin evolution and formal definition of the Geoffrey and Spray formations, Upper Cretaceous Nanaimo Group. Can. J. Earth Sci. 40 (3), 375-393.

Kent, B.A.P., Dashtgard, S.E., Huang, C., MacEachern, J.A., Gibson, H.A., CathylHuhn, G., 2019. Initiation and early evolution of a forearc basin: Georgia Basin, Canada. Basin Res. https://doi.org/10.1111/bre.12378.

Kiessling, M.A., 1998. Provenance and Stratigraphic Correlation of the Mid-Cretaceous Pasayten Group, Northern Washington and Manning Provincial Park, British Columbia. MS thesis. Idaho State University, Pocatello, Idaho (148 pp.).

Kiessling, M.A., Mahoney, J.B., 1997. Revised stratigraphy of the Pasayten Group, Manning Park, British Columbia: geological survey of Canada. Curr. Res. 1997-A, $151-158$.

Kim, B.Y., Kodama, K.P., 2004. A compaction correlation for the paleomagnetism of the Nanaimo Group sedimentary rocks: implications for the Baja British Columbia hypothesis. J. Geophys. Res. 109 (B2), 1-17. B02102.

Kimbrough, D.L., Smith, D.P., Mahoney, J.B., Moore, T.E., Grove, M., Gastil, R.G., Ortega-Rivera, A., Manning, C.M., 2001. Forearc-basin sedimentary response to rapid Late Cretaceous batholith emplacement in the Peninsular Ranges of southern and Baja California. Geology 25 (6), 491-494.

Kistler, R.W., 1990. Two different lithosphere types in the Sierra Nevada, California. In: Anderson, J.L. (Ed.), The Nature and Origin of Cordilleran Magmatism, 174. Geological Society of America Memoir, Boulder, CO, pp. 271-281.

Kistler, R.W., Peterman, Z.E., 1978. Reconstruction of crustal blocks of California on the basis of initial Sr isotopic compositions of Mesozoic plutons. In: U.S. Geological Survey Professional Paper 1071 (27 pp.).

Kleinhans, L.C., Balcells-Baldwin, E.A., Jones, R.E., 1984. A paleogeographic reinterpretation of some middle Cretaceous units, north-central Oregon: evidence for a submarine turbidite system. In: Nilsen, T.H. (Ed.), Geology of the Upper Cretaceous Hornbrook Formation, Oregon and California, 42. Pacific Section SEPM, Book, Los Angeles, California, pp. 239-257.

Kleinspehn, K.L., 1985. Cretaceous sedimentation and tectonics, Tyaughton-Methow Basin, southwestern British Columbia. Can. J. Earth Sci. 22 (2), 154-174.

Klepper, M.R., Weeks, R.A., Ruppel, E.T., 1957. Geology of the southern Elkhorn Mountains, Jefferson and Broadwater Counties, Montana. In: U.S. Geological Survey Professional Paper 292 (82 pp.).

Klepper, M.R., Robinson, G.D., Smedes, H.W., 1971. On the nature of the Boulder batholith of Montana. GSA Bull. 82, 1563-1580.

Kodama, K.P., Ward, P.D., 2001. Compaction-corrected paleomagnetic paleo-latitudes for Late Cretaceous rudists along the Cretaceous California margin: evidence for less than $1500 \mathrm{~km}$ of post-Late Cretaceous offset for Baja British Columbia. GSA Bull. 113 (9), 1171-1178.

Krijgsman, W., Tauxe, L., 2006. E/I corrected paleolatitudes for the sedimentary rocks of the Baja British Columbia hypothesis. Earth Planet. Sci. Lett. 242, 205-216.

Kulik, D.M., Schmidt, C.J., 1988. Region of overlap and styles of interaction of Cordilleran thrust belt and Rocky Mountain foreland. In: Schmidt, C.J., Perry Jr., W. J. (Eds.), Interaction of the Rocky Mountain Foreland and the Cordilleran Thrust Belt, GSA Memoir 171, pp. 75-98.

Lageson, D.R., Schmitt, J.G., Horton, B.K., Kalakay, T.J., Burton, B.R., 2001. Influence of Late Cretaceous magmatism on the Sevier orogenic wedge, western Montana. Geology 29 (8), 723-726.

LaMaskin, T.A., 2012. Detrital zircon facies of Cordilleran terranes in western North America. GSA Today 22 (3), 4-11.

LaMaskin, T.A., Vervoort, J.D., Dorsey, R.J., Wright, J.E., 2011. Early Mesozoic paleogeography and tectonic evolution of the western United States: insights from detrital zircon U-Pb geochronology, Blue Mountains Province, northeastern Oregon. GSA Bull. 123 (9-10), 1939-1965.

Laskowski, A.K., DeCelles, P.G., Gehrels, G.E., 2013. Detrital zircon geochronology of Cordilleran retroarc foreland basin strata, western North America. Tectonics 32, 1027-1048.

Lawton, T.F., 2008. Laramide sedimentary basins. In: Hsu, K.J. (Ed.), Sedimentary Basins of the World: Volume 5. The Sedimentary Basins of the United States and Canada. Elsevier, The Netherlands, pp. 429-450. 
Lawton, T.F., Bradford, B.A., 2011. Correlation and provenance of Upper Cretaceous (Campanian) fluvial strata, Utah, U.S.A., from zircon U-Pb geochronology and petrography. J. Sediment. Res. 81, 495-512.

Lawton, T.F., McMillan, N.J., 1999. Arc abandonment as a cause for passive continental rifting: comparison to the Jurassic Borderland rift and the Cenozoic Rio Grande rift. Geology 27, 779-782.

Lawton, T.F., Hunt, G.J., Gehrels, G.E., 2010. Detrital zircon record of thrust belt unroofing in Lower Cretaceous synorogenic conglomerates, central Utah. Geology 38 (5), 463-466.

Lawton, T.F., Amato, J.M., Machin, S.E.K., Gilbert, J.C., Lucas, S.G., 2020. Transition from Late Jurassic rifting to middle Cretaceous dynamic foreland, southwestern U.S. and northwestern Mexico. GSA Bull. https://doi.org/10.1130/B35433.1.

Leary, R.J., Umhoefer, P., Smith, M.E., Riggs, N., 2017. A three-sided orogen: a new tectonic model for Ancestral Rocky Mountain uplift and basin development. Geology 45 (8), 735-738.

Lehman, T.M., 1991. Sedimentation and tectonism in the Laramide Tornillo basin of west Texas. Sediment. Geol. 75, 9-28.

Levy, D.A., Zuza, A.V., Haproff, P.J., Odlum, M.L., 2020. Early Permian tectonic evolution of the Last Chance thrust system: an example of induced subduction initiation along a plate boundary transform. GSA Bull. https://doi.org/10.1130/ B35752.1.

Li, L., Fan, M., 2018. Cenozoic sediment provenance in the northern Great Plains corresponds to four episodes of tectonic and magmatic events in the central North American Cordillera. Tectonics 37, 4018-4036.

Linn, A.M., DePaolo, D.J., Ingersoll, R.V., 1991. Nd-Sr isotopic provenance analysis of Upper Cretaceous Great Valley forearc sandstones. Geology 19, 803-806.

Lipman, P.W., 1984. The roots of ash flow calderas in western North America: windows into the tops of granitic batholiths. J. Geophys. Res. 89 (B10), 8801-8841.

Lipman, P.W., 1992. Magmatism in the Cordillera United States: progress and problems. In: Burchfiel, B.C., Lipman, P.W., Zoback, M.L. (Eds.), The Cordilleran Orogen: Conterminous U.S, G-3. Geological Society of America, The Geology of North America, Boulder, CO, pp. 481-514.

Little, S.W., 1986. Stratigraphy, Petrology, and Provenance of the Cretaceous Gable Creek Formation, Wheeler County, Oregon. MS thesis. Oregon State University, Corvallis, Oregon (133 pp.).

Livaccari, R.F., Burke, K., Sengor, A.M.C., 1981. Was the Laramide orogeny related to subduction of an oceanic plateau? Nature 289, 276-278.

Long, S.P., 2012. Magnitudes and spatial patterns of erosional exhumation in the Sevier hinterland, eastern Nevada and western Utah, USA: Insights from a Paleogene paleogeographic map. Geosphere 8 (4), 881-901.

Long, S.P., 2019. Geometry and magnitude of extension in the Basin and Range Province $\left(39^{\circ} \mathrm{N}\right)$, Utah, Nevada, and California, USA: constraints from a province-scale crosssection. GSA Bull. 131, 99-119.

Lovera, O.M., Grove, M., Kimbrough, D.L., Abbott, P.L., 1999. A method for evaluating basement exhumation histories from closure age distributions of detrital minerals. J. Geophys. Res. 104 (B12), 29419-29438.

Lund, K., 2008. Geometry of the Neoproterozoic and Paleozoic rift margin of western Laurentia: implications for mineral deposit settings. Geosphere 4, 429-444.

Lund, K., Snee, L.W., 1988. Metamorphism, structural development, and age of the continental-island arc juncture in west-central Idaho. In: Ernst, W.G. (Ed.), Metamorphism and Crustal Evolution, Western Conterminous United States. Prentice Hall, Englewood Cliffs, New Jersey, pp. 296-331.

Lund, K., Aleinikoff, J.N., Kunk, M.J., Unruh, D.M., Zeihen, G.D., Hodges, W.C., du Bray, E.A., O'Neill, J.M., 2002. SHRIMP U.Pb and ${ }^{40} \mathrm{Ar} /{ }^{39} \mathrm{Ar}$ age constraints for relating plutonism and mineralization in the Boulder batholith region, Montana. Econ. Geol. 97, 241-267.

Lund, K., Box, S.E., Holm-Denoma, C.S., San Juan, C.A., Blakely, R.J., Saltus, R.W., Anderson, E.D., DeWitt, E.H., 2015. Basement domain map of the conterminous United States and Alaska. In: U.S. Geological Survey Data Series, 898 (41 pp.).

Lynds, R.M., Xie, X., 2019. Detrital zircon geochronology of Upper Cretaceous to Paleocene sandstones from south-central Wyoming: evidence for Middle Campanian Laramide deformation. Tectonics 38, 4077-4098.

MacLaurin, C.I., Mahoney, J.B., Haggart, J.W., Goodin, J.R., Mustard, P.S., 2011. The Jackass Mountain Group of south-central British Columbia: depositional setting and evolution of an Early Cretaceous deltaic complex. Can. J. Earth Sci. 48 (6), 930-951.

Mahoney, J.B., Mustard, P.S., Haggart, J.W., Friedman, R.M., Fanning, C.M., McNicoll, V. J., 1999. Archean zircons in Cretaceous strata of the western Canadian Cordillera: the "Baja B.C." hypothesis fails a "crucial test". Geology 27 (3), 195-198.

Malkowski, M.A., Sharman, G.R., Johnstone, S.A., Grove, M.J., Kimbrough, D.L., Graham, S.A., 2019. Dilution and propagation of provenance trends in sand and mud: geochemistry and detrital zircon geochronology of modern sediment from central California (U.S.A.). Am. J. Sci. 319, 846-902.

Manduca, C.A., Kuntz, M.A., Silver, L.T., 1993. Emplacement and deformation history of the western margin of the Idaho batholith near McCall, Idaho: influence of a major terrane boundary. GSA Bull. 105 (6), 749-765.

Mansfield, C.F., 1979. Upper Mesozoic subsea fan deposits in the southern Diablo Range, California: record of the Sierra Nevada magmatic arc. GSA Bull. 90, I 1025-I 1046.

Martin, M.W., Clemens-Knott, D., 2015. Detrital-zircon record of the early Mesozoic southwestern Sierra Nevada arc preserved in Lower Cretaceous intra-arc and forearc deposits of central California, USA. In: Anderson, T.H., Didenko, A.N., Johnson, C.L., Khanchuk, A.I., MacDonald Jr., J.H. (Eds.), Late Jurassic Margin of Laurasia - A record of Faulting Accommodating Plate Rotation: GSA Special Paper, 513, pp. 269-284.

Matthews, W.A., Guest, B., Coutts, D., Bain, H., Hubbard, S., 2017. Detrital zircons from the Nanaimo basin, Vancouver Island, British Columbia: an independent test of Late Cretaceous to Cenozoic northward translation. Tectonics 36, 854-876.
May, S.R., Gray, G.G., Summa, L.L., Stewart, N.R., Gehrels, G.E., Pecha, M.E., 2013. Detrital zircon geochronology from the Bighorn Basin, Wyoming, USA: implications for tectonostratigraphic evolution and paleogeography. GSA Bull. 125 (9/10), 1403-1422.

McClelland, W.C., Tikoff, B., Manduca, C.A., 2000. Two-phase evolution of accretionary margins: examples from the North American Cordillera. Tectonophysics 326, 37-55.

McDowell, F.W., Foldan-Quintana, J., Connelly, J.N., 2001. Duration of Late Cretaceousearly Tertiary magmatism in east-central Sonora, Mexico. GSA Bull. 113, 521-531.

McKnight, B.K., 1964. A Stratigraphic Study of the Marine Cretaceous Rocks Near Mitchell, Oregon. MS thesis. Oregon State University, Corvallis, Oregon (80 pp.).

McKnight, B.K., 1971. Petrology and Sedimentation of Cretaceous and Eocene Rocks in the Medford-Ashland Region, southwestern Oregon. PhD thesis. Oregon State University, Corvallis, Oregon (177 pp.).

Merewether, E.A., Cobban, W.A., Obradovich, J.D., 2011. Biostratigraphic data from Upper Cretaceous formations - eastern Wyoming, central Colorado, and northeastern New Mexico. In: U.S. Geological Survey Scientific Investigations Map 3175, 2 Sheets, Pamphlet (10 pp.).

Merriam, J.C., 1901. A Contribution to the Geology of the John Day Basin, 2(9). Department of Geology, University of California Publications in Geological Sciences, pp. 269-314.

Miller, D.M., Nilsen, T.H., Bilodeau, W.L., 1992. Late Cretaceous to early Eocene geologic evolution of the U.S. Cordillera. In: Burchfiel, B.C., Lipman, P.W., Zoback, M.L. (Eds.), The Cordilleran Orogen: Conterminous U.S, G-3. Geological Society of America, The Geology of North America, Boulder, CO, pp. 205-260.

Mitchell, C., Graham, S.A., Suek, D.H., 2010. Subduction complex uplift and exhumation and its influence on Maastrichtian forearc stratigraphy in the Great Valley Basin, northern San Joaquin Valley, California. GSA Bull. 122, 2063-2078.

Monger, J.W.H., Price, R.A., Tempelman-Kluit, D.J., 1982. Tectonic accretion and the origin of the two major metamorphic and plutonic welts in the Canadian Cordillera. Geology 10, 70-75.

Monger, J.W.H., van der Hayden, P., Journeay, J.M., Evenchick, C.A., Mahoney, J.B., 1994. Jurassic-Cretaceous basins along the Canadian Coast Belt: their bearing on pre-mid-Cretaceous sinistral displacements. Geology 22, 175-178.

Moxon, I.W., 1990. Stratigraphic and Structural Architecture of the San JoaquinSacramento Basin. PhD thesis. Stanford University, Stanford, CA (371 pp.).

Mueller, P.A., Heatherington, A.L., D’Arcy, K.A., Wooden, J.L., Nutman, A.P., 1996. Contrasts between Sm-Nd whole-rock and U-Pb zircon systematics in the Tobacco Root batholith, Montana: implications for the determination of crustal age provinces. Tectonophysics 265, 169-179.

Mulcahy, S.R., Starnes, J.K., Day, H.W., Coble, M.A., Vervoort, J.D., 2018. Early onset of Franciscan subduction. Tectonics 37, 1194-1209.

Muller, J.E., Jeletzky, J.A., 1970. Geology of the Upper Cretaceous Nanaimo Group, Vancouver Island and Gulf Islands, British Columbia: Geological Survey of Canada Paper, 69-25 (84 pp.).

Mustard, P.S., 1994. The Upper Cretaceous Nanaimo Group, Georgia Basin. In: Monger, J.W.H. (Ed.), Geology and Geological Hazards of the Vancouver Region, Southwestern British Columbia: Geological Survey of Canada Bulletin, 481, pp. 27-95.

Mustard, P.S., Parrish, R.R., McNicoll, V., 1995. Provenance of the Upper Cretaceous Nanaimo Group, British Columbia: evidence from U-Pb analyses of detrital zircons. In: Dorobek, S.L., Ross, G.M. (Eds.), Stratigraphic Development in Foreland Basins: SEPM Special Publication, 52, pp. 112-127.

Myers, B.M., Brantley, S.R., 1995. Hazardous Phenomena at Volcanoes: U.S. Geological Survey Open-File Report 95-231 (2 pp.).

Nilsen, T.H., 1984. Stratigraphy, sedimentology, and tectonic framework of the Upper Cretaceous Hornbrook Formation, Oregon and California. In: Nilsen, T.H. (Ed.), Geology of the Upper Cretaceous Hornbrook Formation, Oregon and California: Los Angeles, California, Pacific Section SEPM, 42, pp. 51-88.

Nilsen, T.H., 1993. Stratigraphy of the Cretaceous Hornbrook Formation, Southern Oregon and Northern California. In: U.S. Geological Survey Professional Paper, 1521 (89 pp.).

Nilsen, T.H., Stewart, J.H., 1980. Penrose conference report; the Antler orogeny, midPaleozoic tectonism in western North America. Geology 8, 298-302.

Ojakangas, R.W., 1968. Cretaceous sedimentation, Sacramento Valley, California. GSA Bull. 79, 973-1008.

Oldow, J.S., 1983. Tectonic implications of a late Mesozoic fold and thrust belt in northwestern Nevada. Geology 11, 542-546.

Oldow, J.S., Bally, A.W., Ave Lallemant, H.G., Leeman, W., 1989. Phanerozoic evolution of the North American Cordillera, United States and Canada. In: Bally, A.W., Palmer, A.R. (Eds.), The Geology of North America: An Overview, A. Geological Society of America, The Geology of North America, Boulder, CO, pp. 139-232.

Oldow, J.S., Bartel, R.L., Gelber, A.W., 1990. Depositional setting and regional relationships of basinal assemblages: Pershing Ridge Group and Fencemaker Canyon sequence in northwestern Nevada. GSA Bull. 102, 193-222.

Orme, D.A., Surpless, K.D., 2019. The birth of a forearc: the basal Great Valley Group, California, USA. Geology 47 (8), 757-761.

Painter, C.S., Carrapa, B., DeCelles, P.G., Gehrels, G.E., Thomson, S.N., 2014. Exhumation of the North American Cordillera revealed by multi-dating of Upper Jurassic-Upper Cretaceous foreland basin deposits. GSA Bull. 126 (11/12), 1439-1464.

Paterson, S.R., Okaya, D., Memeti, V., Economos, R., Miller, R.B., 2011. Magma addition and flux calculations of incrementally constructed magma chambers in continental margin arcs: combined field, geochronologic, and thermal modeling studies. Geosphere 7, 1439-1468.

Pecha, M.E., Gehrels, G.E., Karlstrom, K.E., Dickinson, W.R., Donahue, M.S., Gonzales, D. A., Blum, M.D., 2018. Provenance of Cretaceous through Eocene strata of the Four 
Corners region: insights from detrital zircons in the San Juan Basin, New Mexico and Colorado. Geosphere 14 (2), 785-811.

Pessagno Jr., E.A., 1977. Upper Jurassic Radiolaria and radiolarian biostratigraphy of the California Coast Ranges. Micropaleontology 23, 56-113.

Pettit, B.S., Blum, M., Pecha, M., McLean, N., Bartschi, N.C., Saylor, J.E., 2019. Detritalzircon $\mathrm{U}-\mathrm{Pb}$ paleodrainage reconstruction and geochronology of the Campanian Blackhawk-Castlegate succession, Wasatch Plateau and Book Cliffs, Utah. J. Sediment. Res. 89 (4), 273-292.

Poole, F.G., Steward, J.H., Palmer, A.R., Sandberg, C.A., Madrid, R.J., Ross Jr., R.J., Hintze, L.F., Miller, M.M., Wrucke, C.T., 1992. Latest Precambrian to latest Devonian time; development of a continental margin. In: Burchfiel, B.C., Lipman, P.W., Zoback, M.L. (Eds.), The Cordilleran Orogen: Conterminous U.S, G-3. Geological Society of America, The Geology of North America, Boulder, CO, pp. 9-56.

Premo, W.R., Morton, D.M., Wooden, J.L., Manning, C.M., 2014. U-Pb zircon geochronology of plutonism in the northern Peninsular Ranges batholith, southern California: implications for the Late Cretaceous tectonic evolution of southern California. In: Morton, D.M., Miller, F.K. (Eds.), Peninsular Ranges Batholith, Baja California and Southern California: GSA Memoir, 211, pp. 145-180.

Pujols, E.J., Stockli, D.F., Constenius, K.N., Horton, B.K., 2020. Thermochronological and geochronological constraints on Late Cretaceous unroofing and proximal sedimentation in the Sevier orogenic belt, Utah. Tectonics 39. https://doi.org/ 10.1029/2019TC005794.

Quinn, G.M., Hubbard, S.M., Putnam, P.E., Matthews, W.A., Daniels, B.G., Guest, B. 2018. A Late Jurassic to Early Cretaceous record of orogenic wedge evolution in the Western Interior basin, USA and Canada. Geospheres 14 (3), 1187-1206.

Riggs, N.R., Reynolds, S.J., Lindner, P.J., Howell, E.R., Barth, A.P., Parker, W.G., Walker, J.D., 2013. The Early Mesozoic Cordilleran arc and Late Triassic paleogeography: the detrital record in Upper Triassic sedimentary successions on and off the Colorado Plateau. Geosphere 9 (3), 602-613.

Riggs, N.R., Oberling, Z.A., Howell, E.R., Parker, W.G., Barth, A.P., Cecil, M.R., Martz, J. W., 2016. Sources of volcanic detritus in the basal Chinle Formation, southwestern Laurentia, and implications for the Early Mesozoic magmatic arc. Geosphere 12 (2), 439-463.

Riggs, N.R., Sanchez, T.B., Reynolds, S.J., 2020. Evolution of the early Mesozoic Cordilleran arc: the detrital zircon record of back-arc basin deposits, Triassic Buckskin Formation, western Arizona and southeastern California, USA. Geosphere 16 (4), 1042-1057.

Robinson Roberts, L.N., Kirschbaum, M.A., 1995. Paleogeography of the Late Cretaceous of the western interior of Middle North America - coal distribution and sediment accumulation. In: U.S. Geological Survey Professional Paper, 1561 (115 pp.).

Robinson, G.D., Klepper, M.R., Obradovich, J.D., 1968. Overlapping plutonism, volcanism, and tectonism in the Boulder batholith region, western Montana. In: GSA Memoir, 116, pp. 557-576.

Rogers, R.R., Swisher III, C.C., Horner, J.R., 1993, 40Ar/39Ar age and correlation of the nonmarine Two Medicine Formation (Upper Cretaceous), northwestern Montana, U. S.A. Can. J. Earth Sci. 30, 1066-1075.

Ronemus, C.B., Orme, D.A., Campbell, S., Black, S.R., Cook, J., 2020. MesoproterozoicEarly Cretaceous provenance and paleogeographic evolution of the Northern Rocky Mountains: Insights from the detrital zircon record of the Bridger Range, Montana, USA. GSA Bull. https://doi.org/10.1130/B35628.1.

Rusmore, M.E., Potter, C.J., Umhoefer, P.J., 1988. Middle Jurassic terrane accretion along the western edge of the Intermontane superterrane, southwest British Columbia. Geology 16, 891-894.

Rusmore, M.E., Woodsworth, G.J., Gehrels, G.E., 2005. Two-stage exhumation of midcrustal arc rocks, Coast Mountains, British Columbia. Tectonics 24 (TC5013), $1-25$.

Rusmore, M.E., Bogue, S.W., Woodsworth, G.J., 2013. Paleogeography of the Insular and Intermontane terranes reconsidered: evidence from the southern Coast Mountains Batholith, British Columbia. Lithosphere 5, 521-536.

Saleeby, J.B., 1990. Progress in tectonic and petrogenic studies in an exposed cross section of young $(\sim 100 \mathrm{Ma})$ continental crust, southern Sierra Nevada, California. In: Salisbury, M.H., Fountain, D.M. (Eds.), Exposed Crustal Sections of the Continental Crust. Kluwer Academic, Norwell, Massachusetts, pp. 137-158.

Saleeby, J.B., 1996. Coast range ophiolite as parautochthonous forearc lithosphere. GSA Today 6 (2), 6-8.

Saleeby, J., 2003. Segmentation of the Laramide slab-Evidence from the southern Sierra Nevada region. GSA Bull. 115, 655-668.

Saleeby, J., Dunne, G., 2015. Temporal and tectonic relations of early Mesozoic arc magmatism, southern Sierra Nevada, California. In: Anderson, T.H., Didenko, A.N., Johnson, C.L., Khanchuk, A.I., MacDonald Jr., J.H. (Eds.), Late Jurassic Margin of Laurasia - A Record of Faulting Accommodating Plate Rotation: GSA Special Paper, 513, pp. 223-268.

Saleeby, J., Farley, K.A., Kistler, R.W., Fleck, R., 2007. Thermal evolution and exhumation of deep-level batholithic exposures, southernmost Sierra Nevada, California. In: Cloose, M., Carlson, W.D., Gilbert, M.C., Liou, J.G., Sorensen, S.S. (Eds.), Convergent Margin Terranes and Associated Regions: A Tribute to W.G. Ernst: GSA Special Paper, 419, pp. 39-66.

Scarberry, K.C., Yakovlev, P.V., Schwartz, T.M., 2020. Mesozoic magmatism in Montana In: Metesh, J.J., Vuke, S.M. (Eds.), Geology of Montana-Geologic History: Montana Bureau of Mines and Geology Special Publication 122, 1 (30 pp.).

Schmandt, B., Humpreys, E., 2011. Seismically imaged relict slab from the 55 Ma Siletzia accretion to the northwest United States. Geology 39, 175-178.

Schmidt, C.J., Garihan, J.M., 1983. Laramide tectonic development of the Rocky Mountain foreland of southwestern Montana. In: Lowell, J. (Ed.), Rocky Mountain Foreland Basins and Uplifts. Rocky Mountain Association of Geologists, Denver, Colorado, pp. 271-294.
Schmidt, C.J., O'Neill, J.M., 1982. Structural evolution of the southwestern Montana transverse zone. In: Powers, R.B. (Ed.), Geologic Studies of the Cordilleran Thrust Belt. Rocky Mountain Association of Geologists, Denver, Colorado, pp. 193-218.

Schmidt, M.W., Poli, S., 2004. Magmatic epidote. Rev. Mineral. Geochem. 56 (1), 399-430.

Schmidt, C.J., O'Neill, J.M., Brandon, W.C., 1988. Influence of Rocky Mountain foreland uplifts on the development of the frontal fold and thrust belt, southwestern Montana. In: Schmidt, C.J., Perry Jr., W.J. (Eds.), Interaction of the Rocky Mountain Foreland and the Cordilleran Thrust Belt: GSA Memoir, 171, pp. 171-201.

Schmidt, K.L., Wetmore, P.H., Alsleben, H., Paterson, S.R., 2014. Mesozoic tectonic evolution of the southern Peninsular Ranges batholith, Baja California, Mexico: longlived history of a collisional segment in the Mesozoic Cordilleran arc. In: Morton, D. M., Miller, F.K. (Eds.), Peninsular Ranges Batholith, Baja California and Southern California: GSA Memoir, 211, pp. 645-668.

Schwartz, T.M., 2021. Compilation of in situ and detrital zircon U-Pb ages for the Jurassic-Paleocene North American Cordillera (28-50 degrees north). In: U.S. Geological Survey Data Release. https://doi.org/10.5066/P9E5INN9.

Schwartz, R.K., DeCelles, P.G., 1988. Foreland basin evolution and synorogenic sedimentation in response to interactive Cretaceous thrusting and reactivated foreland partitioning. In: Schmidt, C.J., Perry Jr., W.J. (Eds.), Interaction of the Rocky Mountain Foreland and the Cordilleran Thrust Belt: GSA Memoir, 171, pp. 489-513.

Schwartz, T.M., Schwartz, R.K., 2013. Paleogene post-compressional intermontane basin evolution along the frontal Cordilleran fold-and-thrust belt of southwestern Montana. GSA Bull. 125, 961-984.

Schwartz, R.K., Vuke, S.M., 2019. Estuarine deposits in the Kootenai Formation as evidence of an Early Cretaceous (pre-Albian) marine advance into western Montana and relationship to Cordilleran foreland basin evolution. In: Montana Bureau of Mines and Geology Memoir, 69 (88 pp.).

Schwartz, T.M., Methner, K., Mulch, A., Graham, S.A., Chamberlain, C.P., 2019a. Paleogene topographic and climatic evolution of the Northern Rocky Mountains from integrated sedimentary and isotopic data. GSA Bull. 131 (7/8), 1203-1223.

Schwartz, T.M., Schwartz, R.K., Weislogel, A.L., 2019b. Orogenic recycling of detrital zircons characterizes age distributions of North American Cordilleran strata. Tectonics 38, 4320-4334.

Schweickert, R.A., 2015. Jurassic evolution of the Western Sierra Nevada metamorphic province. In: Anderson, T.H., Didenko, A.N., Johnson, C.L., Khanchuk, A.I., MacDonald Jr., J.H. (Eds.), Late Jurassic Margin of Laurasia - A Record of Faulting Accommodating Plate Rotation: GSA Special Paper, 513, pp. 299-358.

Schweickert, R.A., Cowan, D.S., 1975. Early Mesozoic tectonic evolution of the western Sierra Nevada, California. GSA Bull. 86, 1329-1336.

Seiders, V.M., 1983. Correlation and provenance of upper Mesozoic chert-rich conglomerate of California. GSA Bull. 94, 875-888.

Sharman, G.R., Graham, S.A., Grove, M., Kimbrough, D.L., Wright, J.E., 2015. Detrita zircon provenance of the Late Cretaceous-Eocene California forearc: influence of Laramide low-angle subduction on sediment dispersal and paleogeography. GSA Bull. $127(1 / 2), 38-60$.

Sharman, G.R., Sharman, J.P., Sylvester, Z., 2018a. detritalPy: a Python-based toolset for visualizing and analyzing detrital geo-thermochronologic data. Deposit. Rec. 4, 202-215.

Sharman, G.R., Stockli, D.F., Flaig, P.G., Raynolds, R.G., Covault, J.A., 2018b. Local-todistant provenance cyclicity of the southern Front Range, central Colorado: insights from detrital zircon geochronology. In: Ingersoll, R.V., Lawton, T.F., Graham, S.A. (Eds.), Tectonics, Sedimentary Basins, and Provenance: A Celebration of William R. Dickinson's Career: GSA Special Paper, 540. https://doi.org/10.1130/2018.2540 (24).

Shervais, J.W., 2001. Birth, death, and resurrection: the life cycle of suprasubduction zone ophiolites. Geochem. Geophys. Geosyst. 2, 1010.

Short, P.F., Ingersoll, R.V., 1990. Petrofacies and provenance of the Great Valley Group, southern Klamath Mountains and northern Sacramento Valley. In: Ingersoll, R.V., Nilsen, T.H. (Eds.), Scaramento Valley Symposium and Guidebook, 65. Pacific Section SEPM, Upland, CA, pp. 39-52.

Silver, L.T., Chappell, B.W., 1988. The Peninsular Ranges Batholith: an insight into the evolution of the Cordilleran batholiths of southwestern North America. Trans. R. Soc. Edinburgh 79 (2-3), 105-121.

Singer, B.S., Jicha, B.R., Sawyer, D., Walaszczyk, I., Buchwaldt, R., Mutterlose, J., 2020. Geochronology of late Albian-Cenomanian strata in the U.S. Western Interior. GSA Bull. https://doi.org/10.1130/B35794.1.

Smedes, H., 1973. Regional geologic setting of the Boulder batholith, Montana. In: Miller, R. (Ed.), Guidebook fro the Butte field meeting of the Society of Economic Geologists. The Anaconda Company, Butte, Montana, pp. A-1-A-6.

Snee, L.W., Lund, K., Sutter, J.G., Balcer, D.E., Evans, K.V., 1995. An ${ }^{40} \mathrm{Ar} /{ }^{39} \mathrm{Ar}$ chronicle of the tectonic development of the Salmon River suture zone, western Idaho. In: Vallier, T.L., Brooks, H.C. (Eds.), Geology of the Blue Mountains Region of Oregon, Idaho, and Washington: Petrology and Tectonic Evolution of Pre-Tertiary Rocks of the Blue Mountains Region: U.S. Geological Survey Professional Paper, 1438, pp. 359-414.

Snell, K.E., Koch, P.L., Druschke, P., Foreman, B.Z., Eiler, J.M., 2014. High elevation of the 'Nevadaplano' during the Late Cretaceous. Earth Planet. Sci. Lett. 386, 52-63.

Spencer, J.E., Richard, S.M., Gehrels, G.E., Gleason, J.D., Dickinson, W.R., 2011. Age and tectonic setting of the Mesozoic McCoy Mountains Formation in western Arizona, USA. GSA Bull. 123 (7/8), 1258-1274.

Squires, R.L., Saul, L.R., 2002. New early Late Cretaceous (Cenomanian) mollusks from Oregon. J. Paleontol. 76, 43-51.

Stein, H.J., Crock, J.G., 1990. Late Cretaceous-Tertiary magmatism in the Colorado Mineral Belt; rare earth element and samarium-neodymium isotopic studies. In: 
Anderson, J.L. (Ed.), The Nature and Origin of Cordilleran Magmatism: GSA Memoir, 174, pp. 195-224.

Stroup, C.N., Link, P.K., Janecke, S.U., Fanning, C.M., Yaxley, G.M., Beranek, L.P., 2008. Eocene to Oligocene provenance and drainage in extensional basins of southwest Montana and east-central Idaho: evidence from detrital zircon populations in the Renova Formation and equivalent strata. In: Spencer, J.E., Titley, S.R. (Eds.), Ores and Orogenesis: Circum-Pacific Tectonics, Geologic Evolution, and Ore Deposits: Arizona Geological Society Digest, 22, pp. 529-546.

Suchecki, R.K., 1984. Facies history of the Upper Jurassic-Lower Cretaceous Great Valley Sequence; response to structural development of an outer-arc basin. J. Sediment. Petrol. 54, 170-191.

Surpless, K.D., 2014. Geochemistry of the Great Valley Group: an integrated provenance record. Int. Geol. Rev. 57 (5-8), 747-766.

Surpless, K.D., Beverly, E.J., 2013. Understanding a critical basinal link in Cretaceous Cordilleran paleogeography: detailed provenance of the Hornbrook Formation, Oregon and California. GSA Bull. 125 (5/6), 709-727.

Surpless, K.D., Gulliver, K.D.H., 2018. Provenance analysis of the Ochoco basin, central Oregon: a window into the Late Cretaceous paleogeography of the northern U.S. Cordillera. In: Ingersoll, R.V., Graham, S.A., Lawton, T.F. (Eds.), Tectonics, Sedimentary Basins, and Provenance: A Celebration of William R. Dickinson's Career: GSA Special Paper, 540. https://doi.org/10.1130/2018.2540(11).

Surpless, K.D., Graham, S.A., Covault, J.A., Wooden, J.L., 2006. Does the Great Valley Group contain Jurassic strata? Reevaluation of the age and early evolution of a classic forearc basin. Geology 34 (1), 21-24.

Surpless, K.D., Sickmann, Z.T., Koplitz, T.A., 2014. East-derived strata in the Methow basin record rapid mid-Cretaceous uplift of the southern Coast Mountains batholith. Can. J. Earth Sci. 51, 339-357.

Surpless, K.D., Clemens-Knott, D., Barth, A.P., Gevedon, M., 2019. A survey of Sierra Nevada magmatism using Great Valley detrital zircon trace-element geochemistry: view from the forearc. Lithosphere 11 (5), 603-619.

Szwarc, T.S., Johnson, C.L., Stright, L.E., McFarlane, C.M., 2015. Interactions between axial and transverse drainage systems in the Late Cretaceous Cordilleran foreland basin: evidence from detrital zircons in the Straight Cliffs Formation, southern Utah, USA. GSA Bull. 127 (3/4), 372-392.

Talling, P.J., Lawton, T.F., Burbank, D.W., Hobbs, R.S., 1995. Evolution of the latest Cretaceous-Eocene nonmarine deposystems in the Axhandle piggyback basin of central Utah. GSA Bull. 107, 297-315.

Tennyson, M.E., Cole, M.R., 1978. Tectonic significance of upper Mesozoic Pasayten sequence, northeastern Cascade Range, Washington and British Columbia. In: Howell, A.G., McDougall, K. (Eds.), Mesozoic Paleogeography of the Western United States. Pacific Section SEPM, Los Angeles, California, pp. 499-508.

Thayer, T.P., Brown, C.E., 1966. Geologic Map of the Aldrich Mountain Quadrangle: U.S. Gological Survey Map GQ-438, scale 1:62,500.

Thompson, G.G., Yett, J.R., Green, K.E., 1984. Subsuface Stratigraphy of the Ochoco Basin, 8. Oregon Department of Geology and Mineral Industries, Oil and Gas Investigations, Oregon (18 pp.).

Tilling, R.I., 1974. Composition and time relations of plutonic and associated volcanic rocks, Boulder batholith region, Montana. GSA Bull. 85, 1925-1930.

Tilling, R.I., Klepper, M.R., Obradovich, J.D., 1968. K-Ar ages and time span of emplacement of the Boulder Batholith, Montana. Am. J. Sci. 266, 671-689.

Todd, V.R., Shaw, S.E., 1985. S-type granitoids in an I-S line in the Peninsular Ranges batholith, southern California. Geology 13, 231-233.

Trexler Jr., J.H., Bourgeois, J., 1985. Evidence for Mid-Cretaceous Wrench Faulting in the Methow Basin, Washington: tectonostratigraphic setting of the Virginia Ridge Formation. Tectonics 4, 379-394.

Unruh, D.M., Lund, K., Kuntz, M.A., Snee, L.W., 2008. Uranium-lead zircon ages and Sr, $\mathrm{Nd}$, and $\mathrm{Pb}$ isotope geochemistry of selected plutonic rocks from western Idaho. In: U.S. Geological Survey Open-File Report 2008-1142 (37 pp.).

Van Buer, N.J., Miller, E.L., Dumitru, T.A., 2009. Early Tertiary paleogeographic map of the northern Sierra Nevada batholith and the northwestern Basin and Range. Geology 37 (4), 371-374. van de Kamp, P.G., Leake, B.E., 2011. Petrography and geochemistry of feldspathic and mafic sediments of the northeastern Pacific Margin. Earth Environ. Sci. Trans. R. Soc. Edinburgh 76 (4), 411-449.

van der Heyden, P., 1992. A Middle Jurassic to early Tertiary Andean-Sierran arc model for the Coast belt of British Columbia. Tectonics 11, 82-97.

Vuke, S.M., 2020. Synorogenic basin deposits and associated Laramide uplifts in the Montana part of the Cordilleran foreland basin system. In: Metesh, J.J., Vuke, S.M. (Eds.), Geology of Montana-Geologic History: Montana Bureau of Mines and Geology Special Publication 122, 1 (39 pp.).

Wakabayashi, J., 1992. Nappes, tectonics, of oblique plate convergence, and metamorphic evolution related to 140 million years of continuous subduction, Franciscan Complex, California. J. Geol. 100, 19-40.

Wakabayashi, J., 2015. Anatomy of a subduction complex: Architecture of the Franciscan Complex, California, at multiple length and time scales. Int. Geol. Rev. 57, 669-746.

Ward, P.D., Hurtado, J.M., Kirschvink, J.L., Verosub, K.L., 1997. Measurements of the Cretaceous paleolatitude of Vancouver Island:consistent with the Baja-British Columbia hypothesis. Science 277, 1642-1645.

Watson, E.B., Harrison, T.M., 1983. Zircon saturation revisited: temperature and composition effects in a variety of crustal magma types. Earth Planet. Sci. Lett. 64 (2), 295-304.

Weil, A.B., Yonkee, W.A., 2012. Layer-parallel shortening across the Sevier fold-thrust belt and Laramide foreland of Wyoming: spatial and temporal evolution of a complex geodynamic system. Earth Planet. Sci. Lett. 357-358, 405-420.

Wells, M.L., Hoisch, T.D., Cruz-Uribe, A.M., Vervoort, J.D., 2012. Geodynamics of synconvergent extension and tectonic mode-switching: constraints from the SevierLaramide orogen. Tectonics 31, TC1002. https://doi.org/10.1029/2011TC002913.

Weltje, G.J., 2006. Ternary sandstone composition and provenance: an evaluation of the 'Dickinson model'. In: Buccianti, A., Mateu-Figueras, G., Pawlowsky-Glahn, V. (Eds.), Compositional Data Analysis in the Geosciences: From Theory to Practice: Geological Society, London, Special Publications, 264, pp. 79-99.

Whitmeyer, S.J., Karlstrom, K.E., 2007. Tectonic model for the Proterozoic growth of North America. Geosphere 3, 220-259.

Williams, T.A., 1997. Basin-fill Architecture and Forearc Tectonics: Cretaceous Great Valley Group, Sacramento Basin, Northern California. PhD thesis. Stanford University, Stanford, CA (412 pp.).

Williams, T.A., Graham, S.A., 2013. Controls on forearc basin architecture from seismic and sequence stratigraphy of the Upper Cretaceous Great Valley Group, central Sacramento Basin, California. Int. Geol. Rev. 55, 2030-2059.

Woodsworth, G.J., 1979. Metamorphism, deformation, and plutonism in the Mount Raleigh pendant, Coast Mountains, British Columbia. Can. Geol. Surv. Bull. 295 (58 pp.).

Wyld, S.J., 2002. Structural evolution of a Mesozoic backarc fold-and-thrust belt in the U. S. Cordillera: New evidence from northern Nevada. GSA Bull. 114 (11), 1452-1468.

Wyld, S.J., Umhoefer, P.J., Wright, J.E., 2006. Reconstructing northern Cordilleran terranes along known Cretaceous and Cenozoic strike-slip faults: Implications for the Baja British Columbia hypothesis and other models. In: Geological Association of Canada Special Paper 46, pp. 277-298.

Wynne, P.J., Irving, E., Maxson, J.A., Kleinspehn, K.L., 1995. Paleomagnetism of the Upper Cretaceous strata of Mount Tatlow: evidence for $3000 \mathrm{~km}$ of northward displacement of the eastern Coast Belt, British Columbia. J. Geophys. Res. 100 (B4), 6073-6091.

Yonkee, W.A., Weil, A.B., 2015. Tectonic evolution of the Sevier and Laramide belts within the North American Cordillera orogenic system. Earth Sci. Rev. 150, 531-593.

Zen, E., 1996. Plutons in the eastern part of the Pioneer batholith: field relations and petrographic descriptions. In: U.S. Geological Survey Open-File Report 96-97 (98 pp.).

Zen, E., Hammarstrom, J.M., 1984. Magmatic epidote and its petrologic significance. Geology 12 (9), 515-518. 